\title{
Viscosity, Electrical Conductivity, and Cesium Volatility of ORNL Vitrified Soils with Limestone and Sodium Additives
}

\author{
J. W. Shade \\ G. F. Piepel
}

May 1990

Prepared for the U.S. Department of Energy under Contract DE-AC06-76RLO 1830

Pacific Northwest Laboratory

Operated for the U.S. Department of Energy

by Battelle Memorial Institute 


\title{
DISCLAIMER
}

This report was prepared as an account of work sponsored by an agency of the United States Government. Neither the United States Government nor any agency thereof, nor Battelle Memorial institute, nor any of their employees, makes any warranty, expressed or implied, or assumes any legal Inbiltty or responsibility for the accuracy, completeness, or usefulness of any information, apparatus, product, or process disclosed, or represents that its use would not infringe privately owned rights. Reference herein to any specific commercial product, process, or service by trade name, trademark, manufacturer, or otherwise, does not necessarily constitute or imply its endorsement, recommendation, or favoring by the United States Government of any agency thereof, or Battelle Memorial Institute. The views and opinions of authors expressed herein do not necessarily state or reflect those of the United States Government or any agency thereof.

\author{
PACIFIC NORTHWEST LABORATORY \\ operated by \\ BATTELLE MEMORIAL. INSTITUTE \\ for the \\ UNITED STATES DEPARTMENT OF ENERGY \\ under Contract DE-ACO6-76RLO 1830
}

Printed in the United States of America

Available to DOE and DOE contractors from the

Office of Scientific and Technical Information, P.O. Box 62, Oak Ridge, TN 37831; prices available from (615) 576-8401. FTS 626-8401.

Available to the public from the National Technical Information Service, U.S. Department of Commerce, 5285 Porl Royal Rd, Springfield, VA 22161.

NTIS Price Codes, Microfiche A01

Printed Copy

\begin{tabular}{cr}
\hline Prtce Code & Page Range \\
\hline A02 & $1-10$ \\
A03 & $11-50$ \\
A04 & $51-75$ \\
A05 & $76-100$ \\
A06 & $101-125$ \\
A07 & $126-150$ \\
A08 & $151-175$ \\
A09 & $176-200$ \\
A10 & $201-225$ \\
A11 & $226-250$ \\
A12 & $251-275$ \\
A13 & $276-300$ \\
A14 & $301-325$
\end{tabular}

\begin{tabular}{cc}
\hline Price Code & Page Range \\
\hline A15 & $326-350$ \\
A16 & $351-375$ \\
A17 & $376-400$ \\
A18 & $401-425$ \\
A19 & $426-450$ \\
A20 & $451-475$ \\
A21 & $476-500$ \\
A22 & $501-525$ \\
A23 & $526-550$ \\
A24 & $551-575$ \\
A25 & $576-600$ \\
A99 & $601-U p$
\end{tabular}


VISCOSITY, ELECTRICAL CONDUCTIVITY, AND CESIUM VOLATILITY OF ORNL VITRIFIED SOILS WITH LIMESTONE AND SODIUM ADDITIVES
J. W. Shade
G. F. Piepe1

May 1990

Prepared for

the U.S. Department of Energy

under Contract DE-AC06-76RLO 1830

Pacific Northwest Laboratory

Richland, Washington 99352 



\section{SUMMARY}

Engineering- and pilot-scale tests of the in situ vitrification (ISV) process have been conducted for Oak Ridge National Laboratory (ORNL) to successfully demonstrate the feasibility of applying ISV to seepage trenches and pits at ORNL. These sites contain soil that overlies crushed limestone fil1; therefore, the 1SV process is applied to a soil-7imestone mixture. Previous testing indicated that while a good retention level of ${ }^{137} \mathrm{Cs}$ and ${ }^{90} \mathrm{Sr}$ was achieved in the melt, it would be desirable to improve ${ }^{137} \mathrm{Cs}$ retention to $99.99 \%$ if possible to minimize activity in the off-gas system. Previous testing was 1 inited to one soil-limestone composition. Both Cs volatility and $15 \mathrm{~V}$ power requirements are in part dependent on melt temperature and viscosity, which depend on melt composition. The study described in this report determined the effect of varying soil and limestone compositions, as well as the addition of a sodium flux, on melt viscosity, electrical conductivity, and Cs volatility.

The compositional range investigated was 50 to $100 \%$ ORNL soil, 0 to $50 \%$ $\mathrm{CaO}$ in the form of 7 imestone $\left(\mathrm{CaCO}_{3}\right)$, and $\mathrm{O}$ to $15 \% \mathrm{Na}_{2} \mathrm{O}$ in the form of sodium carbonate $\left(\mathrm{Na}_{2} \mathrm{CO}_{3}\right)$. For the viscosity and electrical conductivity measurements, 11 distinct compositions were prepared with 3 replicates for a total of 14 samples. The compositions were generated according to a statistically designed matrix and property measurements were determined at a minimum of three different temperatures. A total of five compositions from this matrix, spiked with $\mathrm{Cs}_{2} \mathrm{CO}_{3}$, were used to obtain $\mathrm{Cs}$ volatility data at constant temperature $\left(1330^{\circ} \mathrm{C}\right)$ and constant viscosity (100 poise). All measurements were made on glasses prepared from these compositions rather than during initial melting.

The temperature required to obtain the 100-poise viscosity (T100P) in a pure soil me1t was $1735^{\circ} \mathrm{C}$; the electrical conductivity at this temperature was $0.028(\mathrm{ohm}-\mathrm{cm})^{-1}$. At the other extreme, a T100P of $1200^{\circ} \mathrm{C}$ was determined for a composition of $50 \%$ soil-35\% $\mathrm{Ca} 0-15 \% \mathrm{Na}_{2} \mathrm{O}$, which had an electrical conductivity of $0.116(0 \mathrm{hm}-\mathrm{cm})^{-1}$. The highest conductivity measured at a T100P of $1233^{\circ} \mathrm{C}$ was $0.263(\mathrm{ohm}-\mathrm{Cm})^{-1}$ for a composition of $\left.67.5 \% 501\right]-17.5 \%$ 
Ca0-15\% $\mathrm{Na}_{2} \mathrm{O}$. Similar trends were also observed for data obtained at a constant temperature of $1330^{\circ} \mathrm{C}$.

At the present time, theoretical models that accurately predict viscosity and electrical conductivity properties have not been evaluated for this ISV application, so nine empirical mixture models were fitted to the Tloop and electrical conductivity data. A quadratic Scheffé model provided the best fit for T100P, electrical conductivity at T100P, as well as viscosity and electrical conductivity at $1330^{\circ} \mathrm{C}, \mathrm{R}^{2}$ values of 0.96 or better were obtained for all four properties. The fitted quadratic mixture models were used to generate contour plots of the properties related to composition, as well as plots of the effects of compositional changes on the properties.

At a constant viscosity of 100 poise, Cs volatility ranged from 0.12 to $0.76 \%$ of the amount $(-2.0 \mathrm{wt} \%)$ present in the initial melt for mixtures with soil concentrations from 50 to $85 \%$. At $1330^{\circ} \mathrm{C}$, Cs volatility was 0.12 to $1.30 \%$ over a range of 25 to 316 poise. Neither the constant temperature nor the constant viscosity measurements were 7 inear with soil concentration. The lowest volatility occurred in the $\mathrm{Na}_{2} \mathrm{O}$-free mixture of $75 \%$ soil-25\% $\mathrm{Ca} 0-0 \% \mathrm{Na}_{2} \mathrm{O}$ and was $0.12 \%$.

This study indicated that increasing the soil fraction in the melt results in a higher viscosity for a given temperature, but does not have a large effect on electrical conductivity. Electrical conductivity is more sensitive to $\mathrm{Na}_{2} \mathrm{O}$ content than soil or $\mathrm{CaO}$. Up to $25 \% \mathrm{CaO}$ content results in a decrease in viscosity at constant temperature, but higher concentrations have less effect. The apparent effect of high-Ca0 concentrations on viscosity may be misleading, however, because crucible-melt reactions during initial melting of high-CaO mixtures resulted in a deviation from target compositions. 


\section{ACKNOWLEDGMENTS}

Pacific Northwest Laboratory (PNL) gratefully acknowledges the Oak Ridge National Laboratory (ORNL) for the opportunity to conduct this study. We especially thank Brian Spalding and Gary Jacobs of the ORNL Environmental Sciences Division for their support and interest. We would also like to thank Steve Bates, Gary Carter, and Craig Timmerman, all of PNL, for their support and encouragement.

Don Smith and Mike Schweiger are thanked for their high-quality Taboratory efforts in sample preparation and measurements of viscosity and electrical conductivity. Also, Frank Hara and his analytical staff are thanked for providing chemical analyses of glass samples. 
- 
CONTENTS

SUMMARY ........................... $i$ i

ACKNOWLEDGMENTS ....................

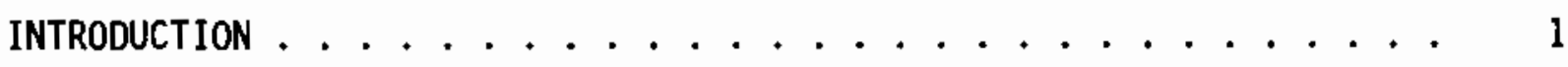

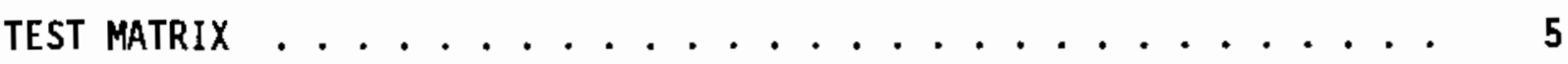

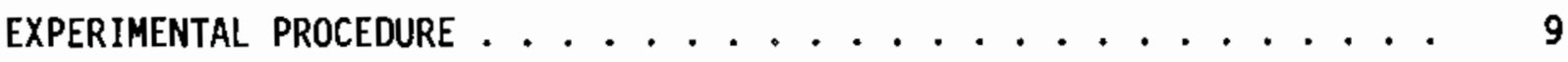

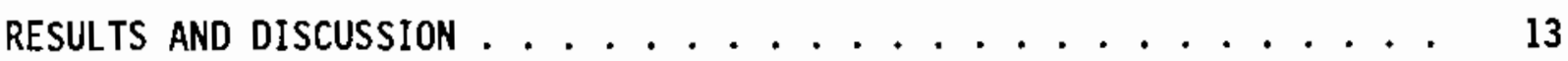

VISCOSITY AND ELECTRICAL CONDUCTIVITY RESULTS . . . . . . . . 13

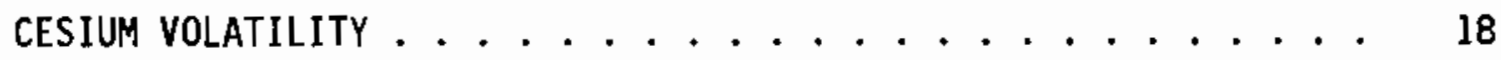

EMPIRICAL MODELING AND STATISTICAL ANALYSES ........... 23

FITTING MIXTURE MODELS TO THE DATA ............ 23

PREDICTIONS AND PREDICTION CONFIDENCE INTERVALS

WITH THE FITTED MODELS ................ 27

CONTOUR AND COMPONENT EFFECTS PLOTS FROM THE

FITTED MIXTURE MODELS . . . . . . . . . . . . . . 29

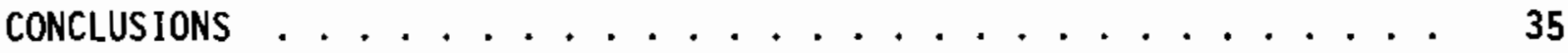

REFERENCES ......................... 37

APPENDIX A - COMPARISON OF TARGET AND ACTUAL MELT COMPOSITIONS . . . A. A

APPENDIX B - VISCOSITY AND ELECTRICAL CONDUCTIVITY

EXPERIMENTAL DATA ................ B.

APPENDIX C - PREDICTION STANDARD DEVIATIONS AND CONFIDENCE

INTERVALS FOR PREDICTIONS FROM QUADRATIC

SCHEFFE MIXTURE MODELS

C.1 


\section{FIGURES}

1 The Soil-CaO- $\mathrm{Na}_{2} \mathrm{O}$ Compositional Region and the 14-Point Test Matrix ............. 6

2 Schematic of Furnace and Off-Gas Collection System ...... 12

3 Tloop versus F/M Ratio ................. 17

4 Viscosity at $1330^{\circ} \mathrm{C}$ Versus $\mathrm{F} / \mathrm{M}$ Ratio ........... 17

5 Sodium Content Versus Electrical Conductivity . . . . . . . . 18

6 Cesium Volatility from Melts at Various

Viscosities and Temperatures ................. 19

7 Contour Plot for TlOOP ................ 30

8 Contour Plot for ECTIOOP .............. 30

9 Contour Plot for $\mathrm{V} 1330 \ldots \ldots$. . . . . . . . . 31

10 Contour Plot for $\mathrm{ECl} 330 \ldots \ldots$. . . . . . . . . . 31

11 Directions Used for $\mathrm{Na}_{2} \mathrm{O}$, Soil, and $\mathrm{CaO}$ Effects

Plots in Figures 12 through $15 \ldots . . . . . . . . .32$

12 Effects of $\mathrm{Na}_{2} \mathrm{O}, \mathrm{CaO}$, and Soil Compositional Changes

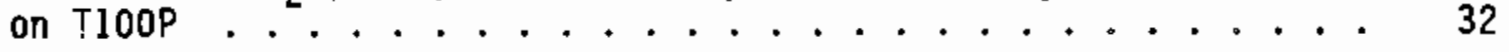

13 Effects of $\mathrm{Na}_{2} \mathrm{O}$, Ca0, and Soil Compositional Changes on Electrical Conductivity at T100P ........... 33

14 Effects of $\mathrm{Na}_{2} \mathrm{O}, \mathrm{CaO}$, and Soil Compositional Changes on Viscosity at $1330^{\circ} \mathrm{C} \ldots \ldots . \ldots 33$

15 Effects of $\mathrm{Na}_{2} \mathrm{O}, \mathrm{CaO}$, and Soil Compositional Changes on Electrical Conductivity at $1330^{\circ} \mathrm{C} \ldots \ldots . . . . . . .34$ 


\section{$\underline{\text { TABLES }}$}

1 Test Matrix and Randomized Run Order for ISV Three-Component Study................ 6

2 ORNL Soil and Limestone Bulk Compositions and Vitrified ORNL Soil Composition.................. 9

3 T100P and Electrical Conductivities of ORNL/ISV Compositions .................... 14

4 Viscosities and Electrical Conductivities at $1330^{\circ} \mathrm{C}$ for ORNL/ISV Compositions ............... 15

$5 \quad$ T100P and Electrical Conductivities in Terms of Actual-Melt Partial Composition ........... 16

6 Cesium Volatility of Selected Samples at Constant Temperature and viscosity.............. 18

7 The Mixture Model Forms Considered ... . . . . . . . 24

8 Transformations Applied to Glass Properties Prior to Fitting Final Quadratic Scheffe Mixture Models ........ 25

9 Coefficients, Coefficient Standard Deviations, $R^{2}$ Values, and Indications of Statiştically Significant Lack-of-Fits for the Quadratic Scheffe Mixture Models Fitted to Transformed Values of T100P, ECTIOOP, V1330, and EC1330 Using the Data from Tables 3 and $4 \ldots \ldots$ 



\section{INTRODUCTION}

Several studies have been conducted to determine the potential for applying the in situ vitrification (ISV) process to seepage pits and trenches contaminated with low- and intermediate-level waste at 0ak Ridge National Laboratory (ORNL). These studies have included a laboratory test on a $50 \%$ ORNL soil-50\% limestone mixture, an engineering-scale test on a 1/12-scale simulated trench, and a pilot-scale test on a $3 / 8$-scale simulated trench (Carter et a). 1987 and 1988). While these tests demonstrated the feasibility of applying the ISV process to ORNL contaminated sites, they were limited to only one soil-limestone mixture. They demonstrated that even though a very good retention of the major radionuclide components, ${ }^{137} \mathrm{Cs}$ and ${ }^{90} \mathrm{Sr}$, was achieved, it would be desirable to improve ${ }^{137} \mathrm{Cs}$ retention to minimize activity in the off-gas system. Cesium retention levels of $99.99 \%$ or more are desired within the melt zone. Cesium volatility is dependent on melt viscosity and temperature, so it is necessary to determine an optimum viscosity and electrical conductivity to minimize Cs volatility while maintaining the best ISV operating conditions.

In the ISV process, the ideal product is a homogeneous glass monolith obtained from melting contaminated soil or other waste. To help mix contaminants, it is necessary to have some convection in the melt. Temperature gradients and lower viscosities improve convection so that an upper practical limit for viscosity in a given application exists. The electrical conductivity of the melt influences the voltage and current of the ISV system that is required to achieve optimum power density. The current supplied by the ISV system is limited, so a high soil conductance may be undesirable. The temperature dependence of both the viscosity and electrical conductivity of a melt approximates Arrhenius behavior as long as excessive crystallization does not occur. Thus, the three factors (viscosity, electrical conductivity, and melt temperature) can be controlled somewhat by adjusting composition and power density.

Fluxes such as $\mathrm{Na}$ that are added to soil-limestone mixtures result in lower viscosities for a given temperature. Spalding (1989) investigated the 
effect of Na additives on the Cs volatility and leachability of a 7:3 soillimestone mixture. The present study contributes to this effort by investigating the viscosity and electrical conductivity of a range of soillimestone-Na mixtures that include those expected in ORNL trenches and pits. The 7:3 mixture investigated by Spalding is al so included within this compositional range. These measurements were done over a range of temperatures. These data were then used to develop an empirical relationship relating composition to viscosity and electrical conductivity allowing interpolation within the region covered by the compositional matrix. In addition, several samples were spiked with $C s$ and then used to determine Cs volatility as a function of viscosity, composition, and temperature. It is expected that the results of the study will help determine optimum ISV operating parameters and also provide a basis for determining if additional Cs retention systems are required. Spalding (1989) has suggested several such systems, including a $C_{s}$ reflux system, in the event that $C_{s}$ volatility cannot be sufficiently controlled by adjusting melt viscosity.

This study focused on ISV applications to ORNL soil-limestone trenches and was not considered to be a generic study of ISV melt compositions and applications. The intent was to determine if fluxing agents should be considered in the ORNL/ISV application, including the design of future engineering-scale tests, and if their use might have an adverse effect on $C s$ volatility through changes in melt viscosity. In the ISV application to ORNL, trench compositions are known or estimated in terms of soil-tolimestone proportions rather than actual oxide compositions. Accordingly, it was desired to have a means of interpolating between measured viscosities and electrical conductivities in terms of these constituents plus the flux, $\mathrm{Na}_{2} \mathrm{CO}_{3}$. Eleven different soil-limestone-sodium carbonate mixtures were selected that included, as well as exceeded, expected trench compositions. Three replicates were also selected for a total of 14 samples. The 14 samples were arranged in a statistically designed matrix that was used to fit an empirical function to the viscosity and electrical conductivity data for interpolation between mixtures. During the initial melting, some of the high CaO content mixtures reacted with the crucibles resulting in a melt with a different composition than would be expected if no reaction had occurred. 
Crucible-melt reactions primarily resulted in 10 wer $\mathrm{Ca} / \mathrm{Si}$ melt ratios than might be expected based on the initial soil-limestone-sodium carbonate mixtures. Since the initial 11 mixture compositions and 3 replicates were used with the measured viscosity and electrical conductivity data to develop the empirical mode1, the model may predict higher viscosities than expected for mixtures with high limestone content in the absence of crucible-melt reactions. For the present ISV applications, however, this deviation may not be significant because operating controls can be adjusted to accommodate it. Data on actual melt compositions were obtained for future use in evaluating the applicability of both empirical and theoretical models of viscosity and electrical conductivity to a broader range of ISV applications than considered in this study. 


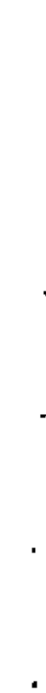




\section{TEST MATRIX}

The seepage trenches at ORNL contain a crushed limestone dispersant covered with soil. Sodium acts as a network modifier for glass to reduce viscosities and is being considered as a possible additive to soil-1imestone mixtures in this ISV application. Thus, a three-component system consisting of ORNL soil, limestone, and $\mathrm{Na}_{2} \mathrm{O}$ mixtures was selected for investigation. For purposes of this investigation, soil, $\mathrm{CaO}$ (from 1 imestone), and $\mathrm{Na}_{2} \mathrm{O}$ (from sodium carbonate) are considered components. Eleven different mixtures of these components were selected based on expected compositions of interest for ORNL/ISV applications. For each component, the compositional ranges considered were 50 to $100 \%$ soil, 0 to $50 \% \mathrm{CaO}$, and 0 to $50 \% \mathrm{Na}_{2} \mathrm{O}$. The compositional region is shown in Figure 1 in terms of the weight percents of the components. Three replicate compositions, indicated by circles in Figure 1, were also selected so that a total of 14 samples were used. Figure 1 depicts the mixture compositions before initial melting.

A test matrix of 14 samples was generated using a statistical mixtureexperiment design approach (Cornell 1981). The matrix consists of the four vertices (corner points), the four edge centroids, and the overall centroid of the compositional region. Also included were two compositions on the interior of the region, and three replicates to provide for lack-of-fit testing of fitted empirical mixture models (Cornell 1981). The 14 samples comprising the test matrix are listed in Table 1 and displayed in Figure 1. The randomized run order shown in Table 1 was assigned to the 14 samples to minimize experimental biases, and because only one viscosity or electrical conductivity measurement could be made at a time. The compositions in Table 1 and Figure 1 are as-batched (before initial melting).

The source of $\mathrm{Ca}$ and $\mathrm{Na}$ used in the mixtures was 1 imestone $\left(\mathrm{CaCO}_{3}\right)$ and sodium carbonate $\left(\mathrm{Na}_{2} \mathrm{CO}_{3}\right)$, respectively. These two components are reported in terms of oxide weight percents ( $w$ t\% $\mathrm{CaO}$ and $\mathrm{Na}_{2} \mathrm{O}$ ) in Table 1 . The required oxide concentrations were calculated by multiplying the stoichiometric oxide fraction by the appropriate amounts of 1 imestone and sodium 


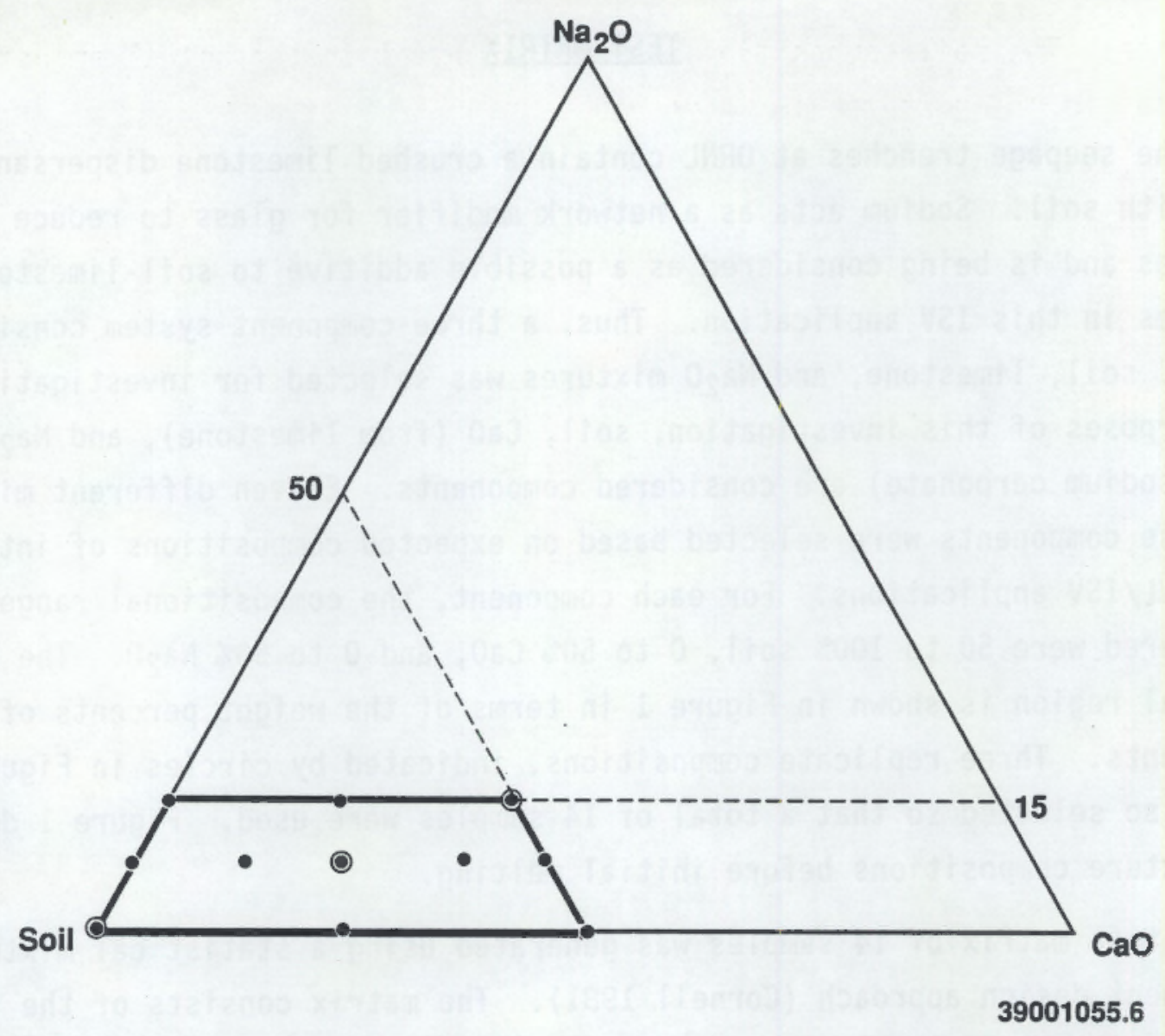

FIGURE 1. The Soil-CaO-Na2 O Compositional Region and the 14-Point Test Matrix (wt\%)

TABLE 1. Test Matrix and Randomized Run Order for ISV Three-Component Study

\begin{tabular}{|c|c|c|c|c|c|}
\hline $\begin{array}{c}\text { Composition } \\
\text { Point } \\
\end{array}$ & Run \# & $\begin{array}{l}\text { Soil } \\
\text { (wt\%) }\end{array}$ & $\begin{array}{l}\text { Limestone } \\
\text { (CaO) (wt\%) }\end{array}$ & $\begin{array}{c}\text { Sodium } \\
\text { Carbonate } \\
\text { (Na20) (wt\%) }\end{array}$ & Type of Point \\
\hline 1 & 1 & 100.0 & 0.0 & 0.0 & vertex \\
\hline 2 & 6 & 85.0 & 0.0 & 15.0 & vertex \\
\hline 3 & 3 & 50.0 & 35.0 & 15.0 & vertex \\
\hline 4 & 12 & 50.0 & 50.0 & 0.0 & vertex \\
\hline 5 & 4 & 92.5 & 0.0 & 7.5 & edge centroid \\
\hline 6 & 13 & 75.0 & 25.0 & 0.0 & edge centroid \\
\hline 7 & 8 & 50.0 & 42.5 & 7.5 & edge centroid \\
\hline 8 & 7 & 67.5 & 17.5 & 15.0 & edge centroid \\
\hline 9 & 14 & 71.25 & 21.25 & 7.5 & overall centroid \\
\hline 10 & 9 & 81.875 & 10.625 & 7.5 & interior check pt \\
\hline 11 & 5 & 60.625 & 31.875 & 7.5 & interior check pt \\
\hline 12 & 10 & 100.00 & 0.0 & 0.0 & replicate of \#1 \\
\hline 13 & 11 & 50.0 & 35.0 & 15.0 & replicate of $\# 3$ \\
\hline 14 & 2 & 71.25 & 21.25 & 7.5 & replicate of $\# 9$ \\
\hline
\end{tabular}


carbonate. The soil composition listed in Table 1 is the actual amount of soil used in the mixtures in weight percent.

In addition to viscosity and electrical conductivity measurements, five of the above compositions were selected for Cs volatility studies. Compositions 2, 3, and 6 in Table 1 were spiked with $-2 \% \mathrm{Cs}_{2} \mathrm{O}$ to determine the amount of $\mathrm{Cs}$ volatilized at a constant viscosity of 100 poise at three different temperatures. Composition 6 in Table 1 yielded a 100-poise viscosity at $1330^{\circ} \mathrm{C}$; it also served as a data point for measurements of Cs volatility at a constant-temperature of $1330^{\circ} \mathrm{C}$ but variable viscosity. The other two compositions for the constant-temperature Cs volatility determinations were points 7 and 2 . The Cs volatility measurements are discussed in more detail in the following section. 



\section{EXPERIMENTAL PROCEDURE}

The soil and limestone used for these experiments were received from ORNL and are expected to be similar to the materials used by Spalding (1989). The soil and limestone were prepared as starting materials using a procedure nearly identical to the procedure used by Spalding. Approximately $3 \mathrm{~kg}$ each of the soil and limestone were crushed to pass a 8-mesh sieve $(-2.4 \mathrm{~mm})$ and were dried for $72 \mathrm{~h}$ at $90^{\circ} \mathrm{C}$. A partial analysis of each of these materials, which are believed to be representative of the bulk soil and limestone, is given in Table 2 along with the analysis of ORNL soil reported by Spalding (1989). Table 2 also includes the composition of a glass prepared by melting ORNL soil at more than $1500^{\circ} \mathrm{C}$ for comparison with the unmelted soil. All compositions must be melted before making viscosity and electrical conductivity measurements; therefore, these two analyses provide an indication of the change in soil composition expected during melting.

Amounts of dried soil, limestone, and $\mathrm{Na}_{2} \mathrm{CO}_{3}$ were weighed and mechanically mixed to achieve the target compositions given in Table 1. Each composition was melted at sufficiently high temperature to obtain a glass made by pouring the melt on a steel plate. This initial melting was done in highsilica crucibles. Soil-rich samples that were relatively high in silica did

TABLE 2. ORNL Soil and Limestone Bulk Compositions and Vitrified ORNL Soil Composition

Oxide Soil (wt\%) Soil Melt (wt\%) Soil (wt\%)(a) Limestone (wt\%)

$\begin{array}{llllc}\mathrm{Al}_{2} \mathrm{O}_{3} & 16.3 & 18.4 & 18.4 & 1.7 \\ \mathrm{SiO}_{2} & 55.6 & 62.6 & 57.3 & 5.3 \\ \mathrm{TiO}_{2} & 0.70 & 0.8 & 0.81 & \\ \mathrm{CaO} & 5.4 & 5.9 & 2.5 & 47.6 \\ \mathrm{SrO} & 0.02 & 0.02 & 0.06 & 0.05 \\ \mathrm{MgO} & 2.0 & 2.0 & 1.8 & 3.6 \\ \mathrm{MnO} & 0.10 & 0.13 & 0.09 & 0.03 \\ \mathrm{Fe}_{2} \mathrm{O}_{3} & 5.6 & 6.21 & 6.2 & 0.7 \\ \mathrm{~K}_{2} \mathrm{O} & 4.1 & 3.6 & 3.8 & 1.5 \\ \mathrm{Na}_{2} \mathrm{O} & 1.3 & 1.2 & 1.0 & 0.5 \\ \mathrm{H}_{2} & & & & \end{array}$

(a) From Spalding (1989). 
not react significantly with the crucibles, but samples with more than $-25 \%$ $\mathrm{CaO}$ tended to result in less $\mathrm{Ca}$ and considerably more $\mathrm{Si}$ in the melt than specified in the target composition. These high-Ca compositions generally yielded a melt with a $\mathrm{SiO}_{2} / \mathrm{CaO}$ mole ratio of about 2, which suggests that some sort of phase boundary was approached. Examination of the $\mathrm{CaO}-\mathrm{Al}_{2} \mathrm{O}_{3}$ $\mathrm{SiO}_{2}$ system indicates a ternary eutectic involving pseudowollastonite (CaO $\left.\mathrm{SiO}_{2}\right)$, anorthite $\left(\mathrm{CaO} \cdot \mathrm{Al}_{2} \mathrm{O}_{3} \cdot 2 \mathrm{SiO}_{2}\right)$, and silica $\left(\mathrm{SiO}_{2}\right)$, with a melt composition near a $2: 1$ mole ratio of $\mathrm{SiO}_{2} / \mathrm{CaO}$. This melt composition is similar to that observed in some of the initial melts with high $\mathrm{Ca}$ concentrations. The similarity between the $\mathrm{SiO}_{2} / \mathrm{CaO}$ ratios observed in the initial melt and that expected from the $\mathrm{CaO}-\mathrm{Al}_{2} \mathrm{O}_{3}-\mathrm{SiO}_{2}$ system suggests that melt-crucible reactions resulting in the formation of pseudowollastonite, anorthite, and $\mathrm{SiO}_{2}$ may be partially controlling the high-CaO melt compositions.

The resulting tendency toward similar $\mathrm{SiO}_{2} / \mathrm{CaO}$ ratios in the melts for high Ca0 compositions would tend to produce a greater similarity of viscosities for these melts at a given temperature than might otherwise occur. Other things being equal, $\mathrm{SiO}_{2} / \mathrm{CaO}$ ratios higher than anticipated based on the initial mixture of unmelted components would tend to yield higher viscosities than expected. A number of other factors in addition to composition, however, can influence viscosity, including dissolved gasses and partial crystallization. In addition to melt-crucible reactions, some foaming was observed in several of the high $\mathrm{CaO}$ compositions during the initial melting. The effects of these reactions were not investigated further and are beyond the scope of this study. The major effect is most likely to be on viscosity, however, because electrical conductivity is more dependent on $\mathrm{Na}$ concentration, which did not change as much. Even if melt viscosities for high $\mathrm{CaO}$ compositions are lower than measured, they are probably within the range of control by ISV operating procedures, so the practical effects of melt-crucible reactions are not considered to be a problem. Moreover, similar Ca-Si reactions may occur during ISV application with high limestoneto-soil proportions.

The compositions used for $\mathrm{Cs}_{\mathrm{S}}$ volatility studies were spiked with $\mathrm{Cs}_{2} \mathrm{CO}_{3}$ to achieve about $2 \% \mathrm{Cs}_{2} \mathrm{O}$ concentration. It was found experimentally that a factor of 0.6515 times the appropriate amount of $\mathrm{Cs}_{2} \mathrm{CO}_{3}$, rather than the 
stoichiometric ratio of the oxide to the carbonate, was required to achieve $2 \% \mathrm{Cs}_{2} \mathrm{O}$ compositions because some of the $\mathrm{Cs}$ was lost to volatilization during the initial melting of the soil-limestone-sodium carbonate mixtures.

Viscosity measurements were made using a Brookfield rotating spindle viscometer, model LVTD, with a Pt spindle suspended in the melt at a predetermined depth. Approximately $150 \mathrm{~g}$ of $\mathrm{glass}$ in a $\mathrm{Pt}$ crucible were required for each measurement. Furnace temperatures were measured using Pt-10\% Rh thermocouples. The viscometer was calibrated with National Bureau of Standards (NBS) $711 \mathrm{glass.} \mathrm{Viscosities} \mathrm{were} \mathrm{measured} \mathrm{at} \mathrm{a} \mathrm{minimum} \mathrm{of} \mathrm{three}$ temperatures.

Electrical conductivities of the glasses were measured with a two-probe method immediately after the viscosity measurements using the same melt. The conductivity probes, made of Pt-Pt10\%Rh and separated by a known distance, were placed in the melt at a predetermined depth. Resistance measurements were made using ac at $1000-\mathrm{Hz}$ to avoid polarization effects. The electrical conductivity system was also calibrated using NBS 711 glass and measurements on the soil-melt glasses were made at a minimum of three temperatures.

Determinations of Cs volatility from analyzed Cs-spiked glasses were made by placing $100 \mathrm{~g}$ of glass in a Pt crucible, which was placed in a closed-end alumina tube. The tube, $75 \mathrm{~cm}$ long, was placed vertically in a resistance furnace so that the sample was in the maximum heat zone with part of the tube extending above the top of the furnace. A fitting on the open end of the tube above the furnace provided for Ar flowing into the tube, with an exit into three erlenmyer flasks filled with known amounts of water, which acted as scrubbers (Figure 2). In a typical run, the glass was held at temperature for $12 \mathrm{~h}$ with Ar flowing so that 3 to 6 bubbles/s were observed in the scrubbers. At the end of a run, $200 \mathrm{~mL}$ of water slightly acidified with about $1-\mathrm{mL}$ pure nitric acid was used to wash the alumina tube after removal of the crucible. This wash solution, as well as the scrubber solutions, which were also acidified, were then analyzed for Cs to determine the amount volatilized from the glass. 


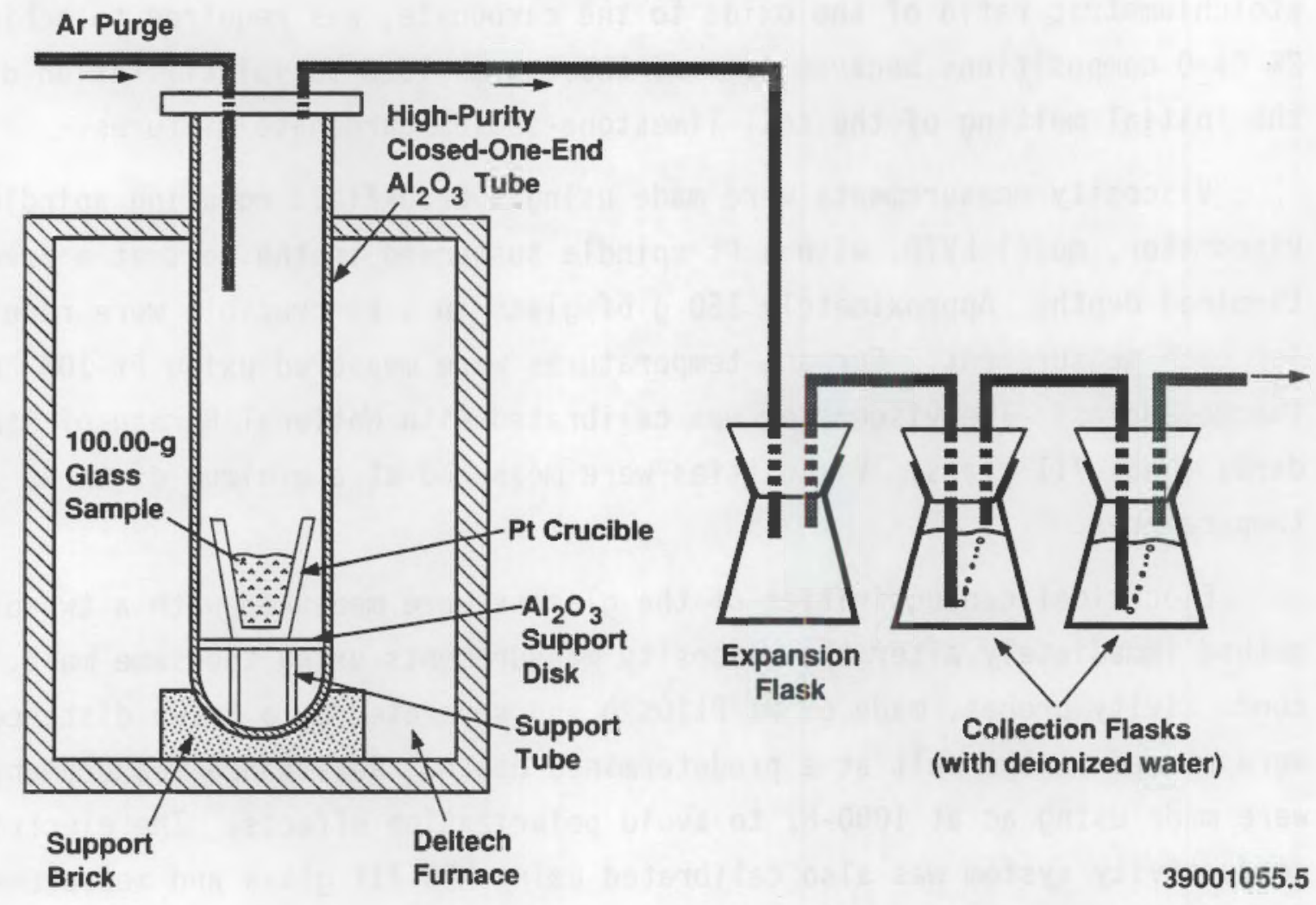

FIGURE 2. Schematic of Furnace and Off-Gas Collection System 


\section{RESULTS AND DISCUSSION}

This section discusses the results of the viscosity and electrical conductivity measurements on the 14 ISV glass compositions and separately presents the results of the Cs volatility determinations as a function of viscosity and temperature.

\section{VISCOSITY AND ELECTRICAL CONDUCTIVITY RESULTS}

A minimum of three measurements were determined for both viscosity and electrical conductivity for each of the 14 samples; the results are given in Appendix B. Appendix B consists of Arrhenius-type plots of the $\log$ of either viscosity or electrical conductivity versus the reciprocal of the absolute temperature for each composition.

For a given composition, the viscosity decreases with increasing temperature and often approximates an Arrhenius relation, as is expected for many glass-forming compositions. The best approximation to Arrhenius behavior occurs with glasses consisting of $70 \%$ or more soil and low Ca0. High-CaO compositions exhibit deviations from Arrhenius behavior, indicated by curvature of the log viscosity versus reciprocal temperature plot. This may occur because $\mathrm{CaO}$ is less effective as a network modifier than $\mathrm{Na}_{2} \mathrm{O}$ in these aluminosilicate systems and can promote early crystallization. One composition, the 50-50 soil-to-Ca0 mixture, was so unstable that a steady viscosity measurement at constant temperature could not be obtained, and the viscosity was estimated by oscillating the furnace temperature and determining a temperature where the viscosity exhibited the least drift.

Electrical conductivity increases with temperature and also approximates Arrhenius behavior. The greatest deviation from this behavior also occurs with high-CaO glass compositions. Electrical conductivity is due in large part to the mobility of alkali ions such as $\mathrm{Na}$ in the glass; therefore, glasses high in $\mathrm{Na}$ exhibit the highest electrical conductivity and also yield the best approximation to an Arrhenius relationship. Thus, maximum power density for ISV applications may be 1 imited by $\mathrm{Na}_{2} \mathrm{O}$ concentration and melt temperature. 
The temperature of the 100-poise viscosity, T100P, was determined by interpolating between measurements of each composition listed in Appendix B with the exception of the high soil compositions. For soil compositions above $90 \%$, it was not possible to make viscosity measurements at temperatures low enough to include the 100-poise point; therefore, the higher-temperature viscosity data were extrapolated to estimate the 100-poise temperature. This approximation involved only composition points 1,5 , and 12 of Table 1.

Electrical conductivity at the 100-poise temperature for each composition was determined in the same manner and also required extrapolation for compositions with greater than $90 \%$ soil. The T100P temperatures and electrical conductivity at that temperature for each of the 14 compositions are given in Table 3. An approximate midrange temperature for 100-poise viscosities was $1330^{\circ} \mathrm{C}$; therefore, the viscosities and electrical conductivities at $1330^{\circ} \mathrm{C}$; are given in Table 4. The data in both Tables 3 and 4 are arranged in order of decreasing soil concentration.

TABLE 3. T100P and Electrical Conductivities of ORNL/ISV Compositions

\begin{tabular}{|c|c|c|c|c|c|}
\hline $\begin{array}{l}\text { Data } \\
\text { Point } \\
\end{array}$ & Soil (wt\%) & $\underline{\mathrm{CaO}}$ (wt\%) & $\mathrm{Na} 20$ (wt $\%)$ & T100P $\left({ }^{\circ} \mathrm{C}\right)$ & $\begin{array}{l}\text { Electrical } \\
\text { Conductivity } \\
\text { at T100p } \\
\text { (ohm-cm) } \\
\end{array}$ \\
\hline $\begin{array}{r}1 \\
12 \\
5 \\
2 \\
10 \\
6 \\
14 \\
9 \\
8 \\
11 \\
7 \\
3 \\
13 \\
4\end{array}$ & $\begin{array}{l}100 \\
100 \\
92.5 \\
85.0 \\
81.875 \\
75.0 \\
71.25 \\
71.25 \\
67.5 \\
60.625 \\
50.0 \\
50.0 \\
50.0 \\
50.0\end{array}$ & $\begin{array}{l}0 \\
0 \\
0 \\
0 \\
10.625 \\
25.0 \\
21.25 \\
21.25 \\
17.5 \\
31.875 \\
42.5 \\
35.0 \\
35.0 \\
50.0\end{array}$ & $\begin{array}{l}0 \\
0 \\
7.5 \\
15.0 \\
7.5 \\
0 \\
7.5 \\
7.5 \\
15.0 \\
7.5 \\
7.5 \\
15.0 \\
15.0 \\
0\end{array}$ & $\begin{array}{ll}1735 \text { (a) } & 0 \\
1751 \text { (a) } & 0 \\
1697(a) & 7.5 \\
1463 & 15 \\
1426 & 18.1 \\
1335 & 25 \\
1270 & 28.75 \\
1292 & 28.75 \\
1233 & 32.5 \\
1286 & 39.5 \\
1238 & 50 \\
1206 & 50 \\
1202 & 50 \\
1327 \text { (b) } 50\end{array}$ & $\begin{array}{l}0.028(a) \\
0.031(a) \\
0.233(a) \\
0.445 \\
0.135 \\
0.024 \\
0.077 \\
0.088 \\
0.263 \\
0.058 \\
0.058 \\
0.105 \\
0.116 \\
0.048\end{array}$ \\
\hline
\end{tabular}

(a) Data obtained by extrapolation.

(b) Unstable melt--see text. 
TABLE 4. Viscosities and Electrical Conductivities at $1330^{\circ} \mathrm{C}$ for ORNL/ISV Compositions

\begin{tabular}{|c|c|c|c|c|c|}
\hline $\begin{array}{l}\text { Data } \\
\text { Point } \\
\end{array}$ & Soil (wt\%) & $\mathrm{CaO}$ (wt\%) & $\mathrm{Na} 20$ (wt\%) & $\begin{array}{c}\text { Viscosity } \\
\text { (poise) } \\
\end{array}$ & $\begin{array}{c}\text { Electrical } \\
\text { Conductivity } \\
\text { (ohm-cm) } \\
\end{array}$ \\
\hline $\begin{array}{r}1 \\
12 \\
5 \\
2 \\
10 \\
6 \\
14 \\
9 \\
8 \\
11 \\
7 \\
3 \\
13 \\
4\end{array}$ & $\begin{array}{l}100 \\
100 \\
92.5 \\
85.00 \\
81.875 \\
75.0 \\
71.25 \\
71.25 \\
67.5 \\
60.625 \\
50.0 \\
50.0 \\
50.0 \\
50.0\end{array}$ & $\begin{array}{l}0 \\
0 \\
0 \\
0 \\
10.625 \\
25.0 \\
21.25 \\
21.25 \\
17.5 \\
31.875 \\
42.5 \\
35.0 \\
35.0 \\
50.0\end{array}$ & $\begin{array}{l}0 \\
0 \\
7.5 \\
15.0 \\
7.5 \\
0 \\
7.5 \\
7.5 \\
15.0 \\
7.5 \\
7.5 \\
15.0 \\
15.0 \\
0\end{array}$ & $\begin{array}{c}7943(a) \\
7943(a) \\
6309(a) \\
316 \\
240 \\
107 \\
52 \\
72 \\
43 \\
52 \\
25 \\
32 \\
30 \\
100(b)\end{array}$ & $\begin{array}{l}0.0048 \text { (a) } \\
0.005(a) \\
0.106 \text { (a) } \\
0.330 \\
0.092 \\
0.024 \\
0.112 \\
0.108 \\
0.322 \\
0.080 \\
0.117 \\
0.240 \\
0.230 \\
0.050\end{array}$ \\
\hline
\end{tabular}

(a) Data obtained by extrapolation.

(b) Unstable melt--see text.

Viscosity and electrical conductivity are functions of the ratio of glass formers, such as $\mathrm{SiO}_{2}$ and certain aluminate groups, to glass modifiers, such as $\mathrm{CaO}$ and $\mathrm{Na}_{2} \mathrm{O}$. Alumina, $\mathrm{Al}_{2} \mathrm{O}_{3}$, behaves as a glass former if the mole fraction of alkali and alkaline earth oxides in the system equals or exceeds the alumina mole fraction. This was the case for all compositions investigated here, so $\mathrm{Al}_{2} \mathrm{O}_{3}$ is considered a glass former in the ORNL melts. Generally, higher viscosities and lower electrical conductivities are associated with higher former (F) to modifier (M) ratios, particularly because of the greater number of bridging oxygens in the higher $F / M$ structure. In order to estimate how some of the more influential oxides might influence melt properties, the 100-poise temperature and the electrical conductivity at those temperatures are given in Table 5 with actual melt compositions of $\mathrm{SiO}_{2}$, $\mathrm{Al}_{2} \mathrm{O}_{3}, \mathrm{CaO}$, and $\mathrm{Na}_{2} \mathrm{O}$. A more theoretical study that would include these plus other oxides as well as soluble gasses and partial crystallization is beyond the scope of this report. It was desired, however, to obtain a preliminary estimate of the possible influence of the four major oxides on melt properties. 
TABLE 5. T100P and Electrical Conductivities in Terms of Actual-Melt Partial Composition

\begin{tabular}{|c|c|c|c|c|c|c|}
\hline $\begin{array}{l}\text { Data } \\
\text { Point } \\
\end{array}$ & $\begin{array}{l}\mathrm{A}_{2}{ }_{2} \mathrm{O}_{3} \\
\text { (wt\%) } \\
\end{array}$ & $\begin{array}{l}\mathrm{SiO}_{2} \\
(\mathrm{wt} \%)\end{array}$ & $\begin{array}{l}\mathrm{CaO} \\
\text { (wt\%) }\end{array}$ & $\begin{array}{l}\mathrm{Na}_{2} \mathrm{O} \\
(\mathrm{wt} \%)\end{array}$ & $\underline{\mathrm{T} 100 \mathrm{P}\left({ }^{\circ} \mathrm{C}\right)}$ & $\begin{array}{c}\text { at T100P } \\
(\mathrm{ohm}-\mathrm{cm})^{-1} \\
\end{array}$ \\
\hline 1 & 18.4 & 62.6 & 5.9 & 1.2 & 1735 & 0.028 \\
\hline 2 & 15.5 & 54.0 & 4.1 & 15.4 & 1463 & 0.445 \\
\hline 3 & 9.4 & 48.2 & 24.7 & 11.0 & 1206 & 0.105 \\
\hline 4 & 9.3 & 47.1 & 34.2 & 0.7 & 1327 & 0.048 \\
\hline 5 & 17.8 & 59.4 & 2.4 & 8.4 & 1697 & 0.233 \\
\hline 6 & 13.6 & 49.1 & 25.6 & 1.0 & 1335 & 0.024 \\
\hline 7 & 9.6 & 45.8 & 30.0 & 6.1 & 1238 & 0.058 \\
\hline 8 & 12.4 & 46.9 & 17.2 & 14.1 & 1233 & 0.263 \\
\hline 9 & 12.9 & 48.4 & 21.2 & 7.5 & 1292 & 0.088 \\
\hline 10 & 15.4 & 52.4 & 13.5 & 8.3 & 1426 & 0.135 \\
\hline 11 & 10.8 & 49.8 & 24.1 & 6.3 & 1286 & 0.058 \\
\hline 12 & 18.6 & 63.0 & 4.5 & 1.3 & 1751 & 0.031 \\
\hline 13 & 9.6 & 47.4 & 24.7 & 11.0 & 1202 & 0.116 \\
\hline 14 & 13.0 & 46.8 & 21.2 & 7.9 & 1270 & 0.077 \\
\hline
\end{tabular}

The T100P data from Table 5 and the viscosity at $1330^{\circ} \mathrm{C}$ data from Table 4 at appropriate $F / M$ ratios were plotted in Figures 3 and 4 to examine the effect of $F / M$ ratio on viscosity. The ratio of the weight percent of $\mathrm{SiO}_{2}$ plus $\mathrm{Al}_{2} \mathrm{O}_{3}$ to the sum of $\mathrm{CaO}$ and $\mathrm{Na}_{2} \mathrm{O}$ from Table 5 are plotted against 100-poise temperatures in Figure 3 and the viscosity of each composition at $1330^{\circ} \mathrm{C}$ in Figure 4. Another way to plot these data would be in terms of the mole fraction of $\mathrm{SiO}_{2}, \mathrm{NaAlO}_{2}, \mathrm{CaAl}_{2} \mathrm{O}_{4}$ (F) to $\mathrm{CaO}$ and $\mathrm{Na}_{2} \mathrm{O}$ (M). For the present purposes, plots of oxide weight percents indicate the desired trends. Figures 3 and 4 indicate that viscosity increases with $F / M$ ratio, as expected. The electrical conductivity versus the amount of $\mathrm{Na}_{2} \mathrm{O}$ in the glass is plotted in Figure 5 and shows that conductivity increases with $\mathrm{Na}_{2} \mathrm{O}$. The increase in electrical conductivity with $\mathrm{NaO}$ content (Figure 5) is approximately linear, but an exponential fit resulted in an $\mathrm{R}^{2}$ similar to a linear fit and is theoretically more appropriate, assuming that $\mathrm{Na}$ diffusion is responsible for electrical conductivity. These figures are intended to provide an indication of some of the compositional effects on melt properties. 

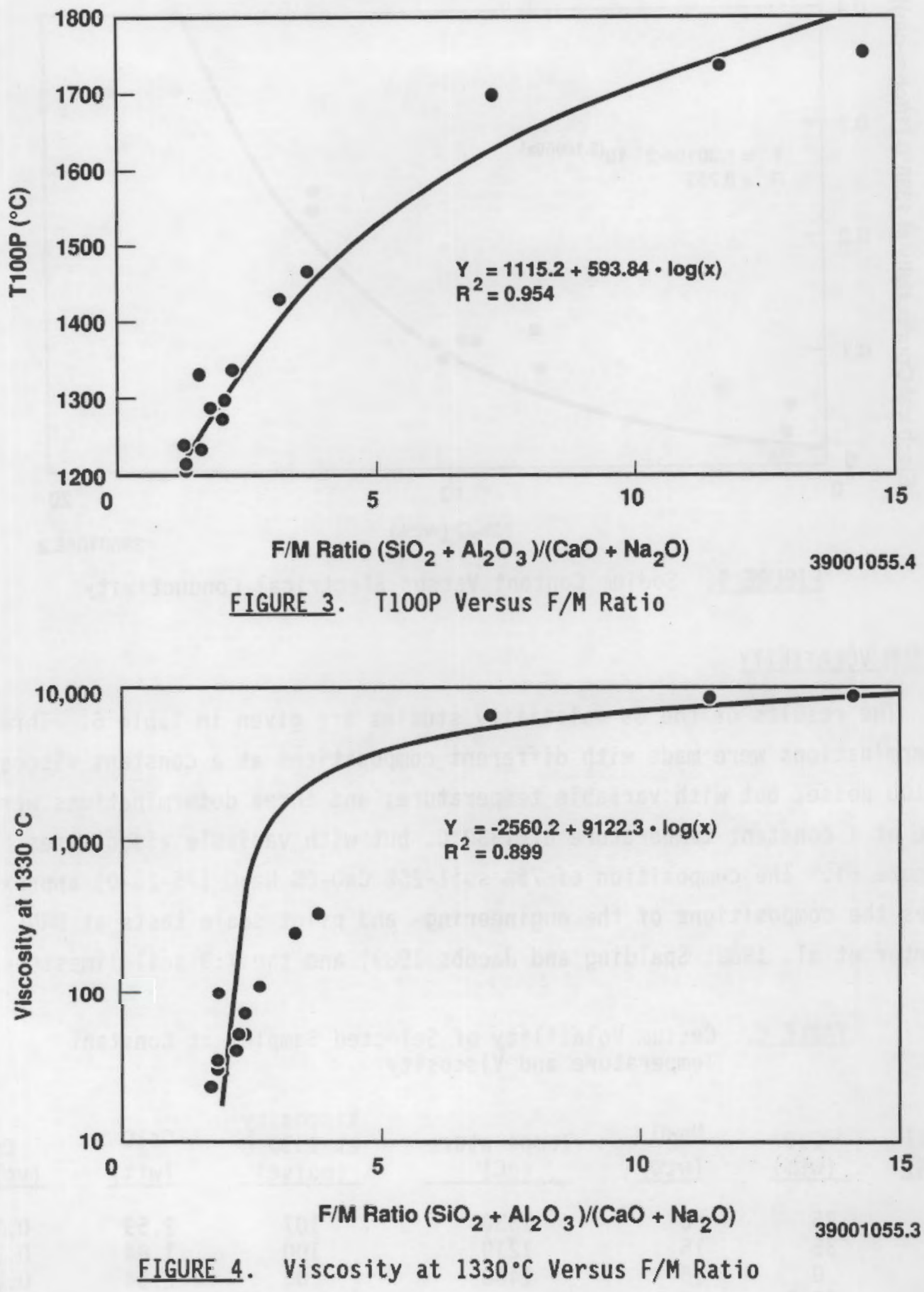


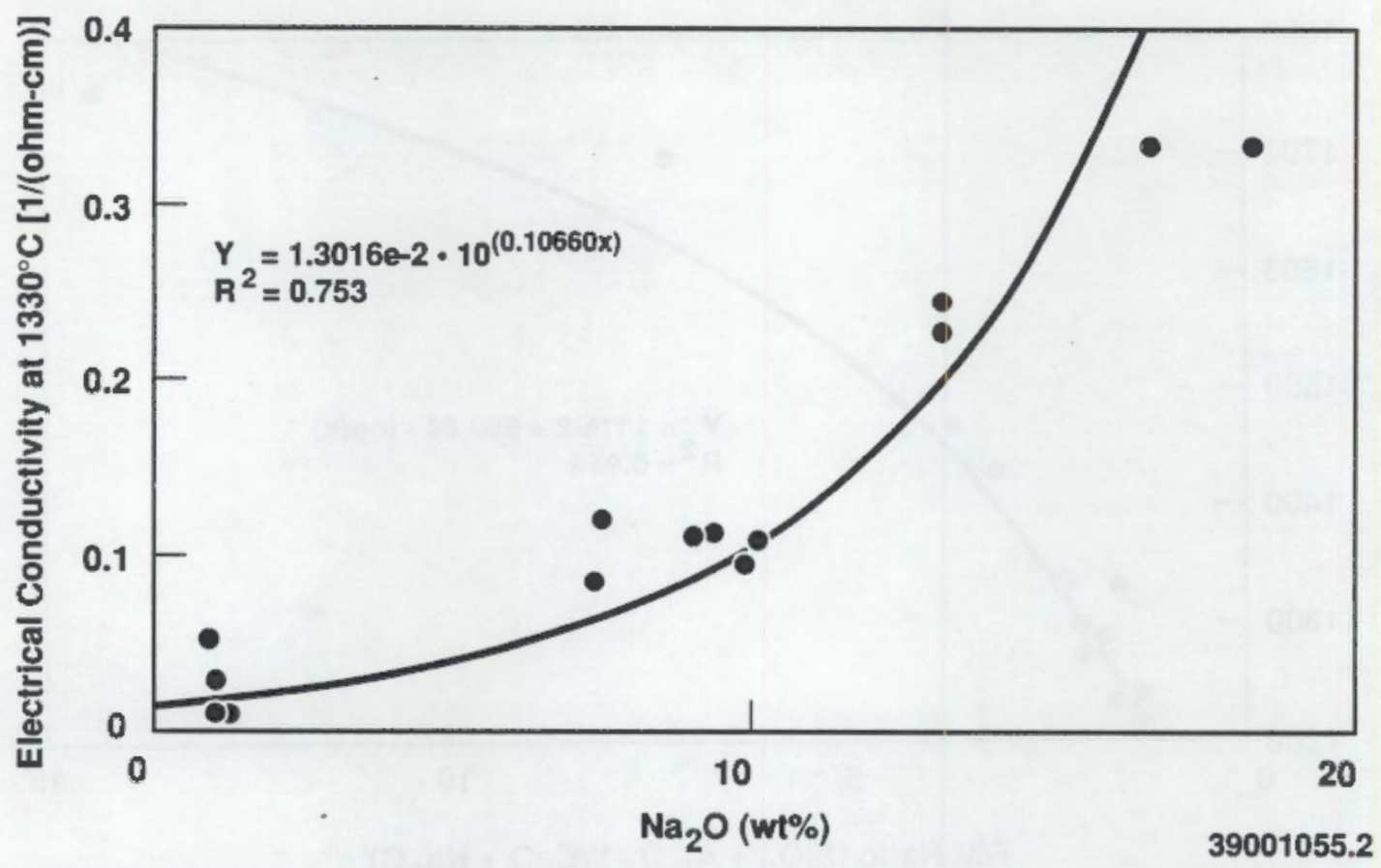

FIGURE 5. Sodium Content Versus Electrical Conductivity

\section{CESIUM VOLATILITY}

The results of the Cs volatility studies are given in Table 6 . Three determinations were made with different compositions at a constant viscosity of 100 poise, but with variable temperature; and three determinations were made at a constant temperature of $1330^{\circ} \mathrm{C}$, but with variable viscosities (Figure 6). The composition of $75 \%$ soil-25\% $\mathrm{Ca} 0-0 \% \mathrm{Na}_{2} \mathrm{O}$ (75-25-0) approximates the compositions of the engineering- and pilot-scale tests at ORNL (Carter et al. 1988; Spalding and Jacobs 1989) and the 7:3 soil-1imestone

TABLE 6. Cesium Volatility of Selected Samples at Constant Temperature and Viscosity

\begin{tabular}{|c|c|c|c|c|c|c|}
\hline $\begin{array}{r}\text { Soil } \\
(w t \%) \\
\end{array}$ & $\begin{array}{c}\mathrm{CaO} \\
(\mathrm{wt} \%) \\
\end{array}$ & $\begin{array}{l}\mathrm{Na}_{2} \mathrm{O} \\
(\mathrm{wt} \%) \\
\end{array}$ & $\begin{array}{l}\text { Temperature } \\
\left({ }^{\circ} \mathrm{C}\right)\end{array}$ & $\begin{array}{l}\text { Viscosity } \\
\text { at } 1330^{\circ} \mathrm{C} \\
\text { (poise) } \\
\end{array}$ & $\begin{array}{l}\mathrm{Cs}_{2} \mathrm{O} \\
(\mathrm{wt} \%) \\
\end{array}$ & $\begin{array}{c}\text { Cs } \\
\text { (vol\%) }\end{array}$ \\
\hline $\begin{array}{l}75 \\
50 \\
85 \\
50 \\
85\end{array}$ & $\begin{array}{c}25 \\
35 \\
0 \\
42.5 \\
0\end{array}$ & $\begin{array}{c}0 \\
15 \\
15 \\
7.5 \\
15\end{array}$ & $\begin{array}{l}1330 \\
1219 \\
1460 \\
1330 \\
1330\end{array}$ & $\begin{array}{r}107 \\
100 \\
100 \\
25 \\
316\end{array}$ & $\begin{array}{l}2.59 \\
1.84 \\
2.54 \\
1.70 \\
2.60\end{array}$ & $\begin{array}{l}0.12 \\
0.51 \\
0.76 \\
1.30 \\
0.55\end{array}$ \\
\hline
\end{tabular}




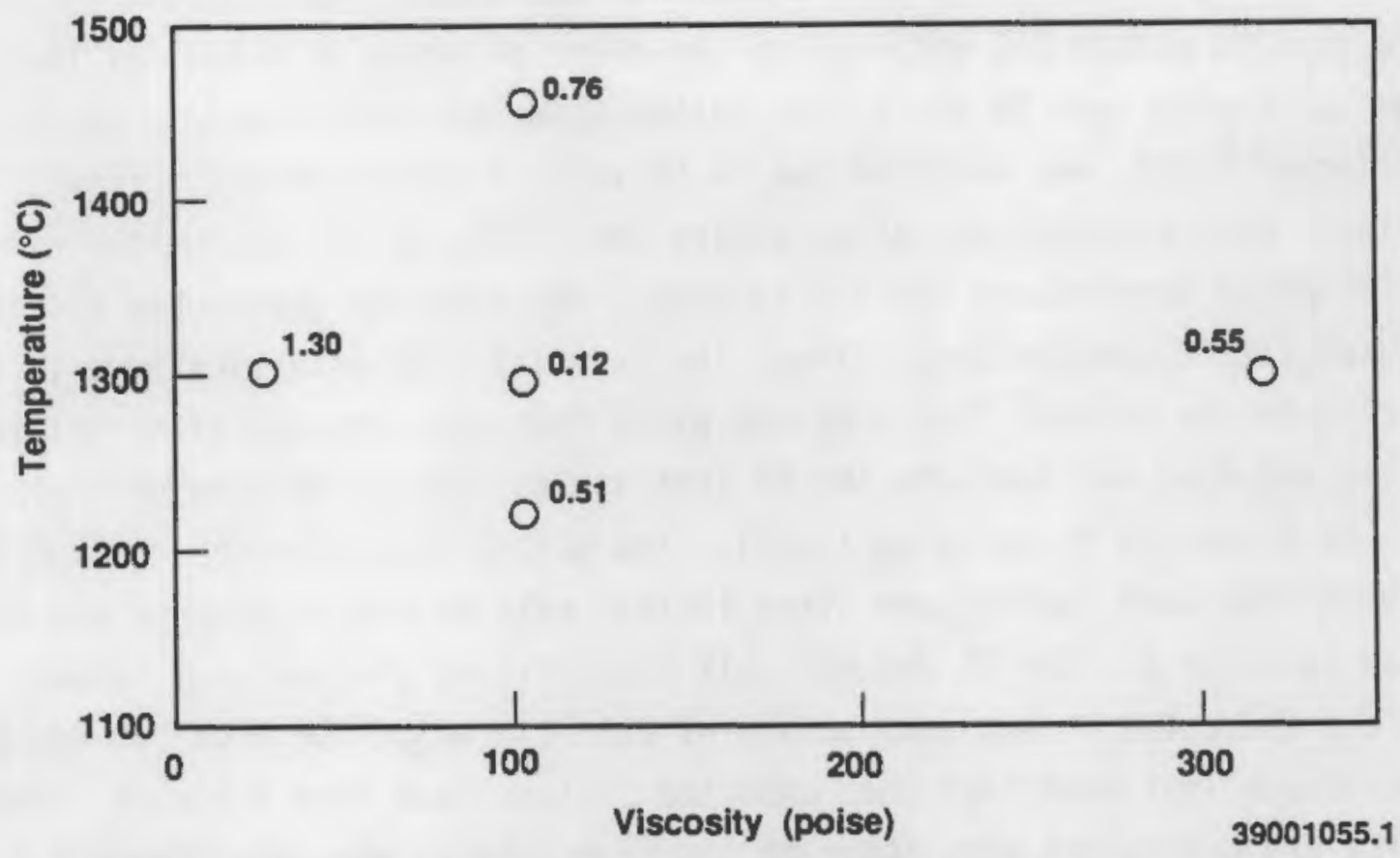

FIGURE 6. Cesium Volatility (wt\%) from Melts at Various Viscosities and Temperatures

mixture of Spalding (1989). (See composition 6 in Table A-1 of Appendix A.) The 75-25-0 composition has a 107-poise viscosity at $1330^{\circ} \mathrm{C}$, which is similar to a 100 -poise temperature of $1325^{\circ} \mathrm{C}$ for the $7: 3$ mixture. Al though the precision of the viscosity measurements was not determined, the measured 107-poise viscosity of the 75-25-0 mixture is considered the same as a 100-poise viscosity because the difference is well within the differences observed for replicates in Tables 3 and 4. The 75-25-0 composition served as a central point in the Cs volatility determinations. The composition of $85 \%$ soil-0\% $\mathrm{Ca} 0-15 \% \mathrm{Na}_{2} \mathrm{O}(85-0-15)$ was used twice but at two different temperatures. It served as the high-temperature point of the constant viscosity runs $\left(1460^{\circ} \mathrm{C}\right)$ and the high-viscosity end of the constant temperature runs $\left(316\right.$-poise at $\left.1330^{\circ} \mathrm{C}\right)$. Two different batches of the 85-0-15 mixture were prepared and spiked for these two determinations, rather than using one large batch because of limited crucible capacity.

As discussed previousiy, to prepare the Cs-spiked compositions, the components for each composition in Table 6 were weighed and an amount of $\mathrm{Cs}_{2} \mathrm{CO}_{3}$ was added so that after melting the $\mathrm{Cs}_{2} \mathrm{O}$ concentration in each 
composition was expected to be $2.0 \mathrm{wt} \%$. It was found from previous experiments that to obtain $2.0 \mathrm{wt} \% \mathrm{Cs}_{2} \mathrm{O}$ in the melt, a factor of 0.6515 of the amount of $\mathrm{Cs}_{2} \mathrm{CO}_{3}$ used in the spike, rather than the stoichiometric oxide fraction of 0.865 , was required due to $C s$ volatilization during initial melting. Each composition, after adding the $\mathrm{Cs}_{2} \mathrm{CO}_{3}$ spike, was melted near its 100-poise temperature for $1 \mathrm{~h}$ to obtain the starting $\mathrm{glass}$ used for the Cs volatility determinations. Thus, the Cs volatility determinations in this report refer to Cs lost from a spiked glass that was reheated after initial melting and does not indicate the Cs lost during initial melting of a mixture, as discussed by Spalding (1989). The actual concentration of $\mathrm{Cs}_{2} \mathrm{O}$ in the glass for each composition after initial melting was determined and is listed in Table 6 . The 75 and $85 \%$ soil compositions yielded $\mathrm{Cs}_{2} \mathrm{O}$ values slightly above the target composition of $2.0 \mathrm{wt} \%$, while the high $\mathrm{CaO}$ and $\mathrm{Na}_{2} \mathrm{O}$ compositions lost more $\mathrm{Cs}_{2} \mathrm{O}$ than expected (values less than $2.0 \mathrm{wt} \%$ ). These results are consistent with those of Spalding (1989), who also observed a greater Cs loss with higher $\mathrm{Na}$ content.

The amount of volatile Cs given in the last column of Table 6 is the sum of the Cs trapped in the scrubbers plus that washed from the alumina tube. More than $90 \%$ of the volatile Cs remained on the walls of the alumina tube. The lowest Cs volatility occurred in the 75-25-0 composition and corresponded to $99.88 \%$ retention at 100 poise and $1330^{\circ} \mathrm{C}$. This composition was the only one considered without additional $\mathrm{Na}$ added. The $99.88 \%$ retention agrees with the results for a pilot-scale test on a similar composition (Carter et al. 1988). At a constant 100-poise viscosity, the higher temperature compositions (usually the most soil-rich) yield a slightly higher Cs volatility than lower temperature compositions. 8ased on only three data points, the temperature effect on Cs volatility was not a linear function of soil concentration as might be expected. Between about $1200^{\circ} \mathrm{C}$ and $1400^{\circ} \mathrm{C}$, the Cs volatility difference between the highest and lowest values was only $0.64 \%$, which suggests that the temperature effect on Cs vapor pressure at a constant melt viscosity is smal1. At a constant temperature of $1330^{\circ} \mathrm{C}$ a 1 arger effect of viscosity on CS volatility is realized compared to the temperature effect, with a difference of $1.18 \%$ Cs loss observed between viscosities of 25 and 316 poise. This suggests that the effect of viscosity on Cs diffusion 
through a melt may be more influential than the vapor pressure effect. The relative effects of $\mathrm{CaO}$ and $\mathrm{Na}_{2} \mathrm{O}$ on Cs volatility are not clear, but based on the data of Table 6 at constant viscosity, Na additives have a greater influence than $\mathrm{Ca}$. At constant temperature, a comparison of the 75-25-0 composition with the 85-0-15 composition suggests that Na may also result in greater Cs volatility than $\mathrm{Ca}$. This is consistent with the results of Spalding (1989) that indicated greater Cs volatility with increased Na concentrations. 



\section{EMPIRICAL MODELING AND STATISTICAL ANALYSES}

Theoretical models that relate glass properties to composition have not been evaluated for this application. Thus, various empirical mixture model forms were considered, as displayed in Table 7. The $x_{j}$ in the model forms denotes the weight fractions(a) of the three components (soi1, $\mathrm{Na}_{2} \mathrm{O}, \mathrm{CaO}$ ) in any given mixture. The $b_{i}, b_{i j}$, etc. represent coefficients to be determined by fitting the model to the data via least squares regression techniques. The model forms displayed in Table 7 have been shown in the statistics literature to provide for fitting a wide range of property behaviors as a function of mixture composition for many different applications.

\section{FITTING MIXTURE MODELS TO THE DATA}

Each of the model forms shown in Table 7 was fitted to each of the four properties for which data are given in Tables 3 and 4 . For discussion purposes, the four properties are abbreviated as T100P, ECT100P, V1330, and ECI330. (b) Initially, the mixture models were fitted to the property data and to logarithmic transformations of the property data in order to determine which model form provided the best fit and to ascertain whether transforming the data affected the goodness of fit. The quadratic Scheffe model seemed to provide the best fit for a11 four properties. Also, these initial results confirmed the expectation that the goodness of fit depends on the property transformation used.

In order to select the best transformation for fitting the Scheffe quadratic mixture model form, the graphical Box-Cox technique discussed by Box and Draper (1987, pp. 289-291) was used. This technique considers the

(a) Mixture models are traditionally written with $x_{j}$ denoting the proportion, rather than percentage, of the ith component in the mixture, hence, the $x_{i}$ sum to 1.0 rather than $100 \%$. The weight percent data in Tables 3 and 4 were re-expressed as weight fractions between 0.0 and 1.0 before fitting the various mixture models shown in Table 7.

(b) $\mathrm{T} 100 \mathrm{P}=100$-poise temperature; ECT100P = electrical conductivity at $100-p o i s e$ temperature; $V 1330=$ viscosity at $1330^{\circ} \mathrm{C}$; and $E C 1330=$ electrical conductivity at $1330^{\circ} \mathrm{C}$. 
IABLE 7. The Mixture Model Forms Considered $(a)$

Linear Scheffe: $b_{1} x_{1}+b_{2} x_{2}+b_{3} x_{3}{ }^{(b)}$

Quadratic Scheffe: $b_{1} x_{1}+b_{2} x_{2}+b_{3} x_{3}+b_{12} x_{1} x_{2}+b_{13} x_{1} x_{3}+b_{23} x_{2} x_{3}$

Special-Cubic Scheffe: $b_{1} x_{1}+b_{2} x_{2}+b_{3} x_{3}+b_{12} x_{1} x_{2}+b_{13} x_{1} x_{3}+b_{23} x_{2} x_{3}+b_{123} x_{1} x_{2} x_{3}$

Becker H2: $b_{1} x_{1}+b_{2} x_{2}+b_{3} x_{3}+b_{12} x_{1} x_{2} /\left(x_{1}+x_{2}\right)+b_{13} x_{1} x_{3} /\left(x_{1}+x_{3}\right)+b_{23} x_{2} x_{3} /\left(x_{2}+x_{3}\right)$

Becker H3: $b_{1} x_{1}+b_{2} x_{2}+b_{3} x_{3}+b_{12}\left(x_{1} x_{2}\right)^{0.5}+b_{13}\left(x_{1} x_{3}\right)^{0.5}+b_{23}\left(x_{2} x_{3}\right)^{0.5}$

$\approx$ Linear Scheffe with Inverse Terms: $b_{1} x_{1}+b_{2} x_{2}+b_{3} x_{3}+d_{1}\left[1 /\left(x_{1}+c\right)\right]+d_{2}\left[1 /\left(x_{2}+c\right)\right]+d_{3}\left[1 /\left(x_{3}+c\right)\right](c)$

Quadratic Scheffe with: $b_{1} x_{1}+b_{2} x_{2}+b_{3} x_{3}+b_{12} x_{1} x_{2}+b_{13} x_{1} x_{3}+b_{23} x_{2} x_{3}$

Inverse Terms

$$
+d_{1}\left[1 /\left(x_{1}+c\right)\right]+d_{2}\left[1 /\left(x_{2}+c\right)\right]+d_{3}\left[1 /\left(x_{3}+c\right)\right](c)
$$

Linear Log-Contrast: $b_{0}+b_{1} \log \left(x_{2} / x_{1}\right)+b_{2} \log \left(x_{3} / x_{1}\right)$

quadratic Log-Contrast: $b_{0}+b_{1} \log \left(x_{2} / x_{1}\right)+b_{2} \log \left(x_{3} / x_{1}\right)+b_{12}\left[\log \left(x_{2} / x_{1}\right)\right]\left[\log \left(x_{3} / x_{1}\right)\right]$

(a) A convenient reference for all models except the log contrast models is Cornell (1981). A reference for the $\log$ contrast models is Aitchison and Bacon-Shone (1984).

(b) The $x_{1}, x_{2}$, and $x_{3}$ denote the weight fractions of soil, $\mathrm{CaO}$, and $\mathrm{Na}_{2} \mathrm{O}$, respectively.

(c) A value of $c=0.005$ was used to avoid division by zero. 
family of power transformations $y^{\lambda}$, and graphically indicates the value of $\lambda$ that will provide the best fit for each property considered. The implementation of this technique is not covered in this report, but the property transformations that resulted from it are shown in Table 8.

Ordinary (unweighted) least squares was used to fit the quadratic Scheffe model to the transformed data for each property using the SAS (1985b) regression procedure, REG. The coefficients and their associated standard deviations for the fitted quadratic scheffe mixture models are shown in Table 9. Also shown in Table 9 are the $R^{2}$ values, which indicate the fraction of variation in the transformed property data explained by the fitted models. A value of 1.0 would indicate a perfect fit. The $R^{2}$ values are seen to be above 0.96 for $V 1330$ and above 0.98 for T100P, ECT10OP, and EC1330. These values indicate that the quadratic Scheffé model form explains most of the variation in the data.

Also given in Table 9 are indications of whether the fitted models have statisticaliy significant lack-of-fits, based on a statistical procedure that compares the variation in the data not explained by the fitted models to the variation in the replicate property measurements. It is seen that all four models have statistically significant lack-of-fits (at the $90 \%$ confidence leve1). Because of the high fraction of total variation explained by the fitted models, the lack-of-fits being statistically significant may not be of practical significance.

IABLE 8. Transformations Applied to Glasss Properties Prior to Fitting Final Quadratic Scheffe Mixture Models

$\begin{array}{ll}\text { Property } & \begin{array}{c}\text { Applied } \\ \text { Iransformation }\end{array} \\ \text { T100P } & 1 / T 100 P \\ \text { ECT100P } & (E C T 100 P) \star \star 0.5 \\ V 1330 & \ln (V 1330)\end{array}$

EC1330

$(\mathrm{EC} 1330) \star \star 0.5$ 
IABLE 9. Coefficients, Coefficient Standard Deviations, $R^{2}$, Values, and Indications of Statistically Significant Lack-of-Fits for the Quadratic Scheffe Mixture Models Fitted to Transformed Values of T100P, ECT100P, V1330, and EC1330 Using the Data from Tables 3 and 4

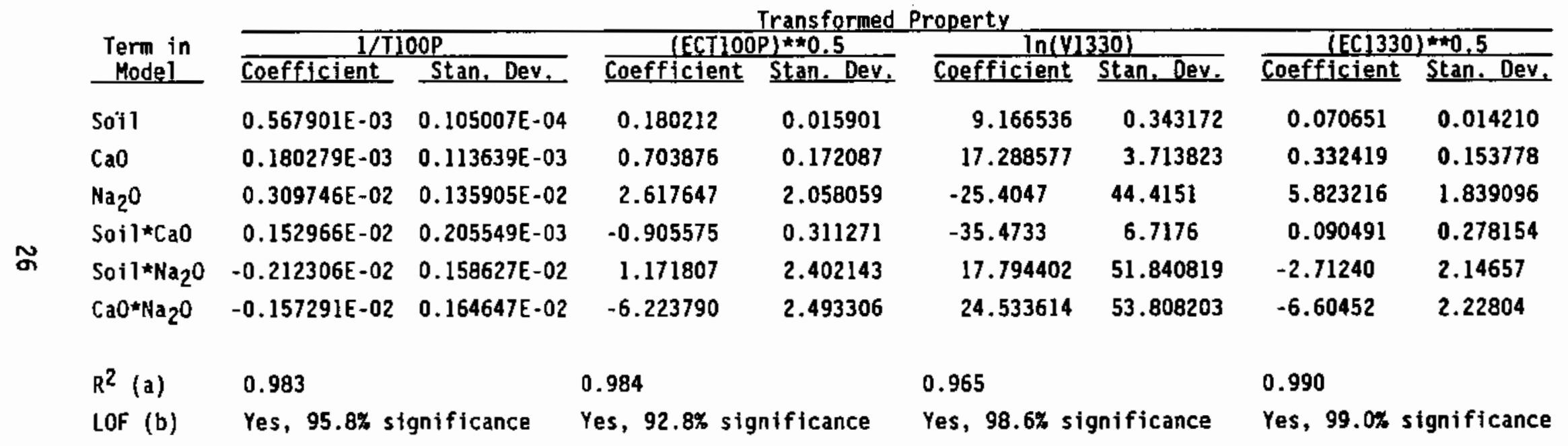

(a) $\mathrm{R}^{2}$ denotes the fraction of variation in the property (transformed, in this case) explained by the fitted mode1.

(b) Indication of statistical lack-of-fit and significance level. A statistically significant model lack-of-fit may or may not imply a practically significant lack-of-fit. 
First-order mixture models were also fit to the viscosity and electrical conductivity data using actual compositions of $\mathrm{Al}_{2} \mathrm{O}_{3}, \mathrm{SiO}_{2}, \mathrm{CaO}$, and $\mathrm{Na}_{2} \mathrm{O}$ as given in Table 5. However, because of the Timited number of data points, it was not possible to fit second-order mixture models. The first-order models had practically, as well as statistically, significant lack-of-fits, and hence are not reported here. It would be possible to fit partial secondorder mixture models to the actual composition data, but doing so was beyond the scope of the study and of questionable value given the small number of data points.

\section{PREDICTIONS AND PREDICTION CONFIDENCE INTERVALS WITH THE FITTED MODELS}

The fitted quadratic Scheffé models with coefficients given in Table 9 can be used to predict values of T100P, ECT100P, V1330, and EC1330 anywhere within the compositional region shown in Figure 1. Correspondingly, a 95\% confidence interval can be obtained for any such prediction, treating the prediction as a mean or as an individual observation. The formulas for computing these two types of $95 \%$ confidence intervals for predictions are given in Appendix C.

The use of the fitted quadratic Scheffe models and the $95 \%$ prediction confidence interval formulas from Appendix $C$ for the Tl00P model is described here. The predicted T100P value and the corresponding 95\% prediction confidence interval will be obtained for the mixture with soil $=0.65, \mathrm{Ca} 0=0.30$, and $\mathrm{Na}_{2} \mathrm{O}=0.05$. Note that the mixture is expressed in weight fractions rather than weight percentages, since that is how the model is expressed. Applying the fitted equation yields

$$
\begin{aligned}
& \text { Predicted TlO0P at soi }=0.65, \mathrm{CaO}=0.30, \text { and } \mathrm{Na}_{2}=0.05 \\
&= {[0.567901 \mathrm{E}-03(0.65)+0.180279 \mathrm{E}-03(0.30)+} \\
& 0.309746 \mathrm{E}-02(0.05)+0.152966 \mathrm{E}-02(0.65)(0.30)- \\
&0.212306 \mathrm{E}-02(0.65)(0.05)-0.157291 \mathrm{E}-02(0.30)(0.05)]^{-1}= \\
& {[0.783783 \mathrm{E}-03]^{-1}=1275.86^{\circ} \mathrm{C} }
\end{aligned}
$$


Note that because the fitted model directly predicts $1 / T 100 \mathrm{P}$, it was necessary to take the reciprocal of the predicted value to get a predicted T100P.

When the predicted value is treated as the prediction of a mean value, the standard deviation of the prediction in transformed units is given by Equation (C.1) in Appendix C:

$$
\begin{aligned}
\mathrm{SD}(\text { mean } 1 / \mathrm{T} 100 \mathrm{P}) & =\left[\mathbf{u}^{\prime}\left(\mathbf{U}^{\prime} \mathbf{U}\right)^{-1} \mathbf{u}\right]^{0.5} \cdot \hat{\sigma}(1 / \mathrm{T} 100 \mathrm{P}) \\
& =[0.228547]^{0.5} \cdot 0.155634 \mathrm{E}-04=0.744033 \mathrm{E}-05
\end{aligned}
$$

When the predicted value is treated as the prediction of an individual observation, the standard deviation of the prediction in transformed units is given by Equation (C.2) in Appendix C:

$$
\text { SD(indiv. } \begin{aligned}
1 / T 100 P) & =\left(1+\left[\mathbf{u}^{\prime}\left(\mathbf{U}^{\prime} \mathbf{U}\right)^{-1} \mathbf{u}\right]^{0.5}\right) \cdot \hat{\sigma}(1 / \mathrm{T} 100 \mathrm{P}) \\
& =(1+0.228547)^{0.5} \cdot 0.155634 \mathrm{E}-04 \\
& =0.172504 \mathrm{E}-04
\end{aligned}
$$

In Equations (1) and (2), $\mathbf{u}^{\prime}=\left(\begin{array}{lllll}0.65 & 0.30 & 0.05 & 0.65 \cdot 0.30 & 0.65 \cdot 0.05\end{array}\right.$ $0.30 \cdot 0.05)$, and $\left(\mathrm{U}^{\prime} U\right)^{-1}$ and $\hat{\sigma}(1 / \mathrm{T} 100 \mathrm{P})=0.155634 \mathrm{E}-04$ are given in Table $C .1$ of Appendix C.

If the prediction is treated as a mean value, the $95 \%$ confidence interval in transformed units is given by Equation (C.3) in Appendix C:

$$
\begin{aligned}
95 \% \mathrm{CI}(\text { mean } 1 / \mathrm{T} 100 \mathrm{P}) & =0.783783 \mathrm{E}-03 \pm 2.306(0.744033 \mathrm{E}-05) \\
& =[0.766626 \mathrm{E}-03,0.800940 \mathrm{E}-04]
\end{aligned}
$$

and in origina] units by

$$
\begin{aligned}
95 \% \mathrm{CI}(\text { mean T100P) } & =[1 / 0.800940 \mathrm{E}-04,1 / 0.766626 \mathrm{E}-03] \\
& =[1249,1304]
\end{aligned}
$$

If the prediction is treated as an individual observation, the $95 \%$ confidence interval in transformed units is given by Equation (C.4) in Appendix C: 


$$
\begin{aligned}
& 95 \% \mathrm{CI} \text { (indiv. } \mathrm{l} / \mathrm{T} 100 \mathrm{P})=0.783783 \mathrm{E}-03 \pm 2.306(0.172504 \mathrm{E}-04) \\
& =[0.744004 \mathrm{E}-03,0.823562 \mathrm{E}-03]
\end{aligned}
$$

and in original units by

$$
\text { 95\% } \begin{aligned}
\mathrm{CI} \text { (indiv. T100P) } & =[1 / 0.823562 \mathrm{E}-04,1 / 0.744004 \mathrm{E}-03] \\
& =[1214,1344]
\end{aligned}
$$

Note that the $95 \%$ confidence interval for the prediction treated as a single observation, $\left[1214^{\circ} \mathrm{C}, 1344^{\circ} \mathrm{C}\right]$, is wider than when the prediction is treated as a mean value, $\left[1249^{\circ} \mathrm{C}, 1304^{\circ} \mathrm{C}\right]$. This is because of the additional uncertainty in individual observations.

Similar steps to those above would be taken to make predictions or compute $95 \%$ confidence intervals for predictions from any of the other three fitted property models.

\section{CONTOUR AND COMPONENT EFFECTS PLOTS FROM THE FITTED MIXTURE MODELS}

In order to better understand the effect of composition (soil, $\mathrm{Ca} 0$, and $\mathrm{Na}_{2} \mathrm{O}$ weight fractions) on the properties investigated (T100P, ECT100P, V1330, and $E(1330)$, the fitted quadratic Scheffe mixture models were used to produce the contour plots given in Figures 7 through 10 and the component effects plots given in Figures 12 through 15. The GCDNTOUR procedure in SAS (1985b) was used to produce the contour plots, while the EFFPLT routine in MIXSDFT (Piepel 1989) along with the GPLOT procedure in SAS (1985a) were used to produce the effects plots.

The contour plots in Figures 7 through 10 merely show levels of constant property values over the composition space. The effects plots in Figures 12 through 15 are "traces" of property predictions along the effect directions shown in Figure 11. Note that the contour and effects plots*are in terms of the original (untransformed) property units. 


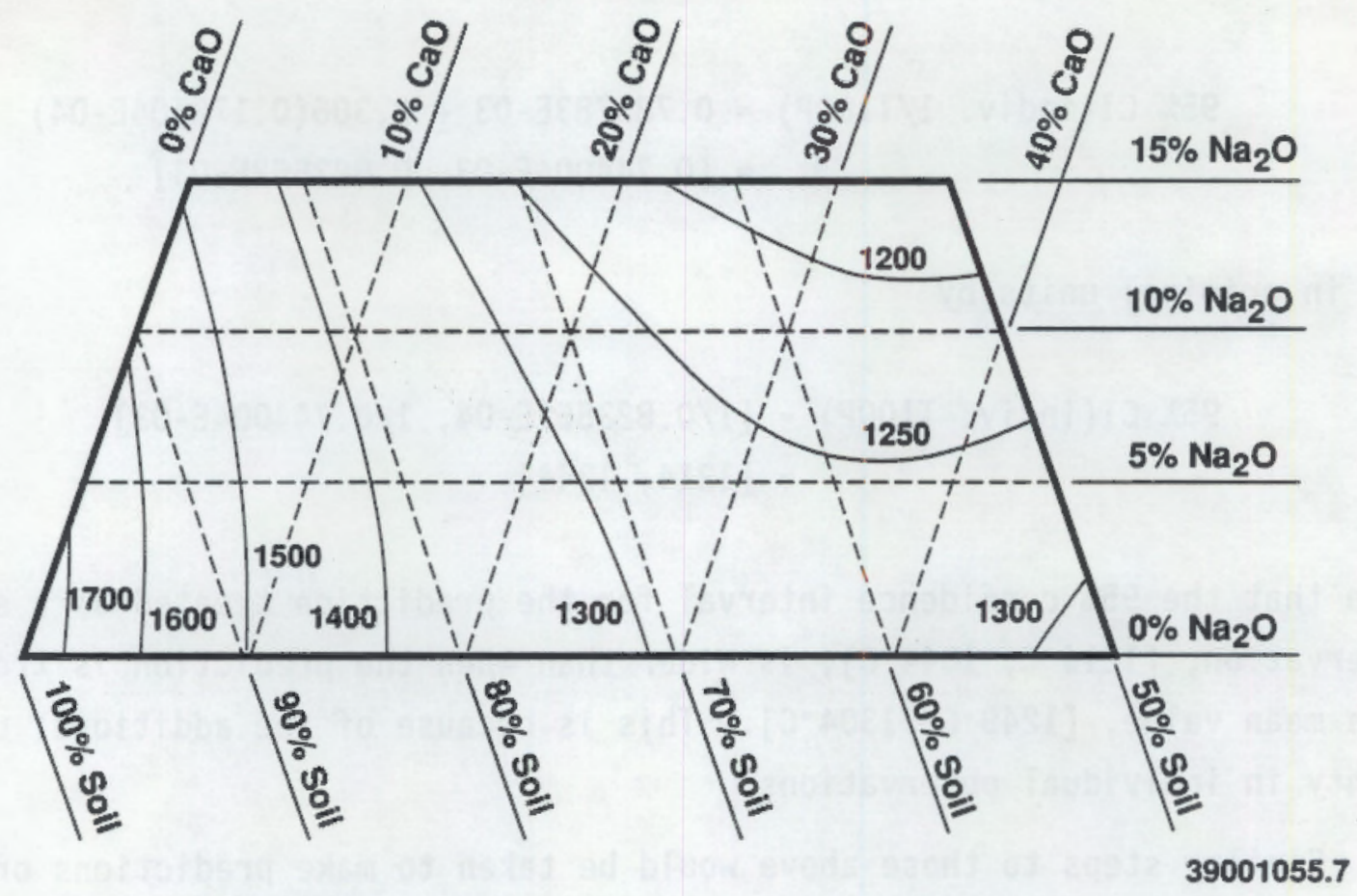

FIGURE 7. Contour Plot for TIOOP

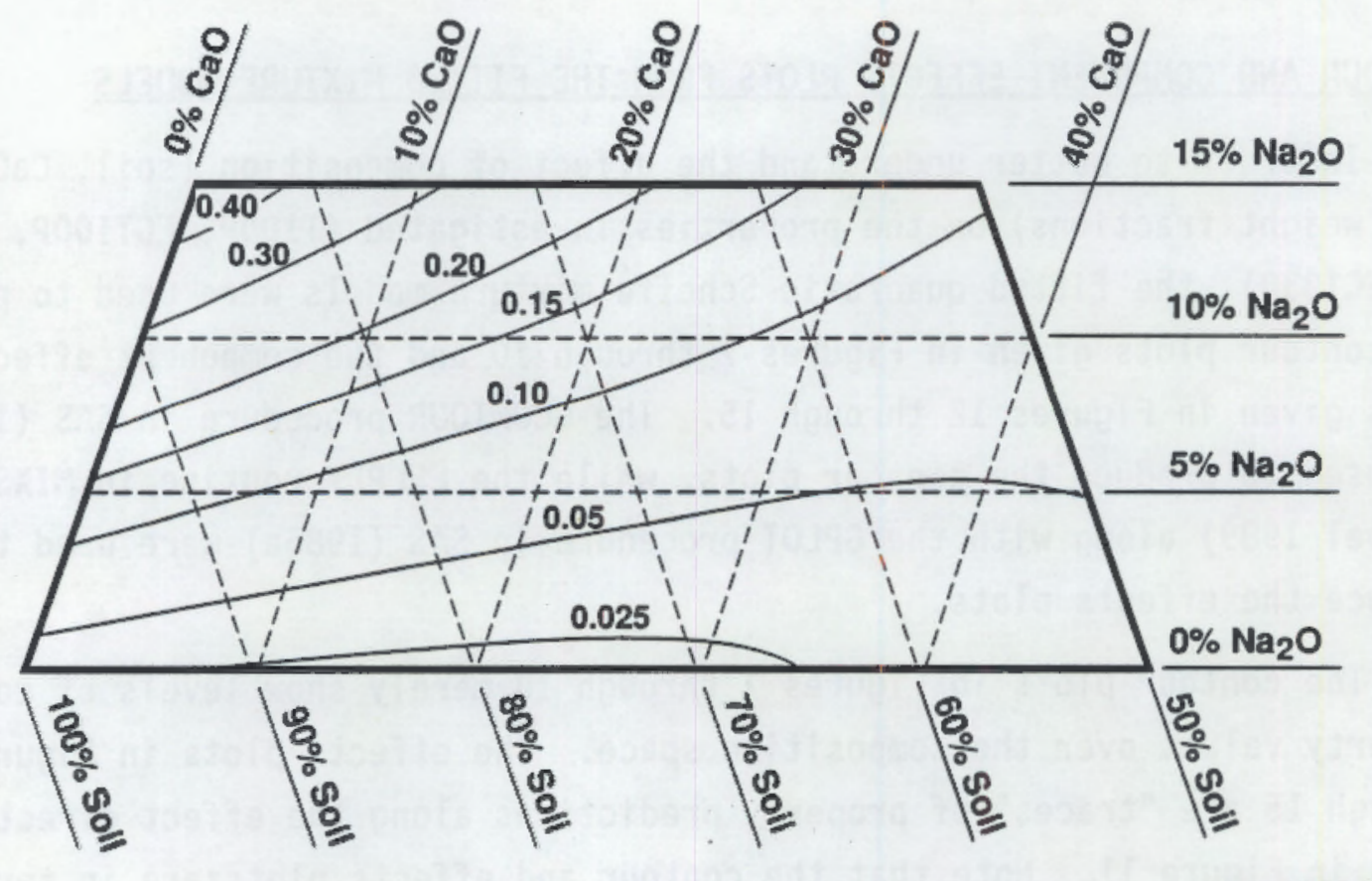

FIGURE 8. Contour Plot for ECTIOOP

30 


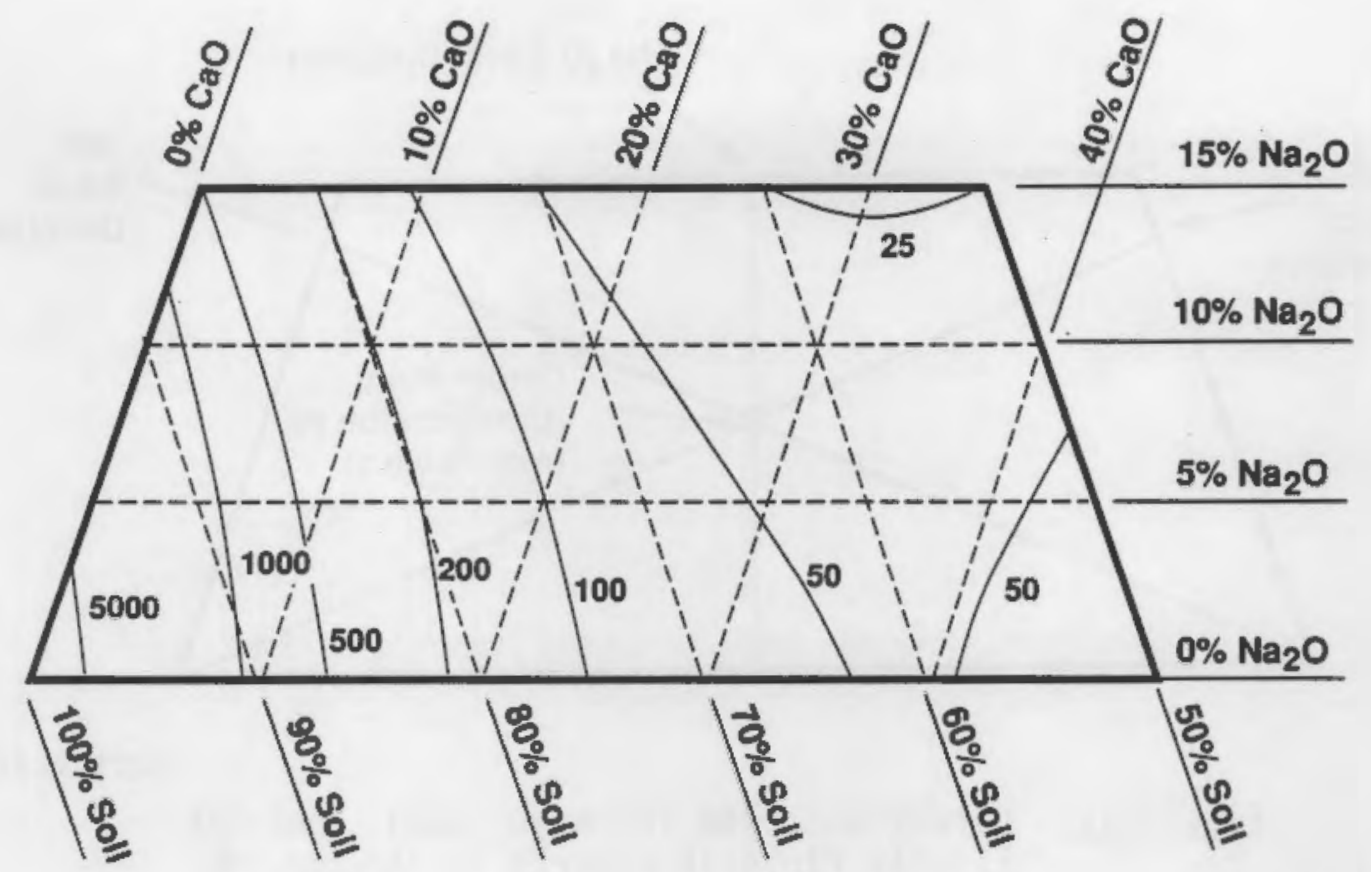

39001055.9

FIGURE 9. Contour Plot for V1330

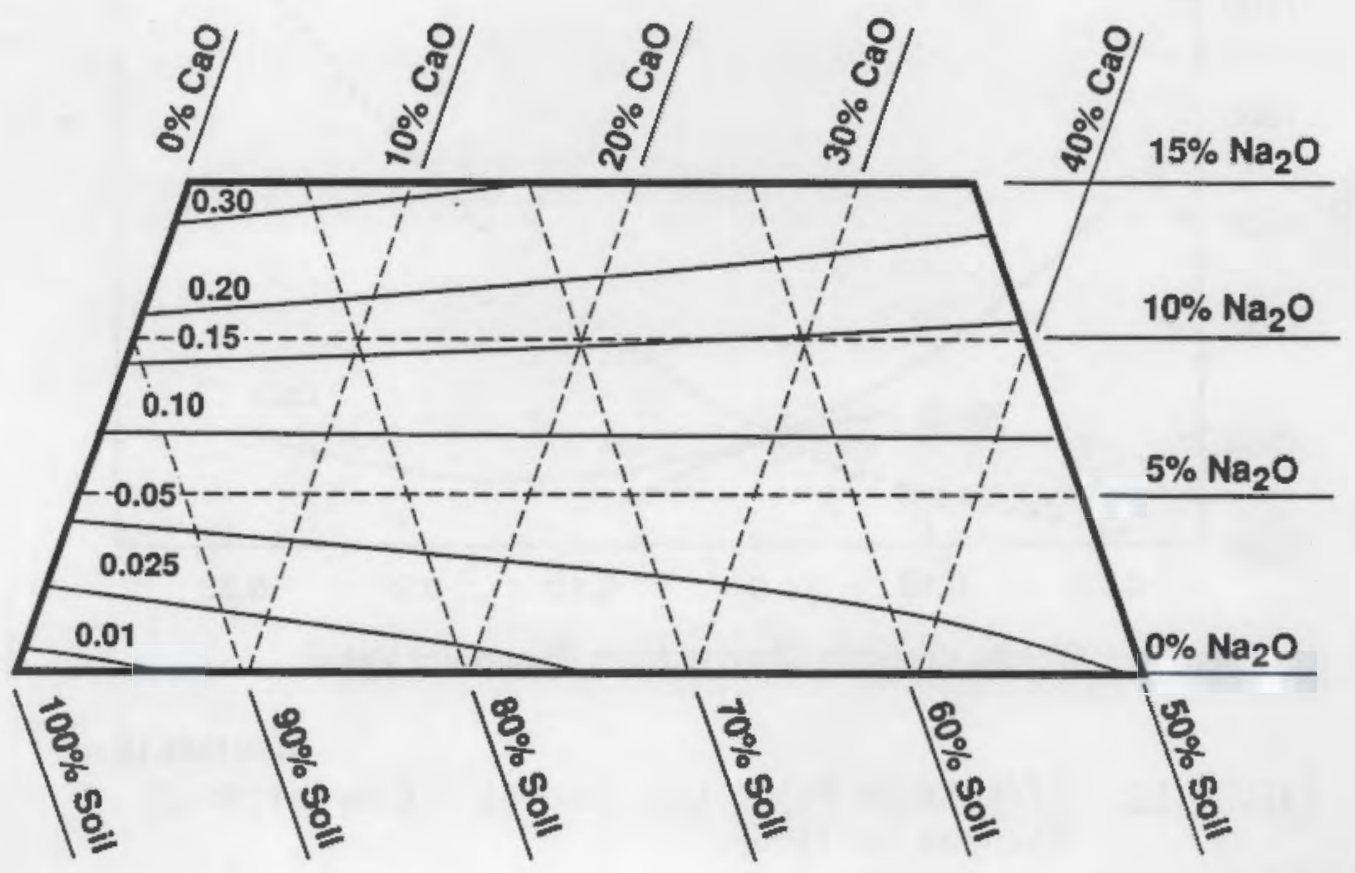

FIGURE 10. Contour Plot for EC1330 


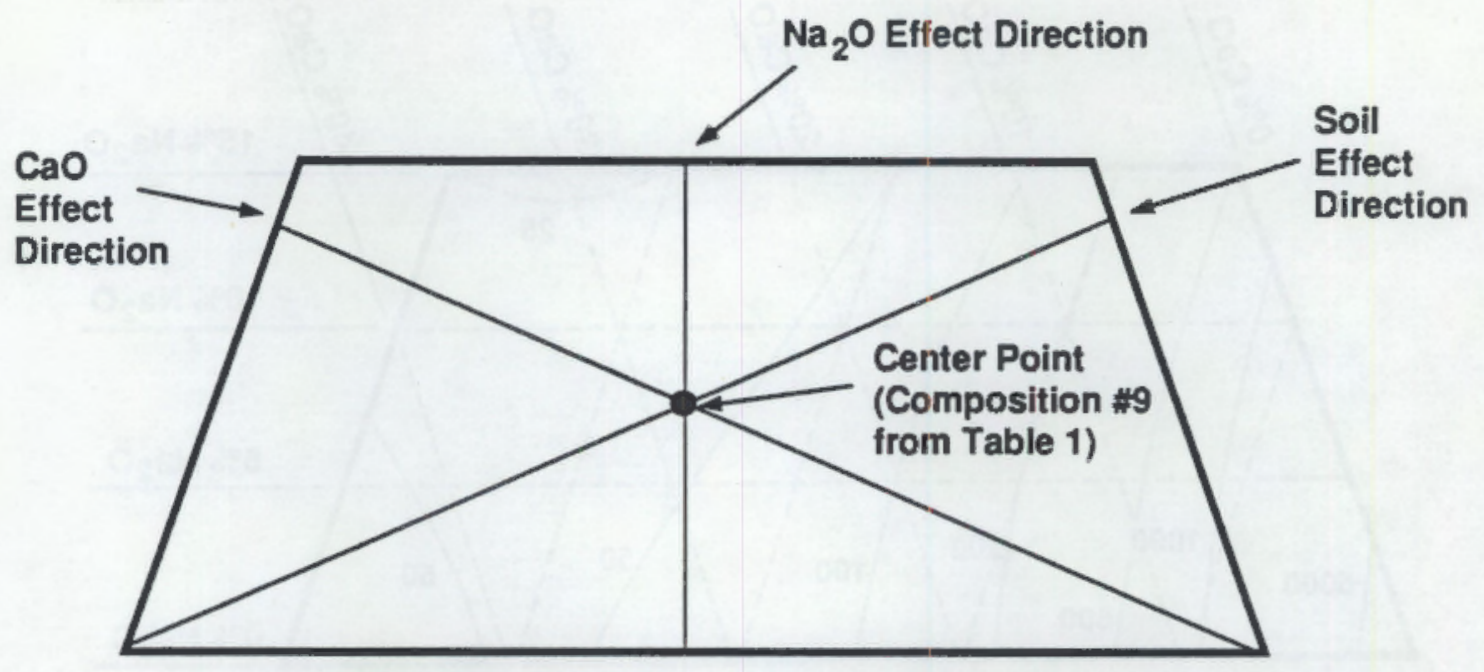

39001055.11

FIGURE 11. Directions Used for $\mathrm{Na}_{2} \mathrm{O}$, Soil, and $\mathrm{CaO}$

Effects Plots in Figures 12 through 15

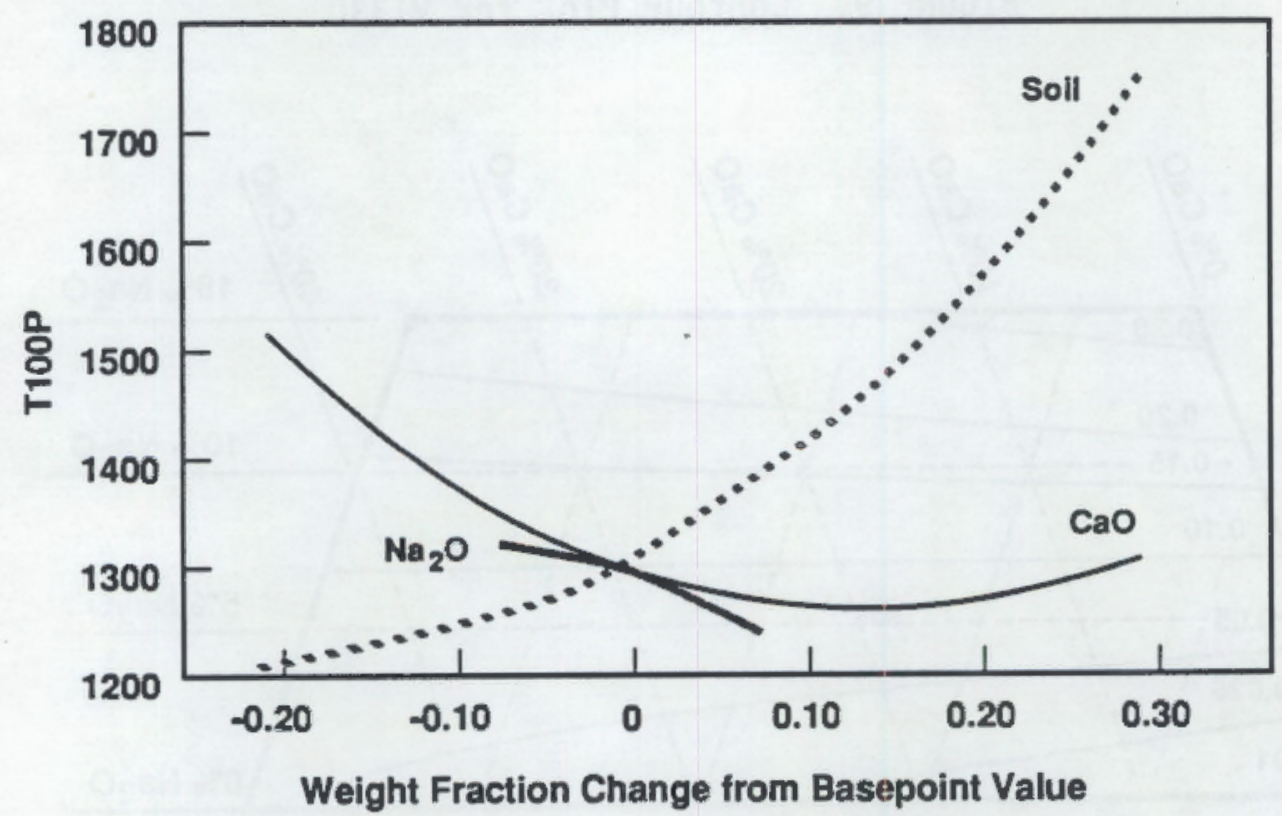

39001055.15

FIGURE 12. Effects of $\mathrm{Na}_{2} \mathrm{O}, \mathrm{CaO}$, and Soil Compositional Changes on T10OP 


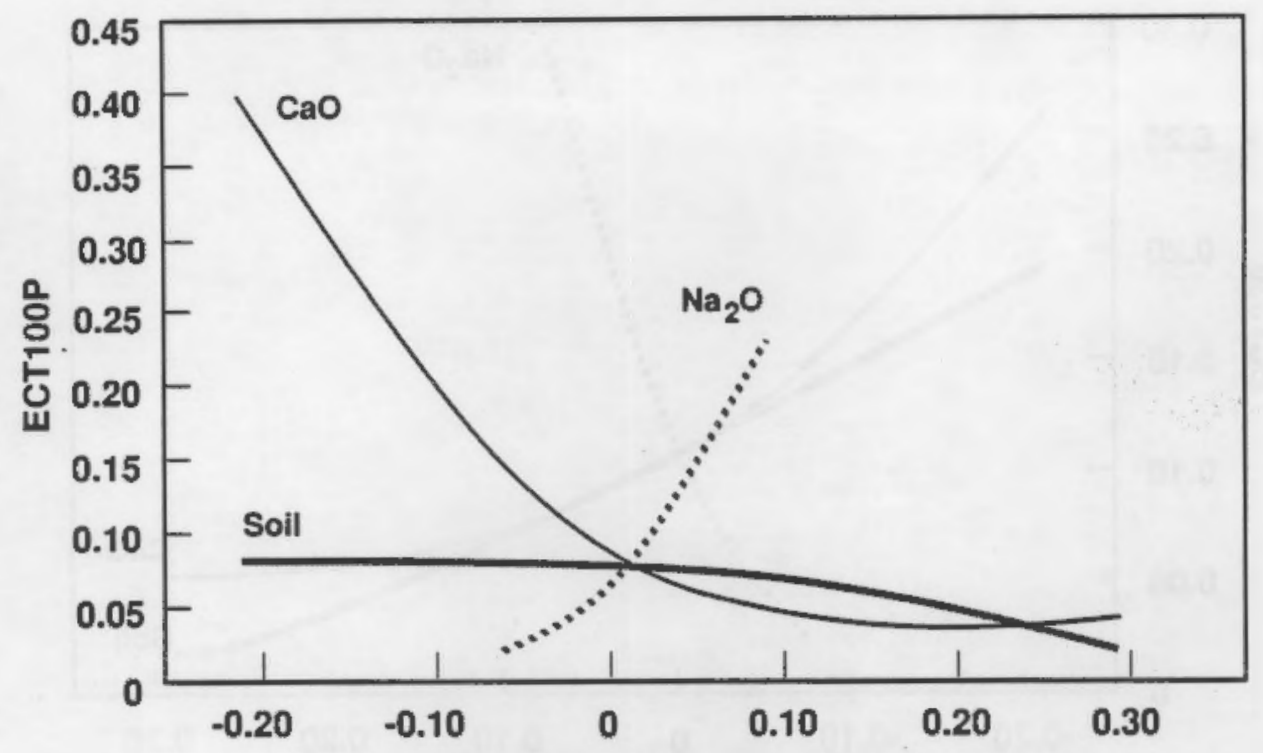

Weight Fraction Change from Basepoint Value

39001055.13

FIGURE 13. Effects of $\mathrm{Na}_{2} \mathrm{O}, \mathrm{CaO}$, and Soil Compositional Changes on Electrical Conductivity at T100P

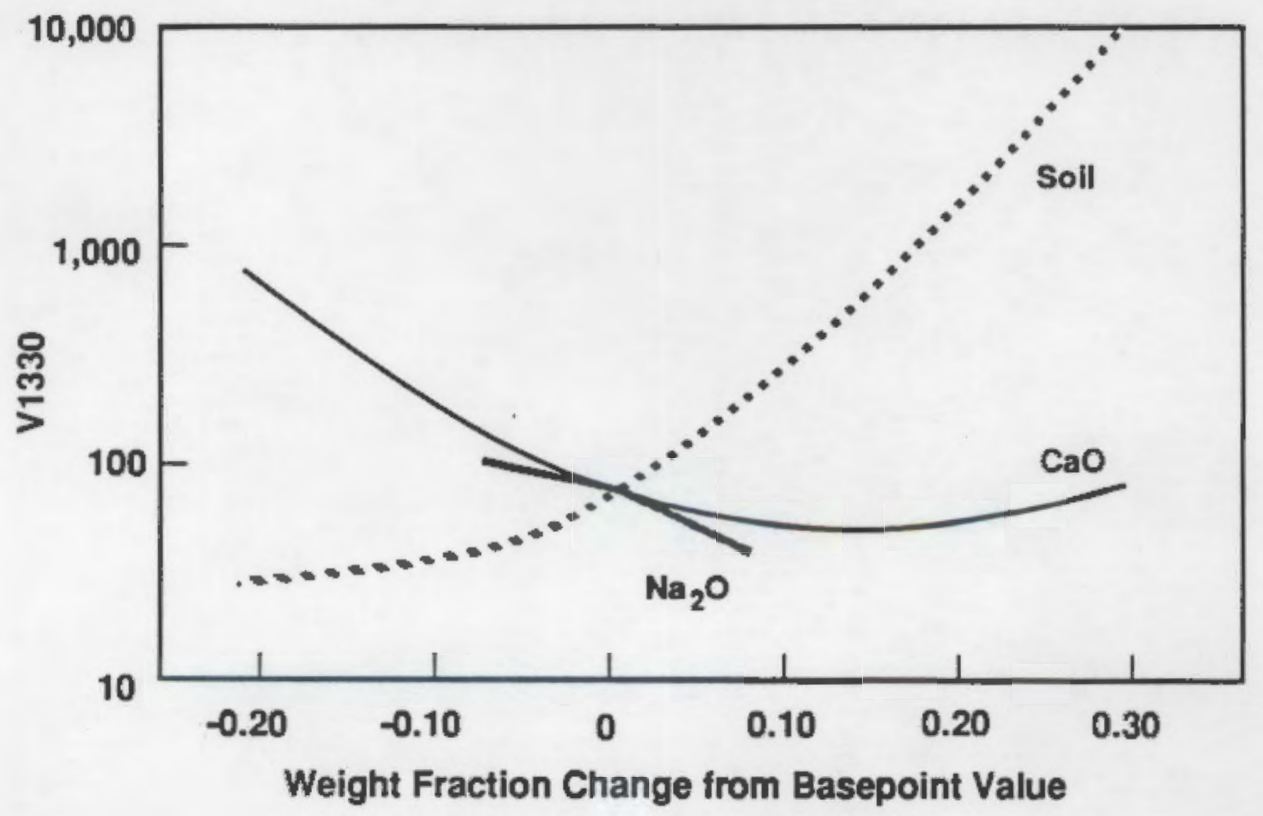

39001055.14

FIGURE 14. Effects of $\mathrm{Na}_{2} \mathrm{O}, \mathrm{CaO}$, and Soil Compositional Changes on Viscosity at $1330^{\circ} \mathrm{C}$ 


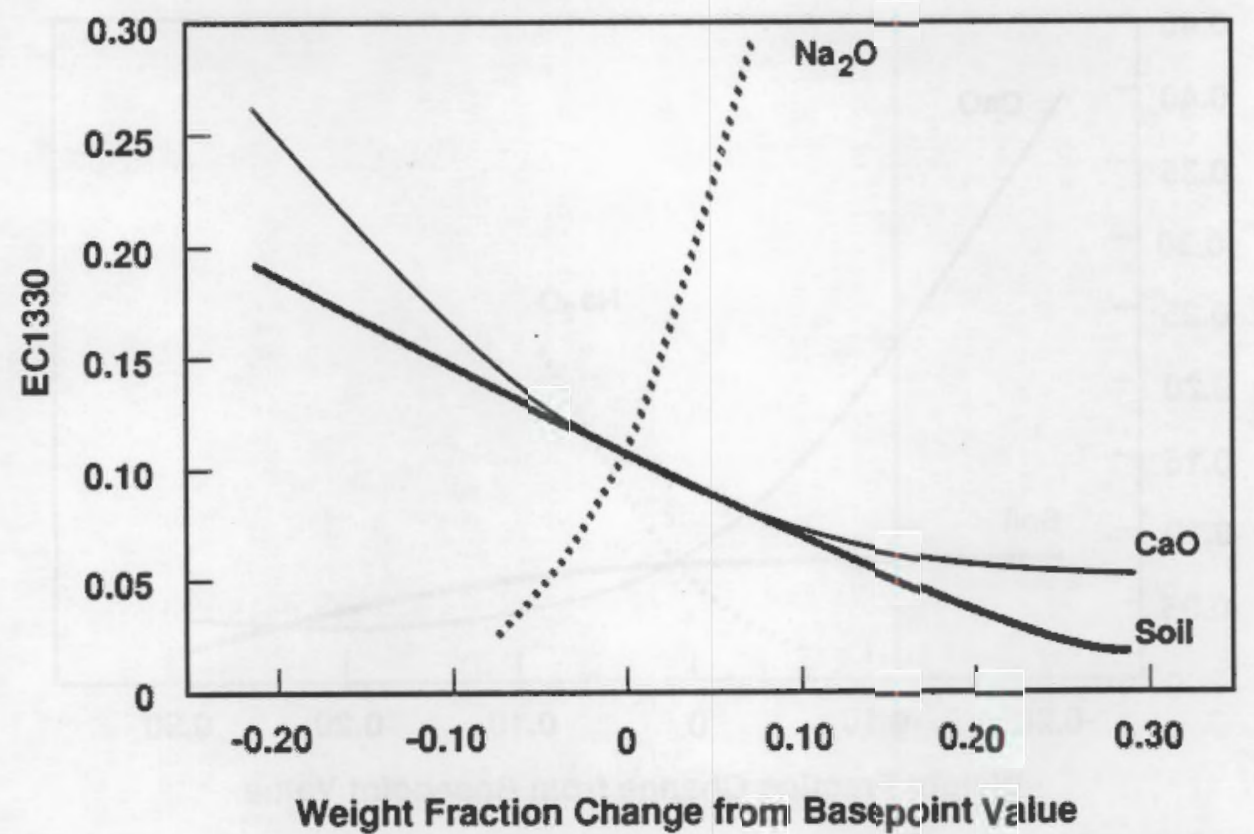

39001055.12

FIGURE 15. Effects of $\mathrm{Na}_{2} \mathrm{O}, \mathrm{CaO}$, and Soil Compositional Changes on Electrical Conductivity at $1330^{\circ} \mathrm{C}$ 


\section{CONCLUSIONS}

The following conclusions about the effects of soil, $\mathrm{CaO}$, and $\mathrm{Na}_{2} \mathrm{O}$ on the properties of viscosity and electrical conductivity can be made based on the contour plots in Figures 7 through 10 and the effects plots in Figures 12 through 15. A component having a positive (or negative) effect means that as the weight fraction of the component increases, the property increases (or decreases).

- The soil weight fraction of a glass has 1) a strong positive effect on T100P and V1330, 2), almost no effect on ECT100P, and 3) a negative effect on EC1330.

- The $\mathrm{Na}_{2} \mathrm{O}$ weight fraction of a glass has 1) almost no effect on T100P and V1330 when the glass is nearly all soil, but a minor negative effect for glasses containing less soil and more $\mathrm{CaO}$, and 2) a strong positive effect on ECTI00P and a very strong positive effect on EC1330.

- The Ca0 weight fraction of a glass has 1) negative effects on TIOOP, ECTIOOP, and V1330 when $0 \leq \mathrm{Ca} 0 \leq 25 \%$, but almost no effect when $25 \% \leq \mathrm{CaO} \leq 50 \%$, and 2) a negative effect on $\mathrm{EC} 1330$ when $0 \leq$ $\mathrm{CaO} \leq 35 \%$, but a 7 most no effect when $35 \% \leq \mathrm{CaO} \leq 50 \%$.

It is possible that the apparent lack of effect of $\mathrm{CaO}$ concentrations greater than $25 \%$ on viscosity may be due in part to crucible-melt reactions. These reactions tended to produce melts with fairly uniform $\mathrm{CaO} / \mathrm{SiO}_{2}$ ratios, which could in turn result in relatively similar viscosities. The $\mathrm{CaO} / \mathrm{SiO}_{2}$ ratios of the melts with greater than $25 \% \mathrm{Ca} 0$ were lower than expected based on initial mixtures of components. As a resuit, viscosities predicted by the model for these compositions may be higher than would actually occur in the absence of crucible-melt reactions.

The effects of temperature and viscosity on Cs volatitity are not a linear function of soil concentration as might be expected. The lowest Cs volatility of $0.12 \%$ occurred in a $\mathrm{Na}_{2} \mathrm{O}$-free composition of $75 \%$ so $11-25 \%$ $\mathrm{Ca} 0-0 \% \mathrm{Na}_{2} \mathrm{O}$. Between $1200^{\circ} \mathrm{C}$ and $1400^{\circ} \mathrm{C}$, the effect of temperature on CS vapor pressure at constant melt viscosity is small, resulting in a $C s$ volatility difference of 0.64 wt\% between the two temperatures. At a constant 
temperature of $1330^{\circ} \mathrm{C}$, the Cs volatility difference is $1.18 \mathrm{wt} \%$ between viscosities of 25 and 316 poises. These results suggest that the effect of viscosity on Cs diffusion through the melt may be more influential than the vapor pressure effect. 


\section{REFERENCES}

Aitchison, J., and J. Bacon-Shone. 1984. "Log Contrast Models for Experiments with Mixtures." Biometrika 71:323-330.

Box, G. E. P., and N. R. Draper. 1987. Empirical Model-Building and

Response Surfaces, John Wiley and Sons, New York.

Carter, J. G., S. 0, Bates, and G. D. Maupin. 1987. In-Situ Vitrification of Oak Ridge National Laboratory Soil and Limestone. PNL-6174, Pacific Northwest Laboratory, Richland, Washington.

Carter, J. G., S. S. Koegler, and S. 0. Bates. 1988. Process Performance of the Pilot-Scale In Situ Vitrification of a Simulated Waste Disposal Site at the 0ak Ridge National Laboratory. PNL-6530, Pacific Northwest Laboratory, Richland, Washington.

Corne11, J. A. 1981. Experiments with Mixtures: Designs, Models, and the Analysis of Mixture Data, John Wiley and Sons, New York.

Piepel, G. F. 1989. MIXSOFT and MIXSOFT USER'S GUIDE, Version 1.0, MIXSOFT--Mixture Experiment Software, Richland, Washington.

SAS. 1985a. SAS/GRAPH User's Guide, Version 5 Edition, SAS Institute Inc., Cary, North Carolina.

SAS. 1985b. SAS User's Guide: Statistics, Version 5 Edition, SAS Institute Inc., Cary, North Carolina.

Spalding, B. P. 1989. Volatilization and Leachability of Cesium from Vitrified Soils with Sodium and Limestone Amendments. ORNL-RAP/LTR-89/19, 0ak Ridge National Laboratory, Oak Ridge, Tennessee.

Spalding, B. P., and G. K. Jacobs. 19B9. "Field Demonstration of In-Situ Vitrification for Application to ORNL Liquid Waste Disposal Trenches." In Proceedings of the 1988 DOE Model Conference, CONF-881054, Vo1. 4, pp. 14031413, Martin Marietta Energy Systems, Inc., Oak Ridge, Tennessee. 
$\therefore$

$-$ . 
APPENDIX A

COMPARISON OF TARGET AND ACTUAL MELT COMPOSITIONS 
IABLE A-1. Comparison of Target ( $T$ ) and Actual (A) Melt Compositions for ORNL/ISV Mixtures (wt\%)

Oxide

$\mathrm{Al}_{2} \mathrm{O}_{3}$

$\mathrm{SiO}_{2}$

$\mathrm{CaO}$

Mg0

$\mathrm{Fe}_{2} \mathrm{O}_{3}$

$\mathrm{K}_{2} \mathrm{O}$

$\mathrm{Na}_{2} \mathrm{O}$

Oxide

$\mathrm{Al}_{2} \mathrm{O}_{3}$

$\mathrm{SiO}_{2}$

$\mathrm{CaO}$

MgO

$\mathrm{Fe}_{2} \mathrm{O}_{3}$

$\mathrm{K}_{2} \mathrm{O}$

$\mathrm{Na}_{2} \mathrm{O}$

Oxide

$\mathrm{Al}_{2} \mathrm{O}_{3}$

$\mathrm{SiO}_{2}$

$\mathrm{CaO}$

Mgo

$\mathrm{Fe}_{2} \mathrm{O}_{3}$

$\mathrm{K}_{2} \mathrm{O}$

$\mathrm{Na}_{2} \mathrm{O}$

\begin{tabular}{|c|c|c|c|c|c|}
\hline & & \multicolumn{2}{|c|}{$\frac{\text { aposition }}{2}$} & \multicolumn{2}{|c|}{3} \\
\hline $\mathrm{I}$ & $A$ & $I$ & A & $\mathrm{T}$ & $A$ \\
\hline 16.3 & 18.4 & 13.8 & 15.5 & 8.2 & 9.4 \\
\hline 55.6 & 62.6 & 47.3 & 54.0 & 27.8 & 48.2 \\
\hline 5.4 & 5.9 & 4.6 & 4.1 & 37.7 & 24.7 \\
\hline 2.0 & 2.0 & 1.7 & 1.7 & 1.0 & 2.4 \\
\hline 5.6 & 6.2 & 4.8 & 5.2 & 2.8 & 2.6 \\
\hline 4.1 & 3.6 & 3.1 & 3.0 & 2.0 & 1.8 \\
\hline 1.3 & 1.2 & 16.1 & 15.4 & 15.6 & 11.0 \\
\hline
\end{tabular}

Composition

\begin{tabular}{|c|c|c|c|c|c|}
\hline \multicolumn{2}{|c|}{4} & \multicolumn{2}{|c|}{5} & \multicolumn{2}{|c|}{6} \\
\hline I & A & $\mathrm{I}$ & A & $I$ & A \\
\hline 8.2 & 9.3 & 15.1 & 17.8 & 12.2 & 13.6 \\
\hline 27.8 & 47.1 & 51.4 & 59.4 & 41.7 & 49.1 \\
\hline 52.7 & 34.2 & 5.0 & 2.4 & 29.1 & 25.6 \\
\hline 1.0 & 3.1 & 1.8 & 1.8 & 1.5 & 3.0 \\
\hline 2.8 & 2.7 & 5.2 & 5.8 & 4.2 & 4.5 \\
\hline 2.0 & 2.7 & 3.8 & 3.6 & 3.1 & 2.6 \\
\hline 0.6 & 0.7 & 8.7 & 8.4 & 1.0 & 1.0 \\
\hline
\end{tabular}

Composition

\begin{tabular}{|c|c|c|c|c|c|}
\hline \multicolumn{2}{|c|}{7} & \multicolumn{2}{|c|}{8} & \multicolumn{2}{|c|}{9} \\
\hline$I$ & $\mathrm{~A}$ & $\bar{T}$ & $A$ & $I$ & $\mathrm{~A}$ \\
\hline 8.2 & 9.6 & 11.0 & 12.4 & 11.6 & 12.9 \\
\hline 27.8 & 45.8 & 37.5 & 46.9 & 39.6 & 48.4 \\
\hline 43.2 & 30.0 & 21.1 & 17.2 & 25.1 & 21.2 \\
\hline 1.0 & 2.9 & 1.4 & 2.2 & 1.4 & 2.6 \\
\hline 2.8 & 2.8 & 3.8 & 3.9 & 4.0 & 4.3 \\
\hline 2.0 & 1.9 & 2.8 & 2.5 & 2.9 & 2.8 \\
\hline 8.1 & 6.1 & 15.9 & 14.1 & 8.4 & 7.5 \\
\hline
\end{tabular}


IABLE A-1. (contd)

\begin{tabular}{|c|c|c|c|c|c|c|}
\hline \multirow[b]{2}{*}{$\underline{\text { Oxide }}$} & \multicolumn{2}{|c|}{10} & \multicolumn{2}{|c|}{11} & \multicolumn{2}{|c|}{12} \\
\hline & $\mathrm{I}$ & A & $I$ & A & $T$ & A \\
\hline $\mathrm{Al}_{2} \mathrm{O}_{3}$ & 13.3 & 15.4 & 9.9 & 10.8 & 16.3 & 18.6 \\
\hline $\mathrm{SiO}_{2}$ & 45.5 & 52.4 & 33.7 & 49.8 & 55.6 & 63.0 \\
\hline $\mathrm{CaO}$ & 15.0 & 13.5 & 35.1 & 24.1 & 5.4 & 4.5 \\
\hline MgO & 1.6 & 2.3 & 1.2 & 2.6 & 2.0 & 2.0 \\
\hline $\mathrm{Fe}_{2} \mathrm{O}_{3}$ & 4.6 & 5.1 & 3.4 & 3.2 & 5.6 & 6.2 \\
\hline $\mathrm{K}_{2} \mathrm{O}$ & 3.3 & 3.1 & 2.5 & 2.0 & 4.1 & 3.8 \\
\hline $\mathrm{Na}_{2} \mathrm{O}$ & 8.6 & 8.3 & 8.3 & 6.3 & 1.3 & 1.3 \\
\hline
\end{tabular}

Oxide

$\mathrm{Al}_{2} \mathrm{O}_{3}$

$\mathrm{SiO}_{2}$

$\mathrm{Ca} 0$

$\mathrm{MgO}$

$\mathrm{Fe}_{2} \mathrm{O}_{3}$

$\mathrm{K}_{2} \mathrm{O}$

$\mathrm{Na}_{2} \mathrm{O}$

\begin{tabular}{|c|c|c|c|}
\hline \multicolumn{4}{|c|}{ Composition } \\
\hline $\mathrm{T}$ & $A$ & $T$ & $\vec{A}$ \\
\hline 8.2 & 9.6 & 11.6 & 13.0 \\
\hline 27.8 & 47.4 & 39.6 & 46.8 \\
\hline 37.7 & 24.7 & 25.1 & 21.2 \\
\hline 1.0 & 2.4 & 1.4 & 2.7 \\
\hline 2.8 & 2.6 & 4.0 & 4.3 \\
\hline 2.0 & 1.5 & 2.9 & 3.0 \\
\hline 15.6 & 11.0 & 8.4 & 7.9 \\
\hline
\end{tabular}




\section{APPENDIX B}

VISCOSITY AND ELECTRICAL CONDUCTIVITY EXPERIMENTAL DATA 


\section{APPENDIX B}

\section{VISCOSITY AND ELECTRICAL CONDUCTIVITY EXPERIMENTAL DATA}

The viscosity and electrical conductivity measurements presented in Appendix $B$ were obtained at a minimum of three temperatures for each of the soil-1imestone-sodium carbonate compositions. The methods of measurements are described in the text. The composition points given in the graphs in Appendix $B$ are listed in Table 1 of the text.

The $\log$ of the viscosity or electrical conductivity for each composition is plotted as a function of the reciprocal absolute temperature with the actual data used listed in each plot. A line was fit to these points by inspection, and viscosity or electrical conductivity values at specific temperatures (such as TIOOP or ECTIOOP) were obtained from this line. In most cases these specific temperature values were interpolated because actual measurements were normally made at temperatures including the temperature of interest. For compositions with greater than $90 \%$ soil, however, this was not possible because of high viscosities at lower temperature and a maximum furnace temperature $1 \mathrm{imit}$ of $1650^{\circ} \mathrm{C}$. In such cases, estimates of T100P and ECT100P were obtained by extrapolation. At composition 4 with $50-50$ soillimestone, only one reliable viscosity measurement could be obtained at $1399^{\circ} \mathrm{C}$. At the approximate T100P of $1327^{\circ} \mathrm{C}$, the melt viscosity changed with time because of crystallization and reaction with the crucible. The $1327^{\circ} \mathrm{C}$ value was obtained when the melt was most stable during this period. 


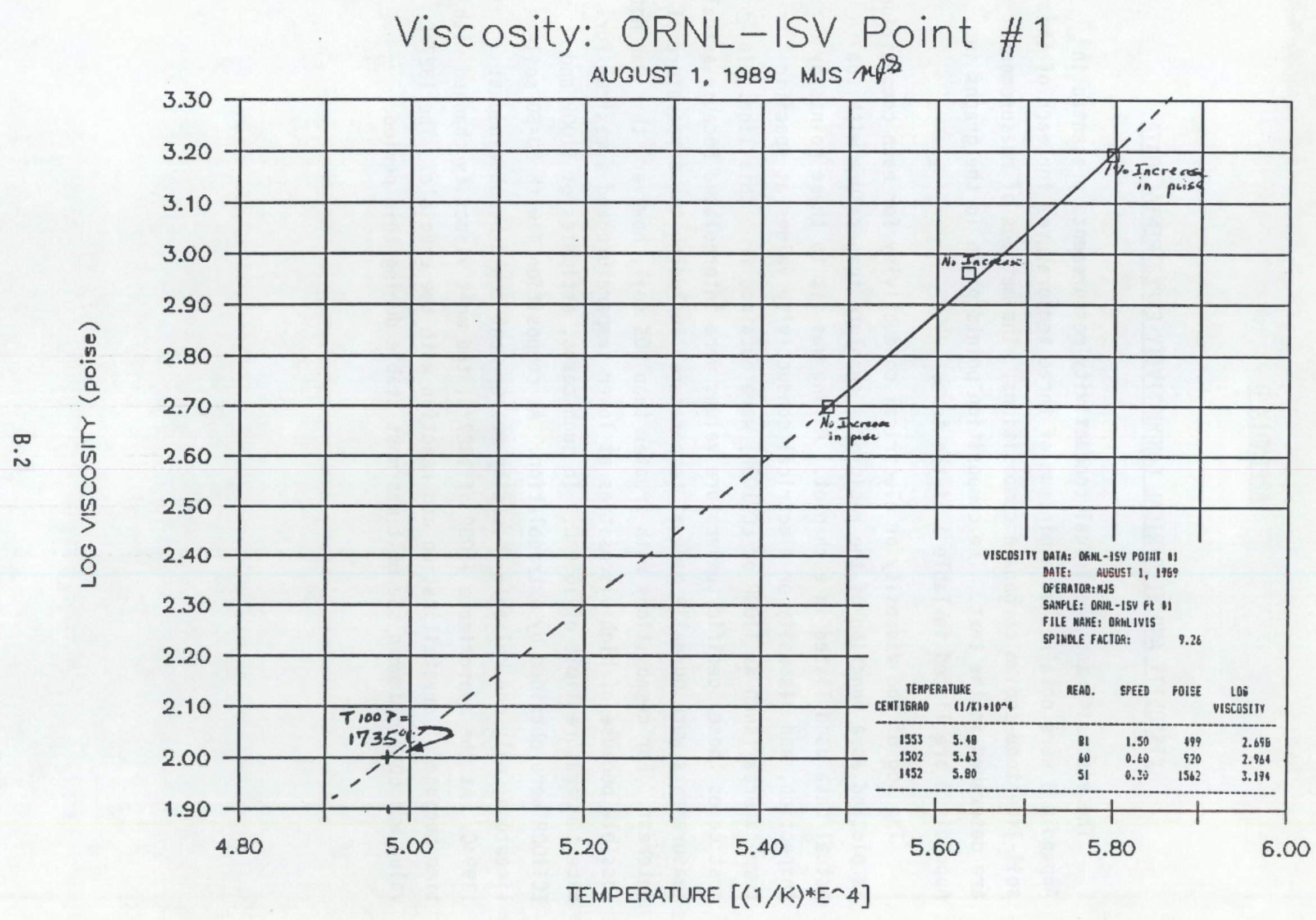




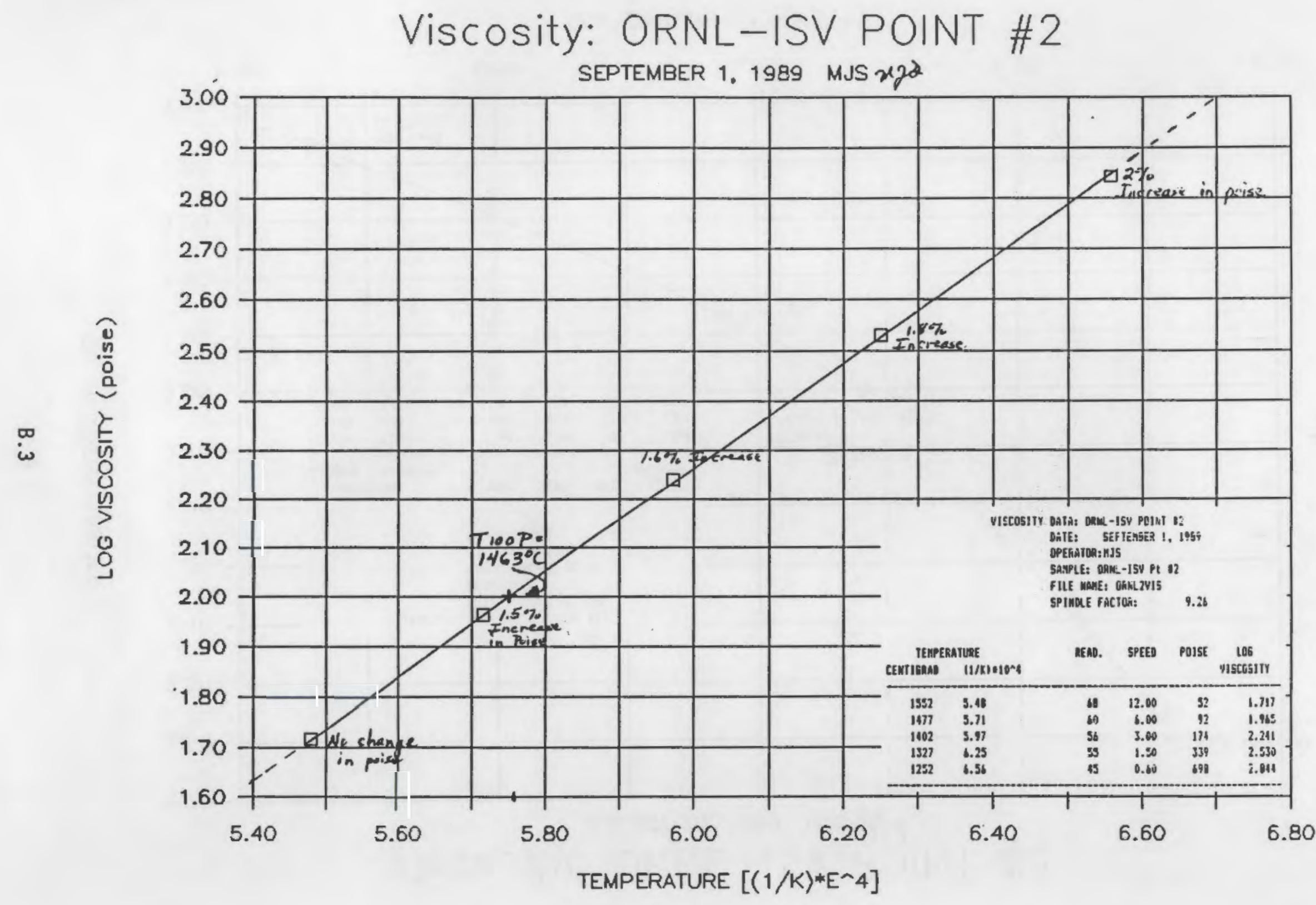




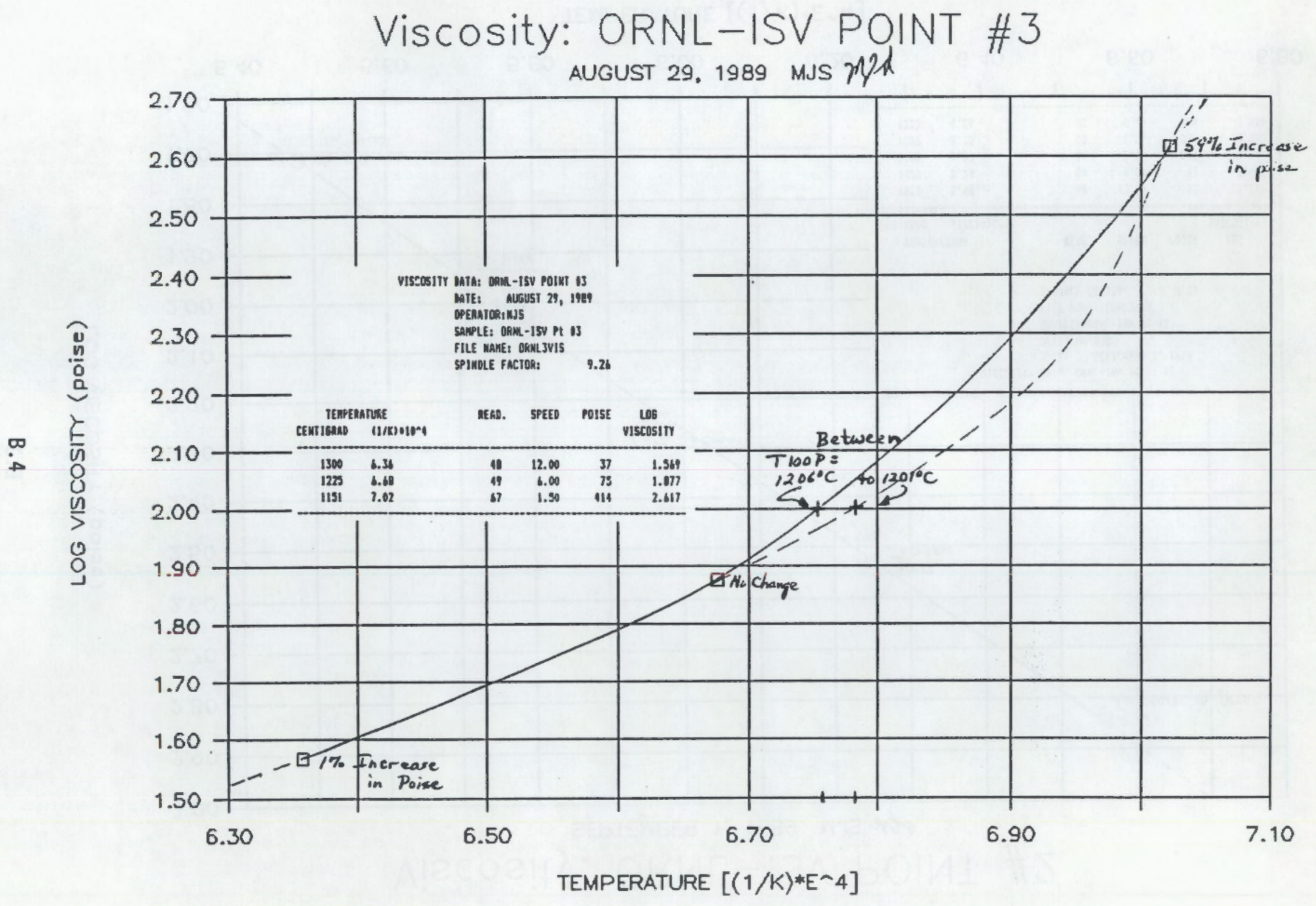




\section{VISCOSITY DATA: ORNL-ISV POIHT I4}

DATE: SEPTEMBER 11,1989

OPERATOR:MJS

SAHPLE: DRHL-ISV PL IA

FILE HAME: ORMLAVIS

SPIMDLE FACTOR: $\quad 9.26$

READ. SPEED

POISE

LOG

\begin{tabular}{|c|c|c|c|c|c|}
\hline CENTIERAD & $(1 / K)=10^{\wedge} 4$ & & & & Iscosity \\
\hline 1399 & 5.98 & 55 & 30.00 & 17 & \\
\hline
\end{tabular}

AT 1325C THE POISE COULD BE MEASURED AS 39 POISE AT IHE BEGIHAING OF

THE RUH, 6O POISE AT 12 MIHUTES AND 154 POISE AT 23 HIHUTES. THE TEMPERATURE

WAS THEH DKDFPED 75C, EUT THE POISE HAD RISEH BEYOHO THE CAPABILITY OF THE

VISCOHETER. BECPUSE OF THE IRRATIC NATURE DF THIS DATA, A GRAFH HOULO NOT

REFRESERT THIS DAIA ACCURATELY. 


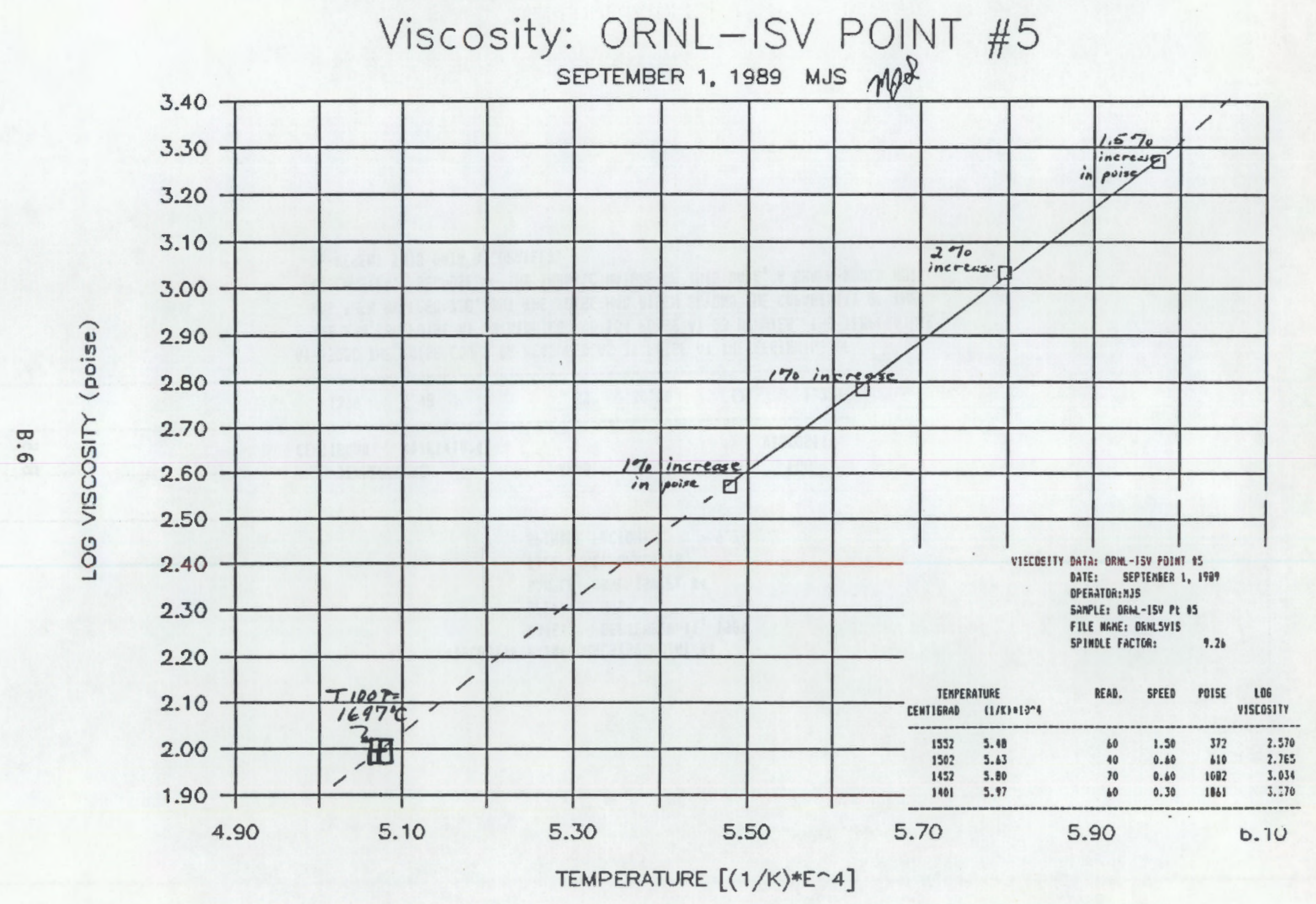




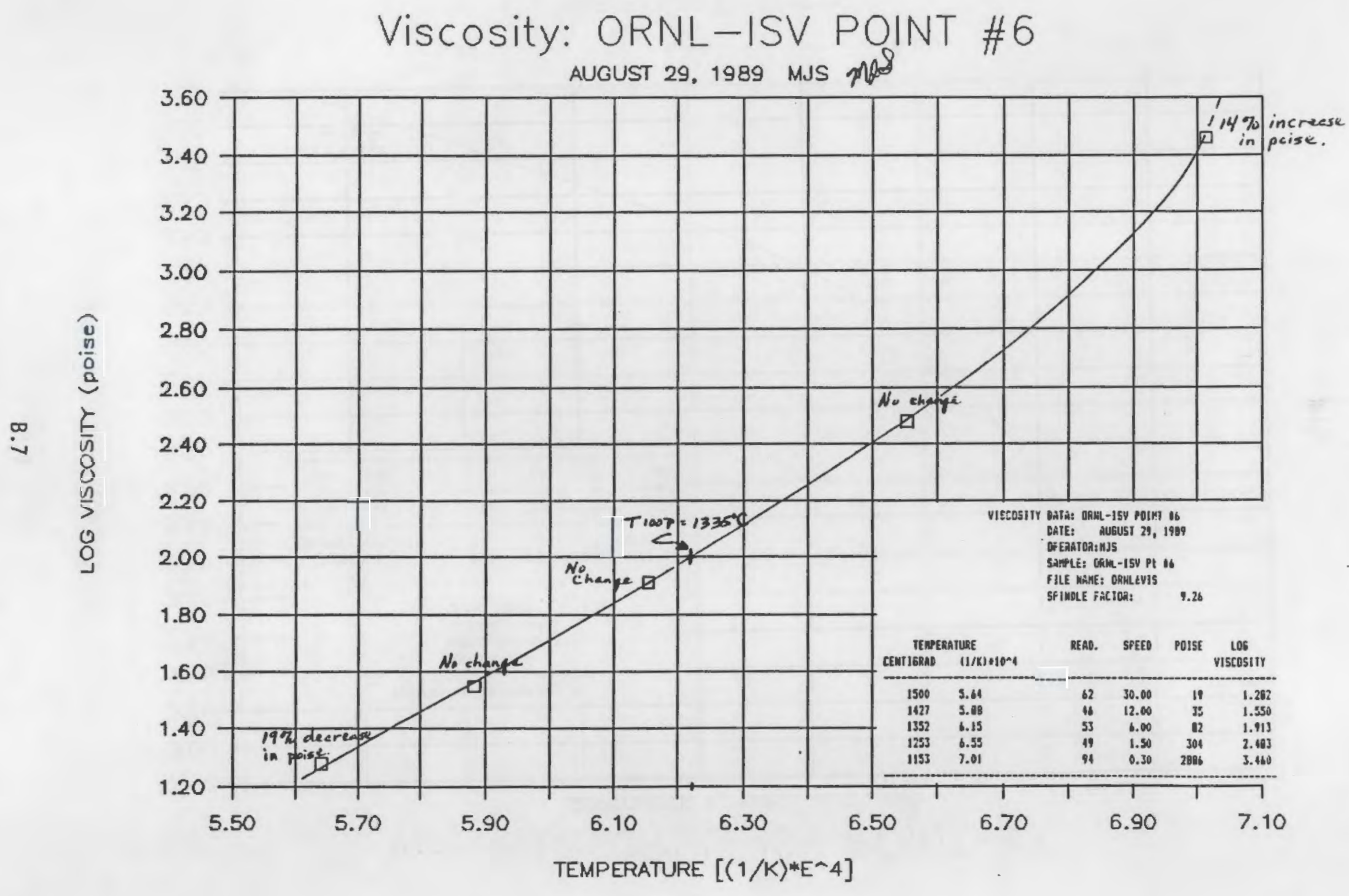




\section{Viscosity: ORNL-ISV POINT \#7 \\ SEPTEMBER 1. 1989 MJS MUd}

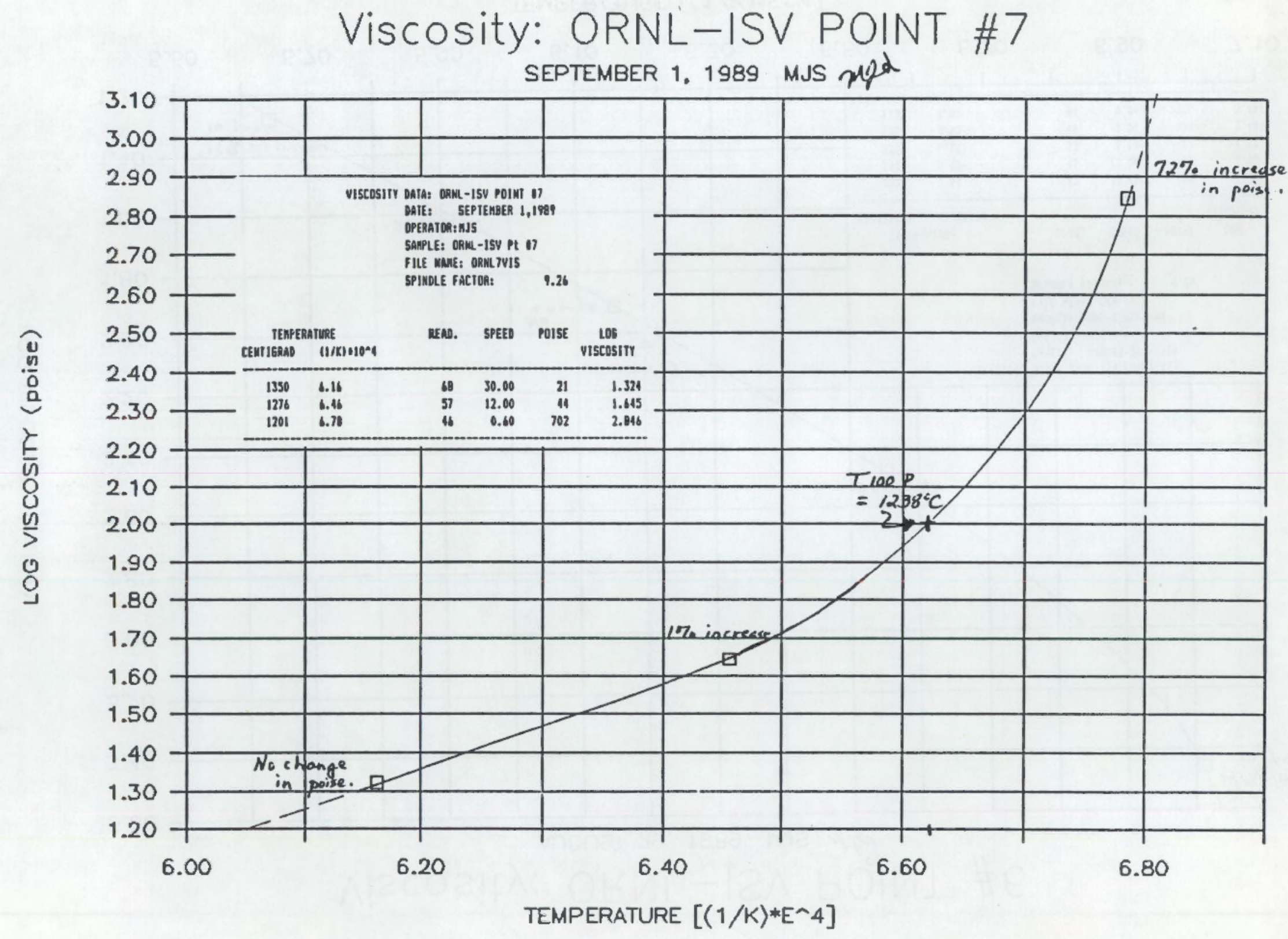




\section{Viscosity: ORNL-ISV POINT \#8}

SEPTEMBER 1. 1989 MJS $\mathrm{n}^{2} \mathrm{q}^{\mathrm{d}}$

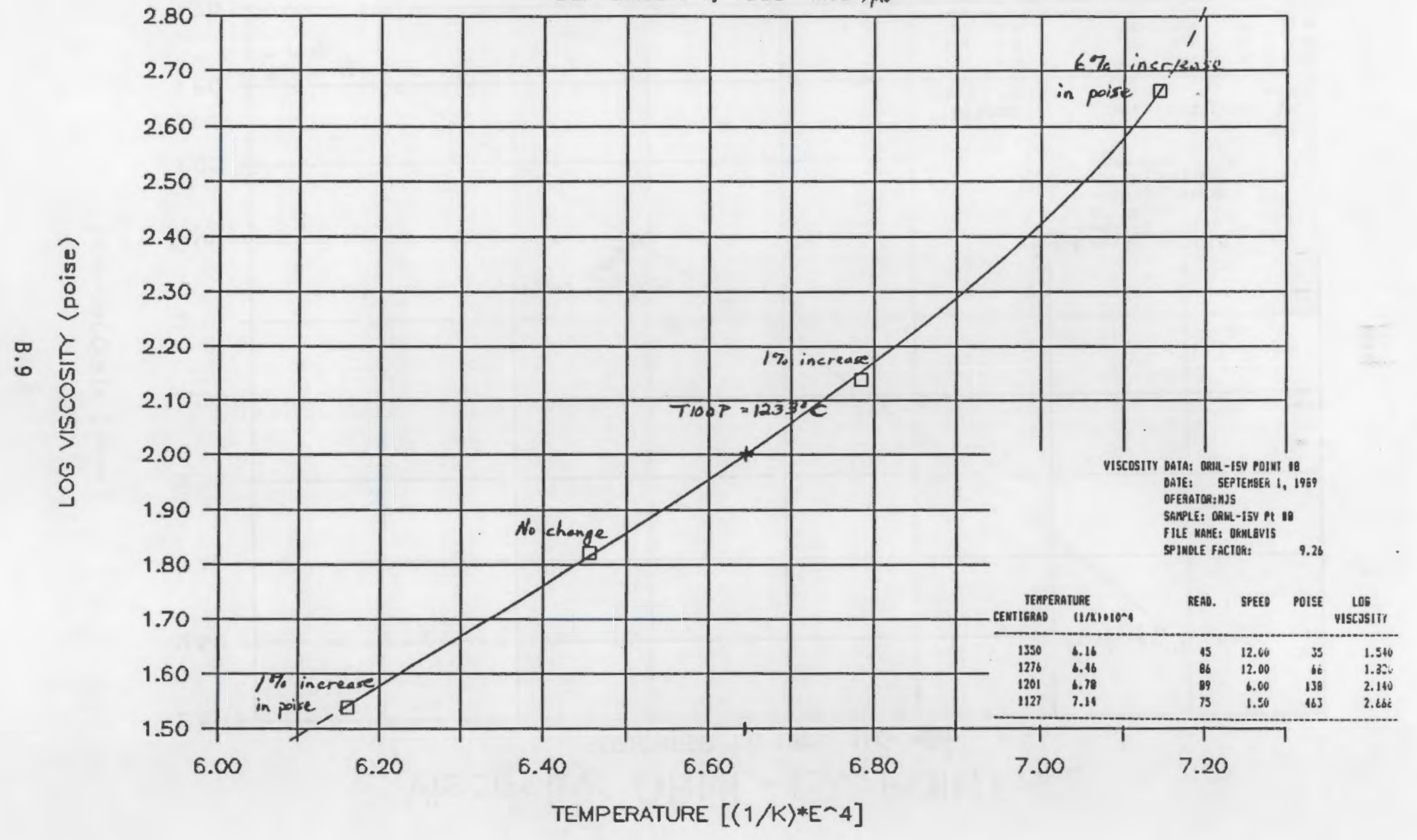




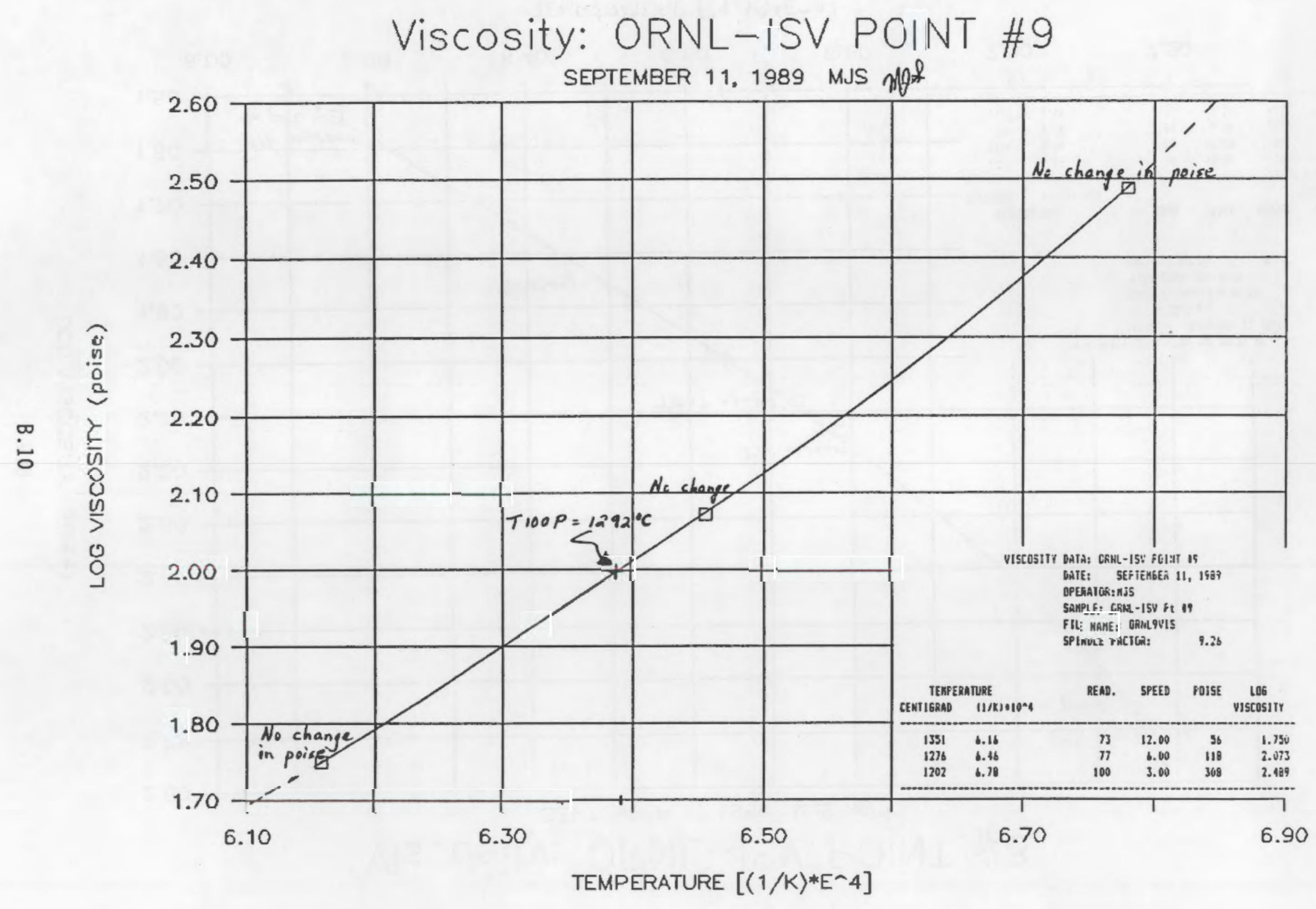




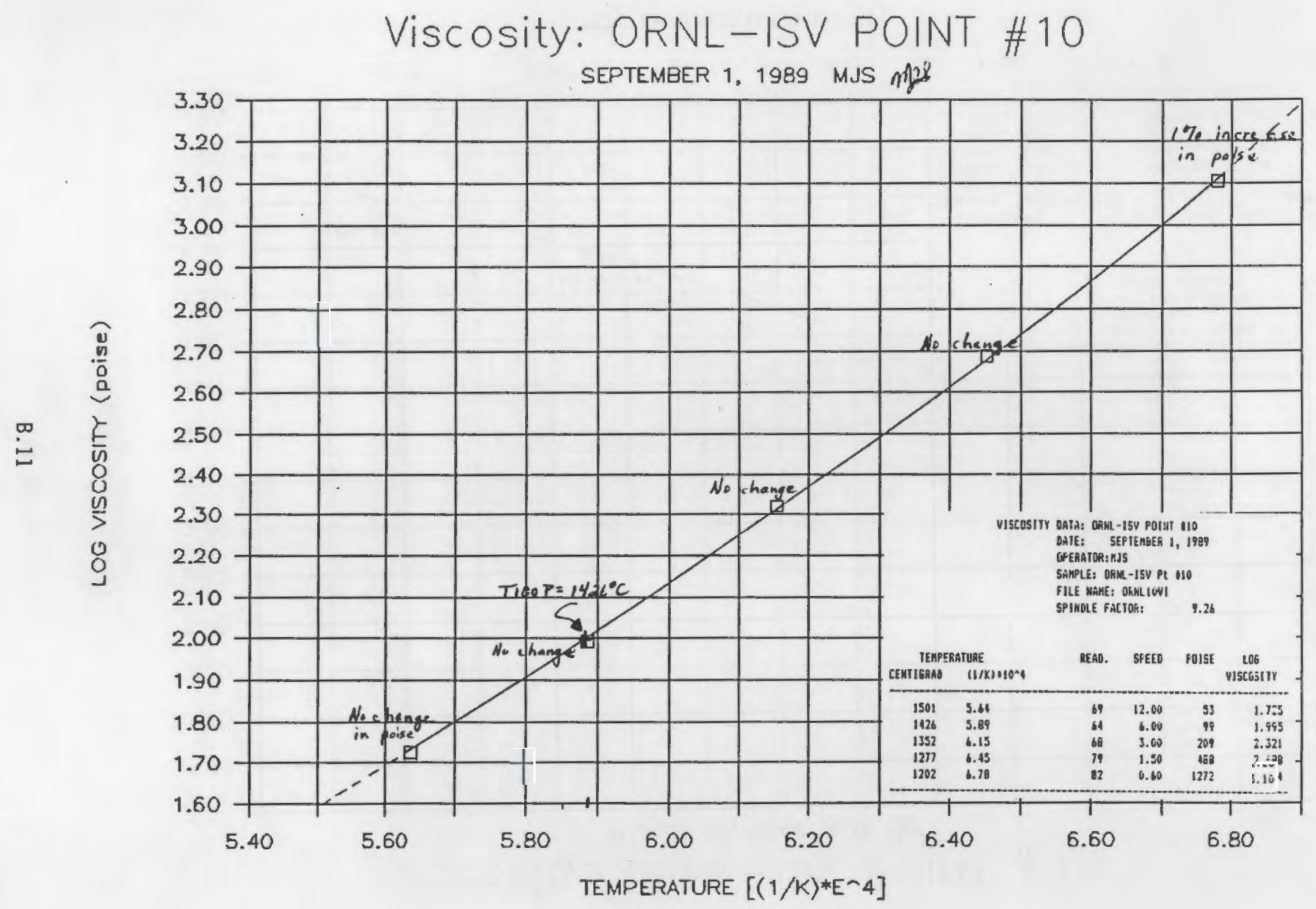




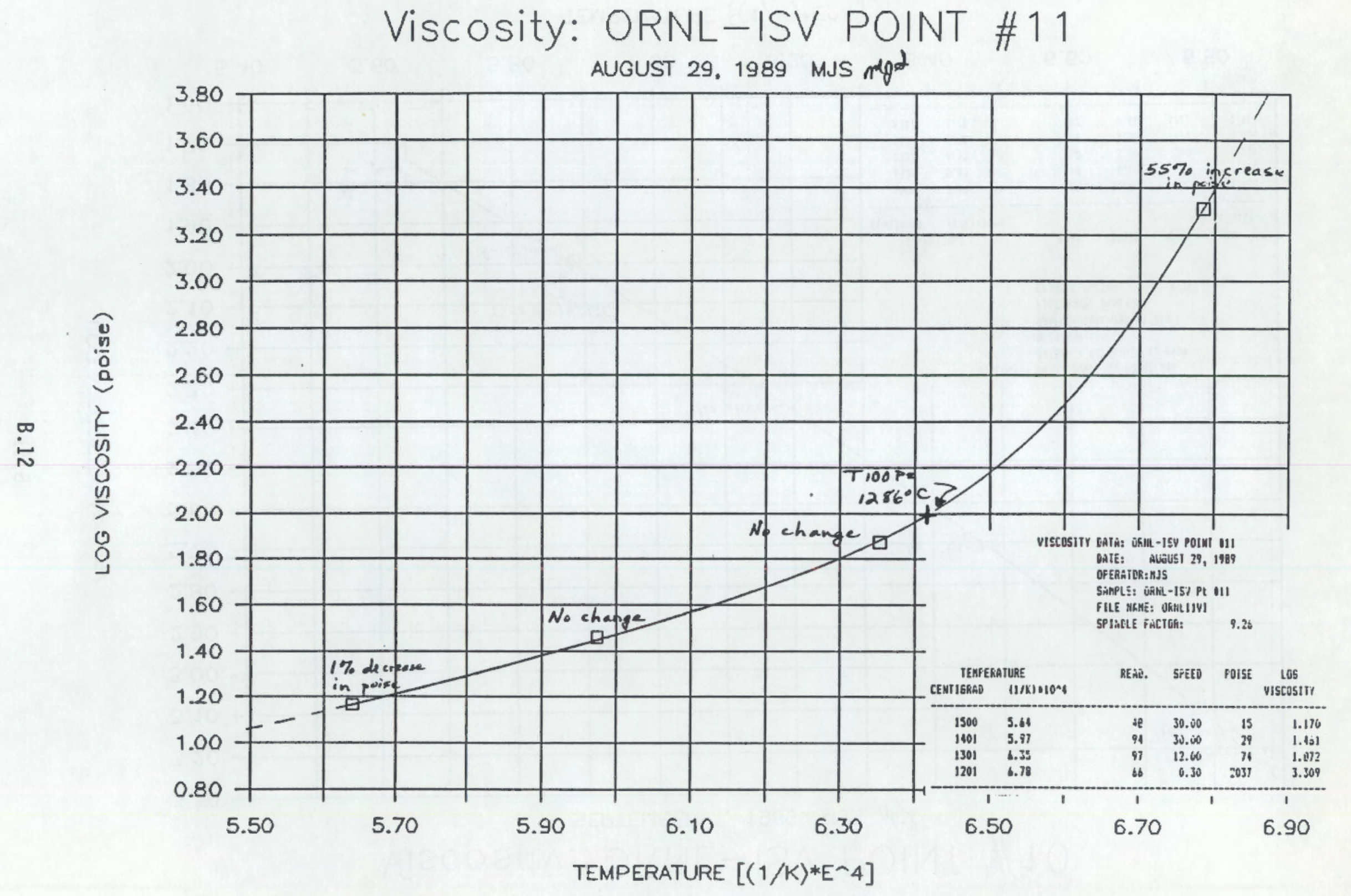




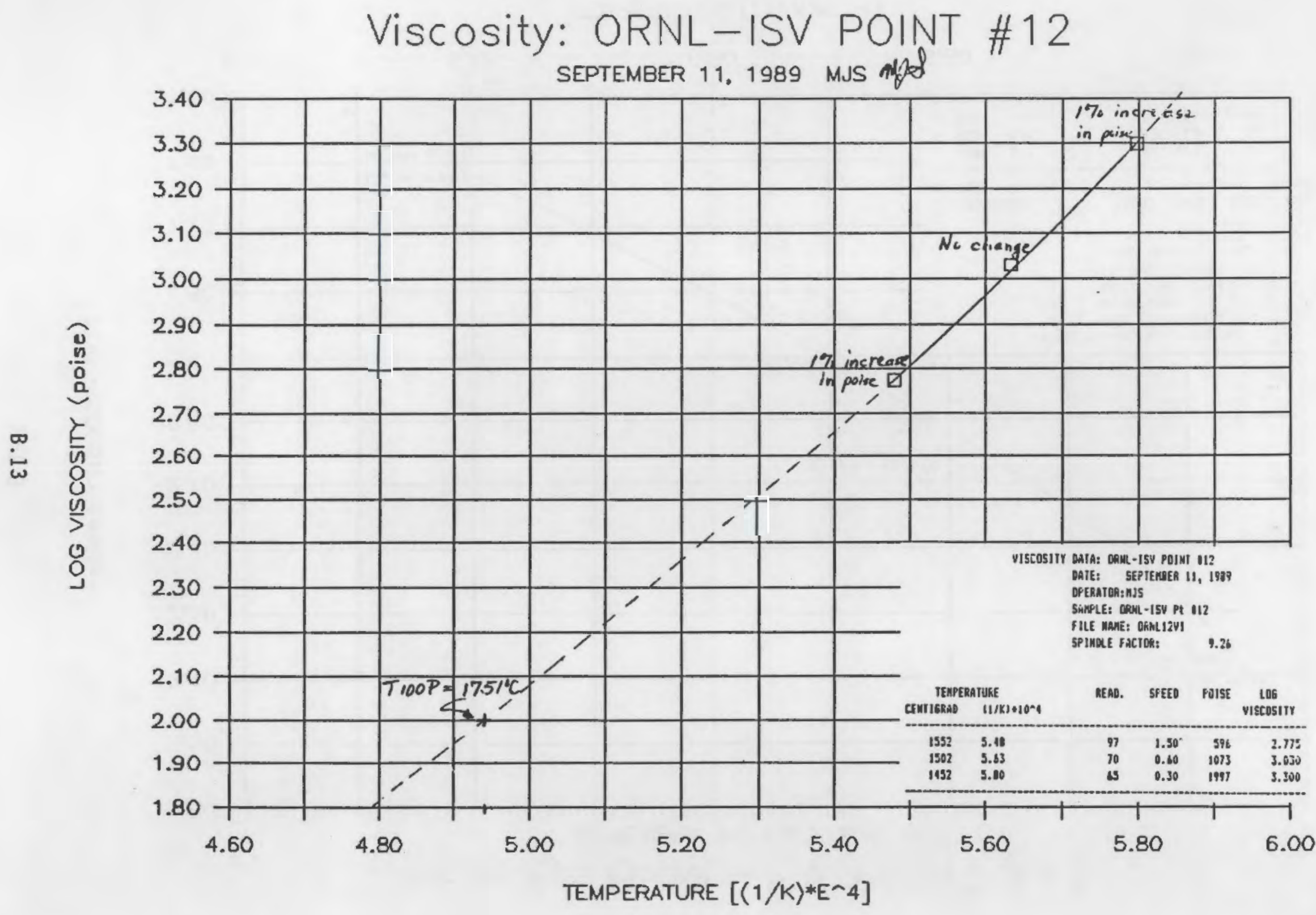




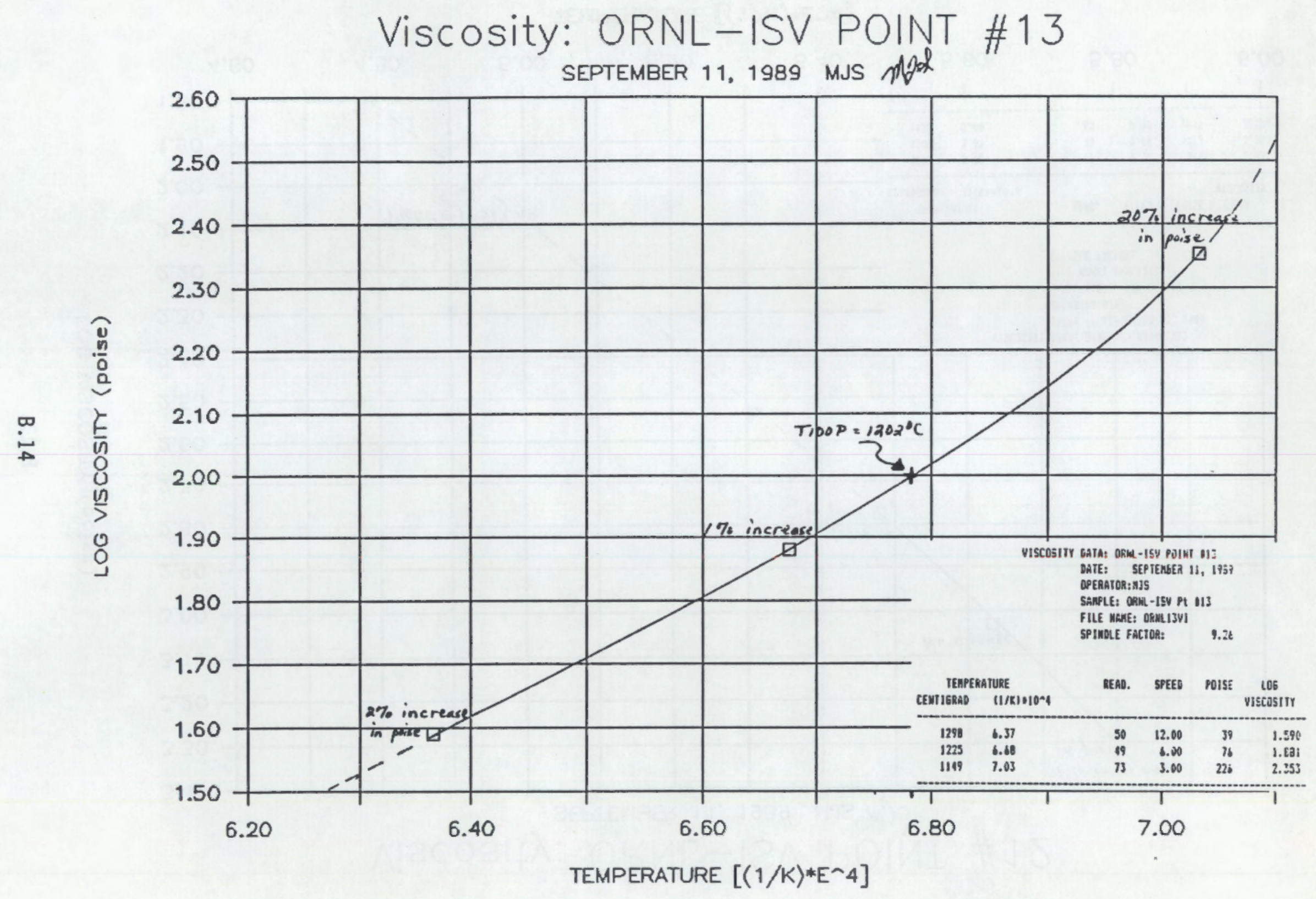




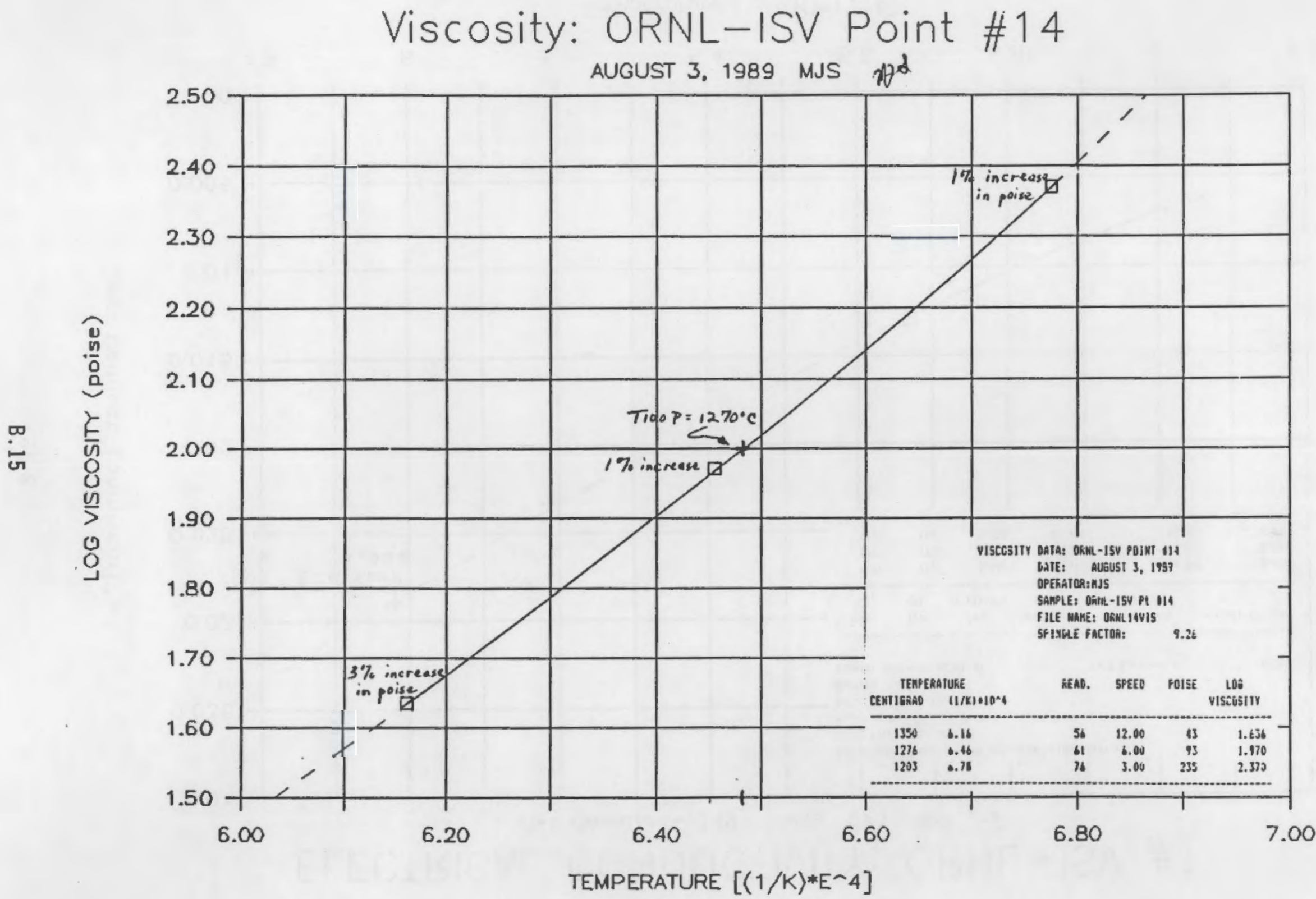




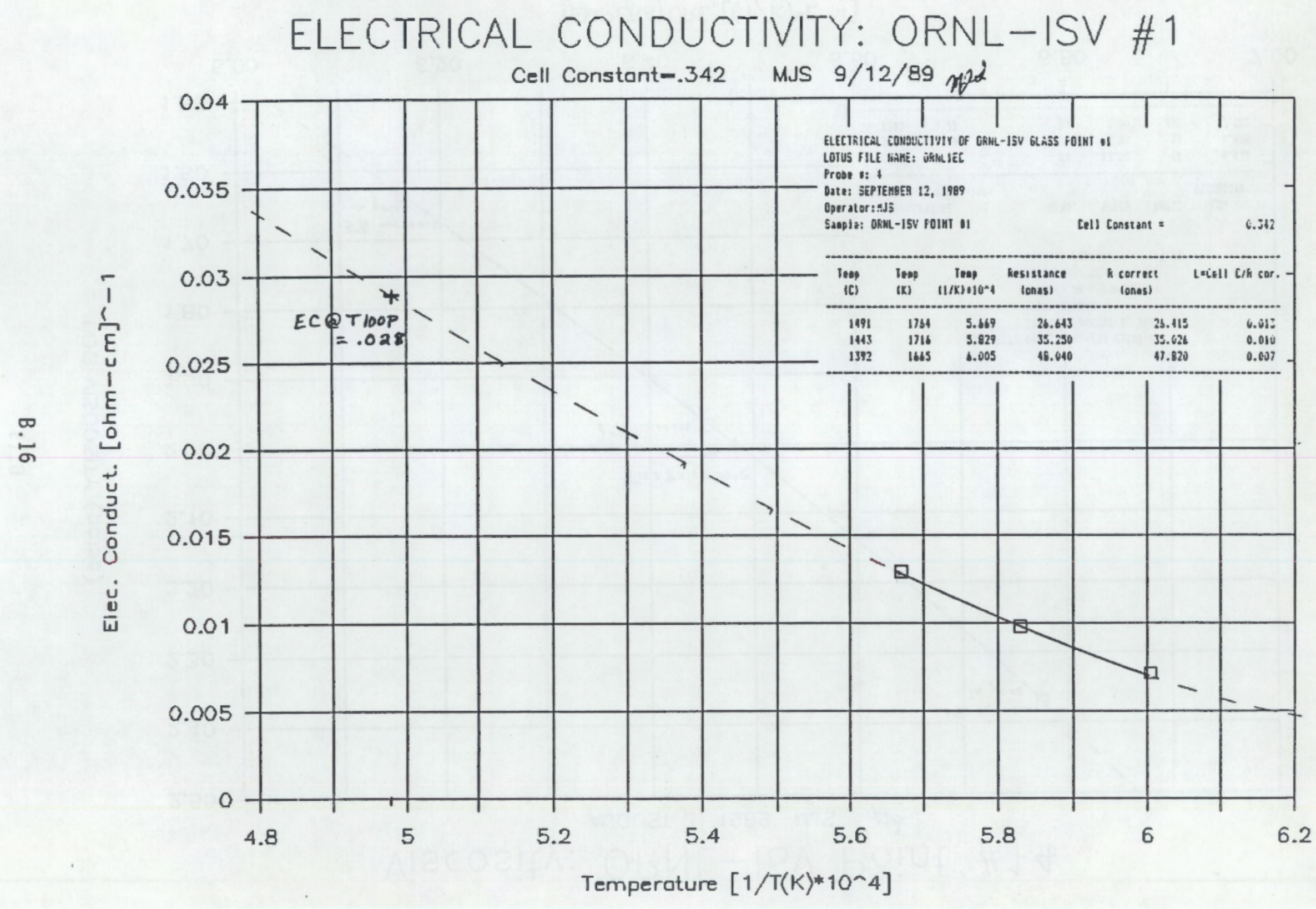


ELECTRICAL CONDUCTIVITY: ORNL-ISV \#2

Cell Constant -.342 MJS $9 / 12 / 89{ }^{2} 9^{2}$

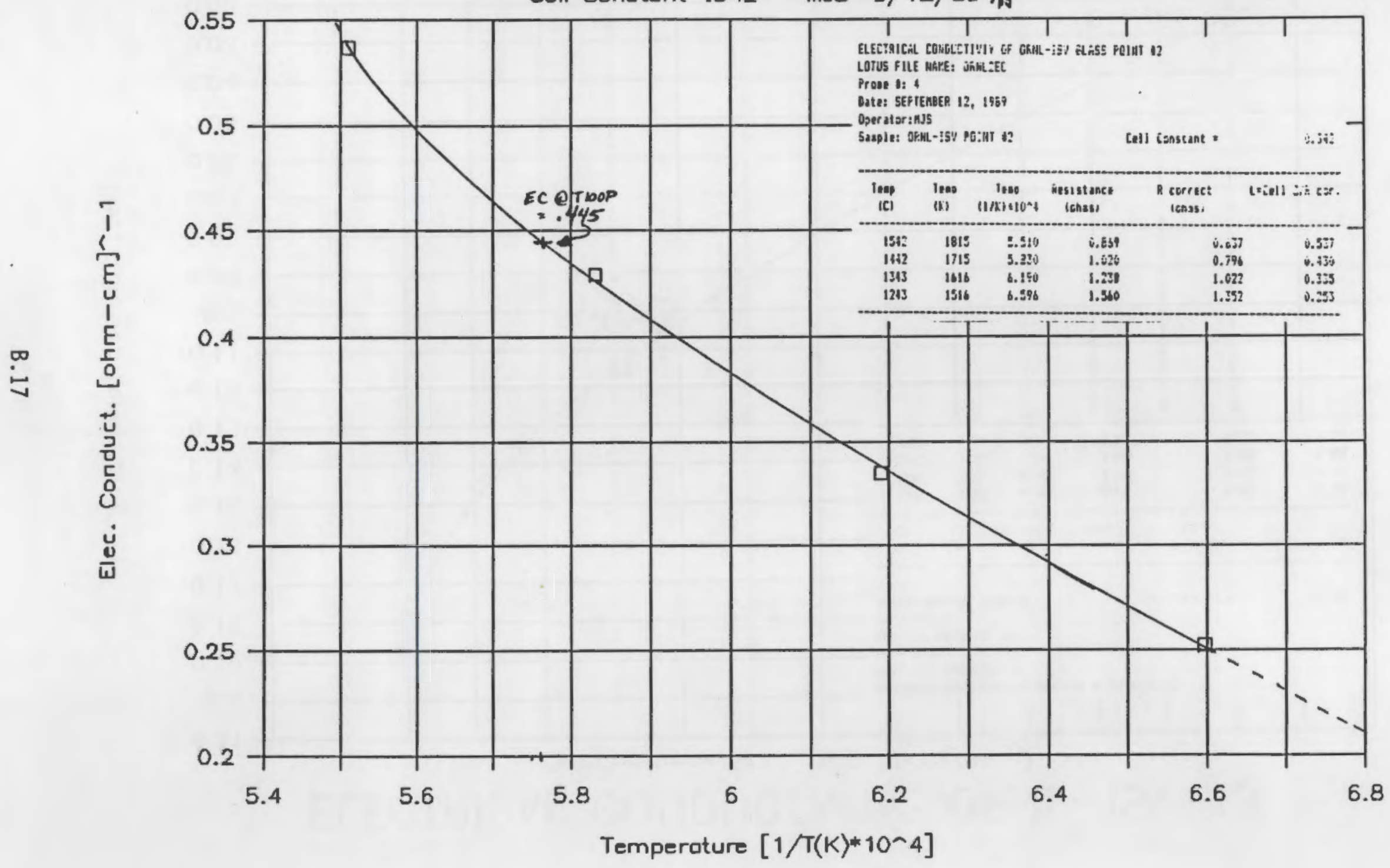


ELECTRICAL CONDUCTIVITY: ORNL-ISV \#3

Cell Constant-.342 MJS $9 / 12 / 89$ xyd

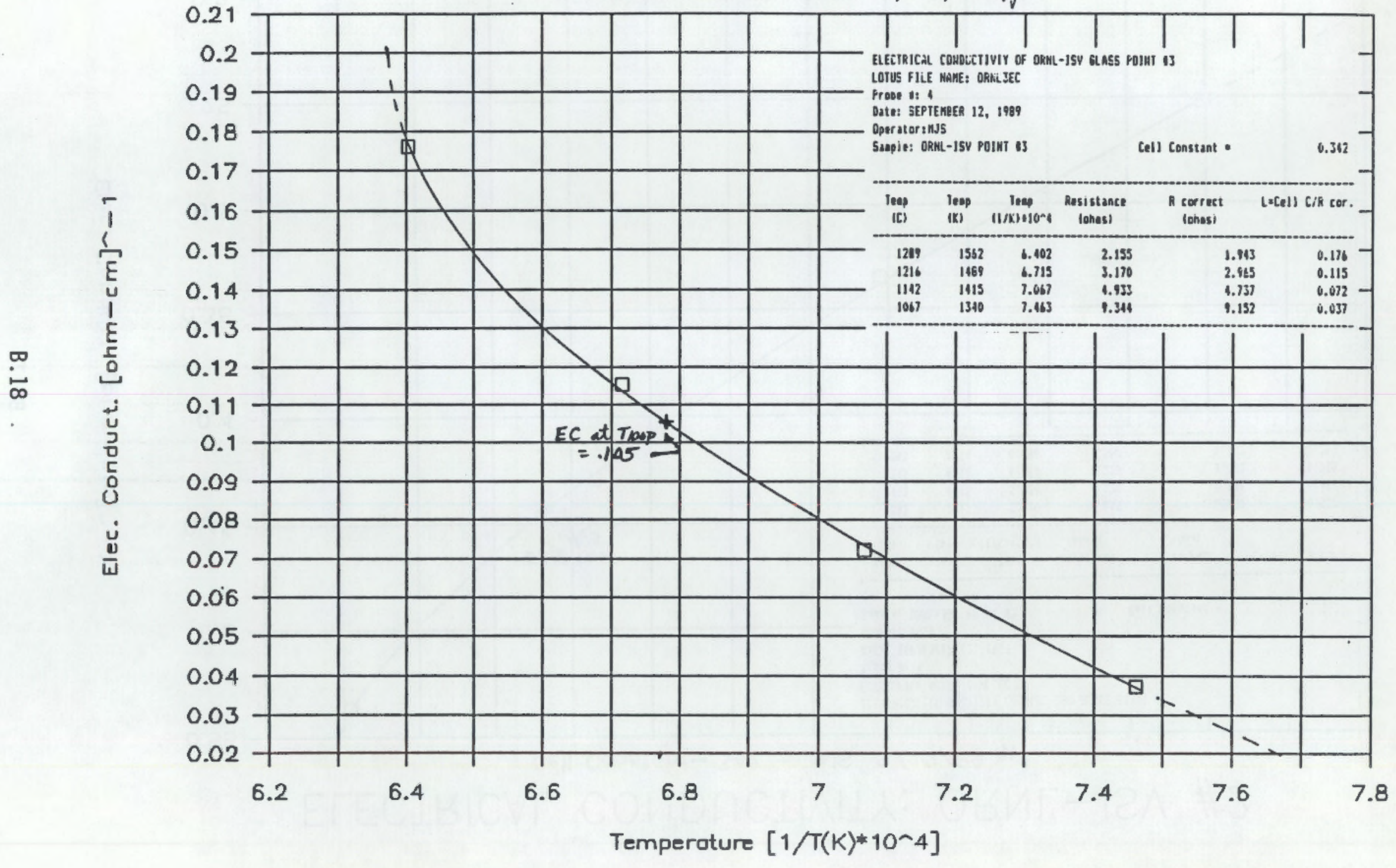




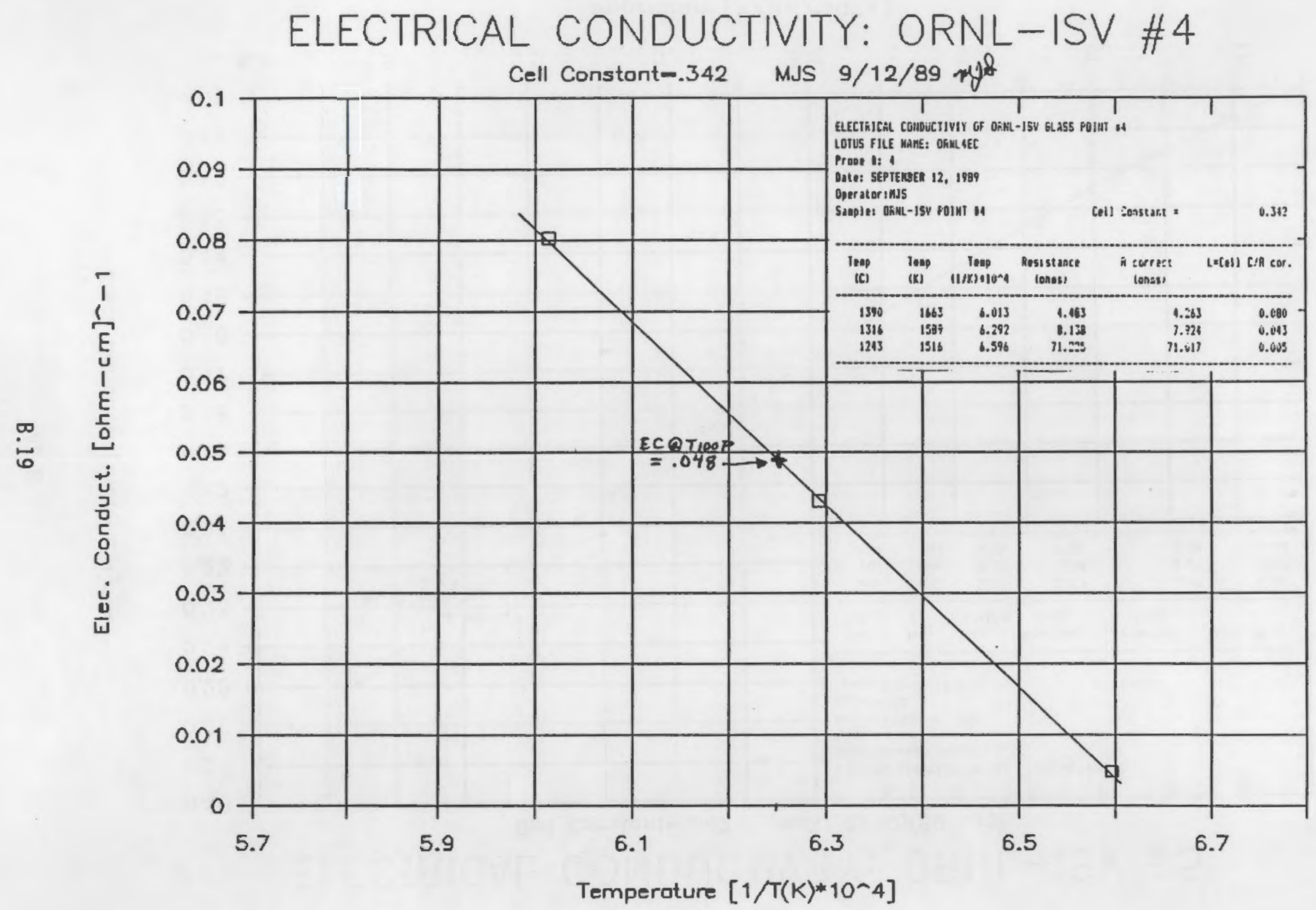




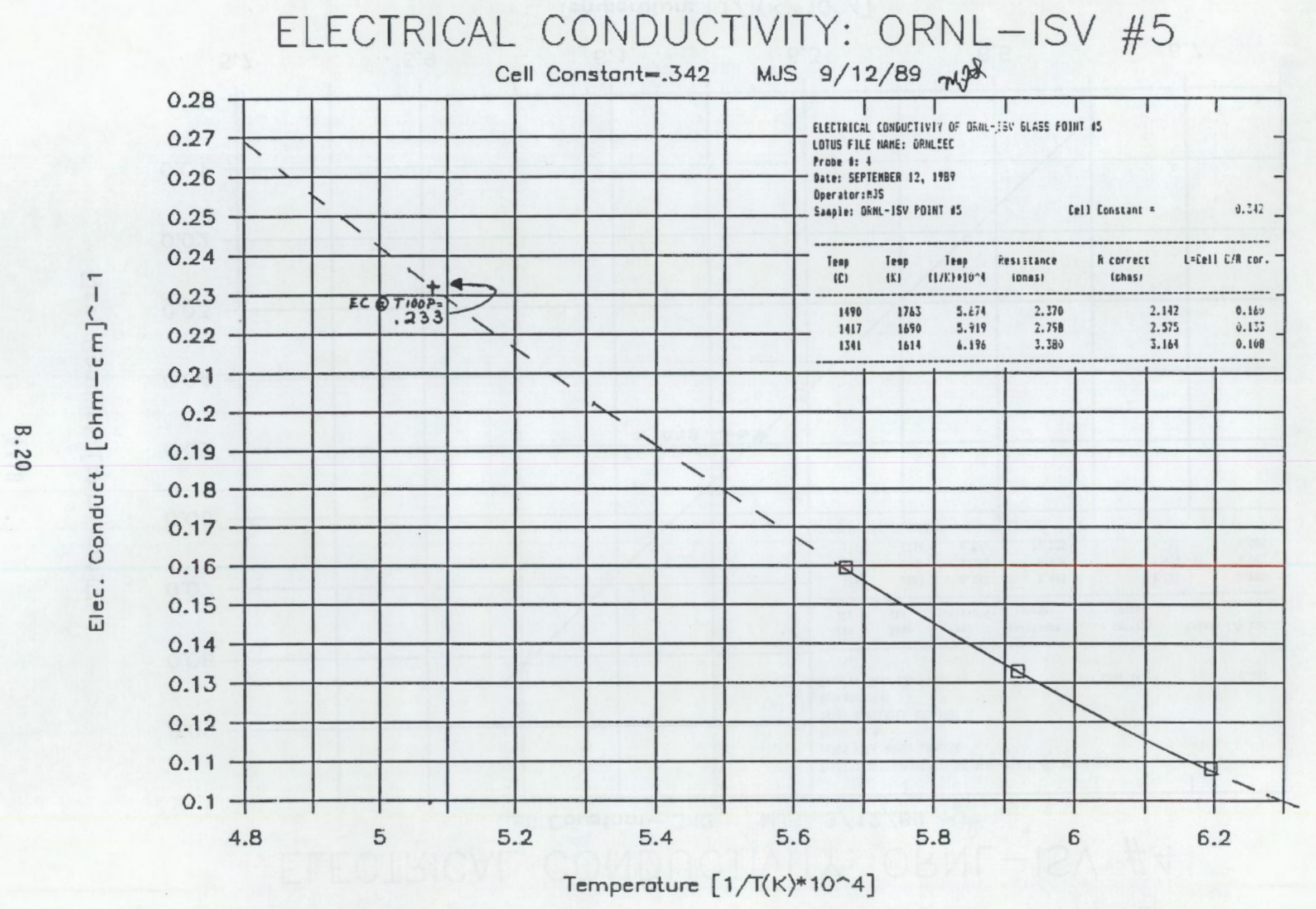




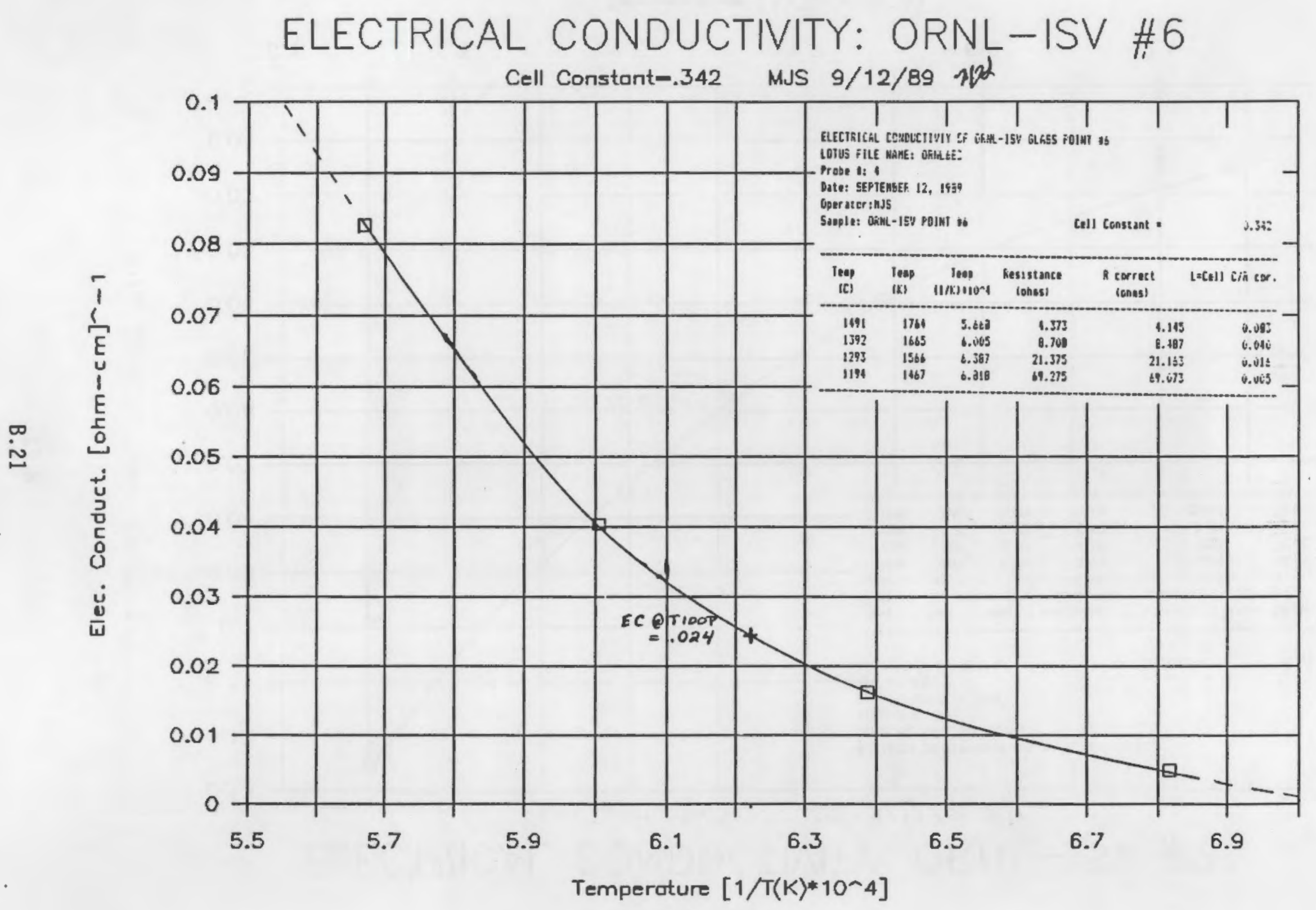


ELECTRICAL CONDUCTIVITY: ORNL-ISV \#7 Cell Constant=.342 MJS $9 / 11 / 89 \mathrm{nifl}$

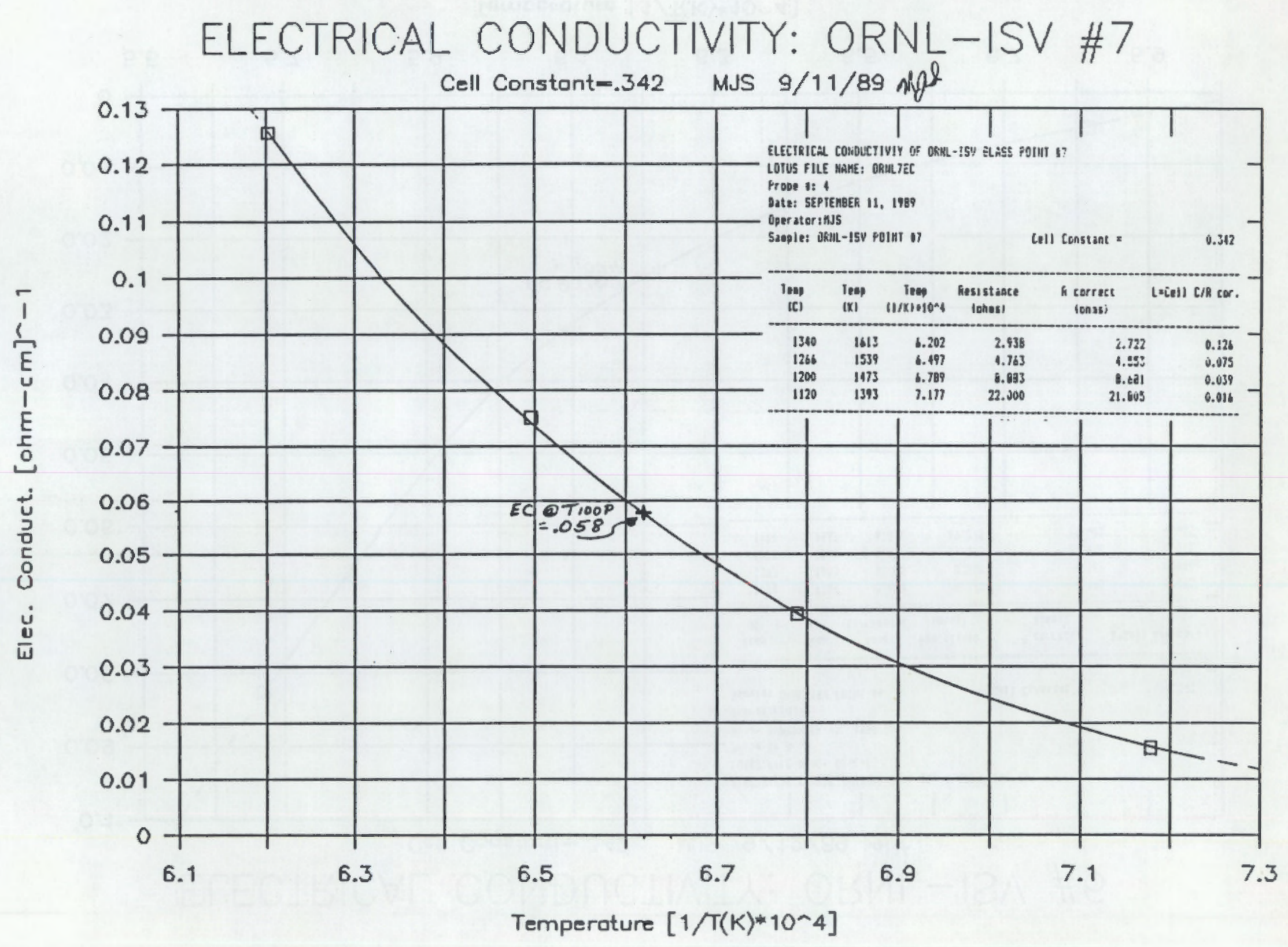




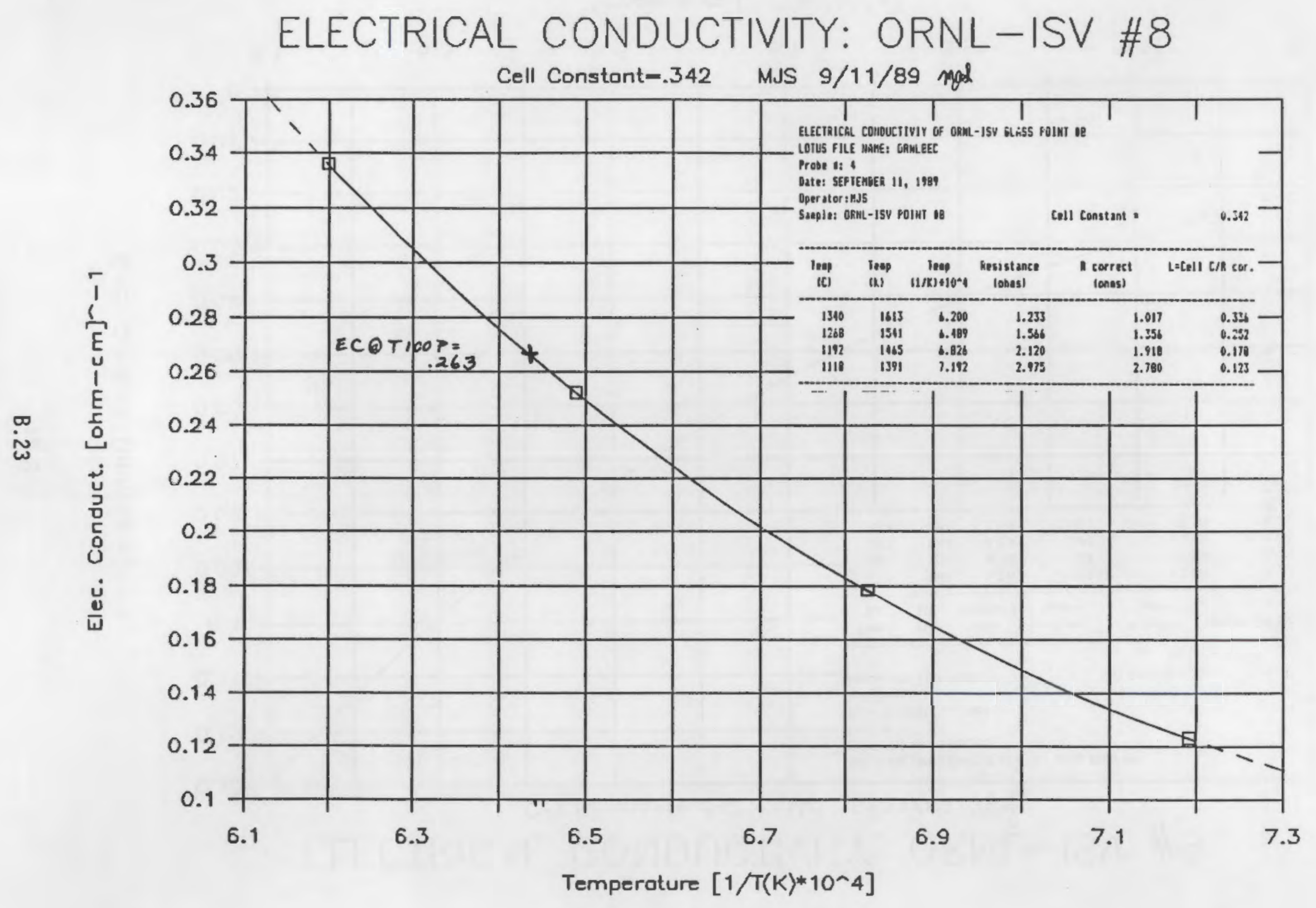




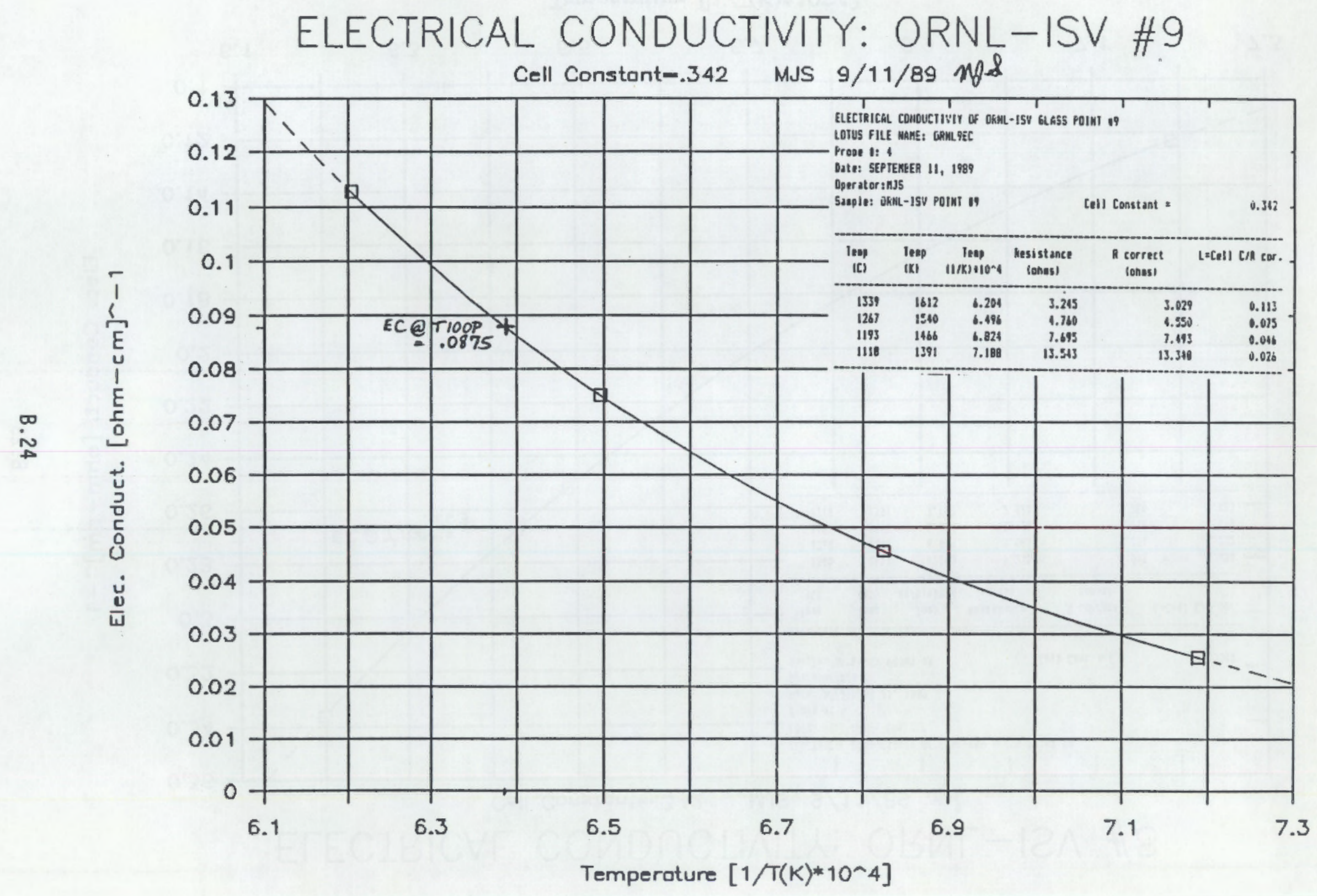


ELECTRICAL CONDUCTIVITY: ORNL-ISV \#10 Cell Constant $=.342$ MJS $9 / 12 / 89$ myd

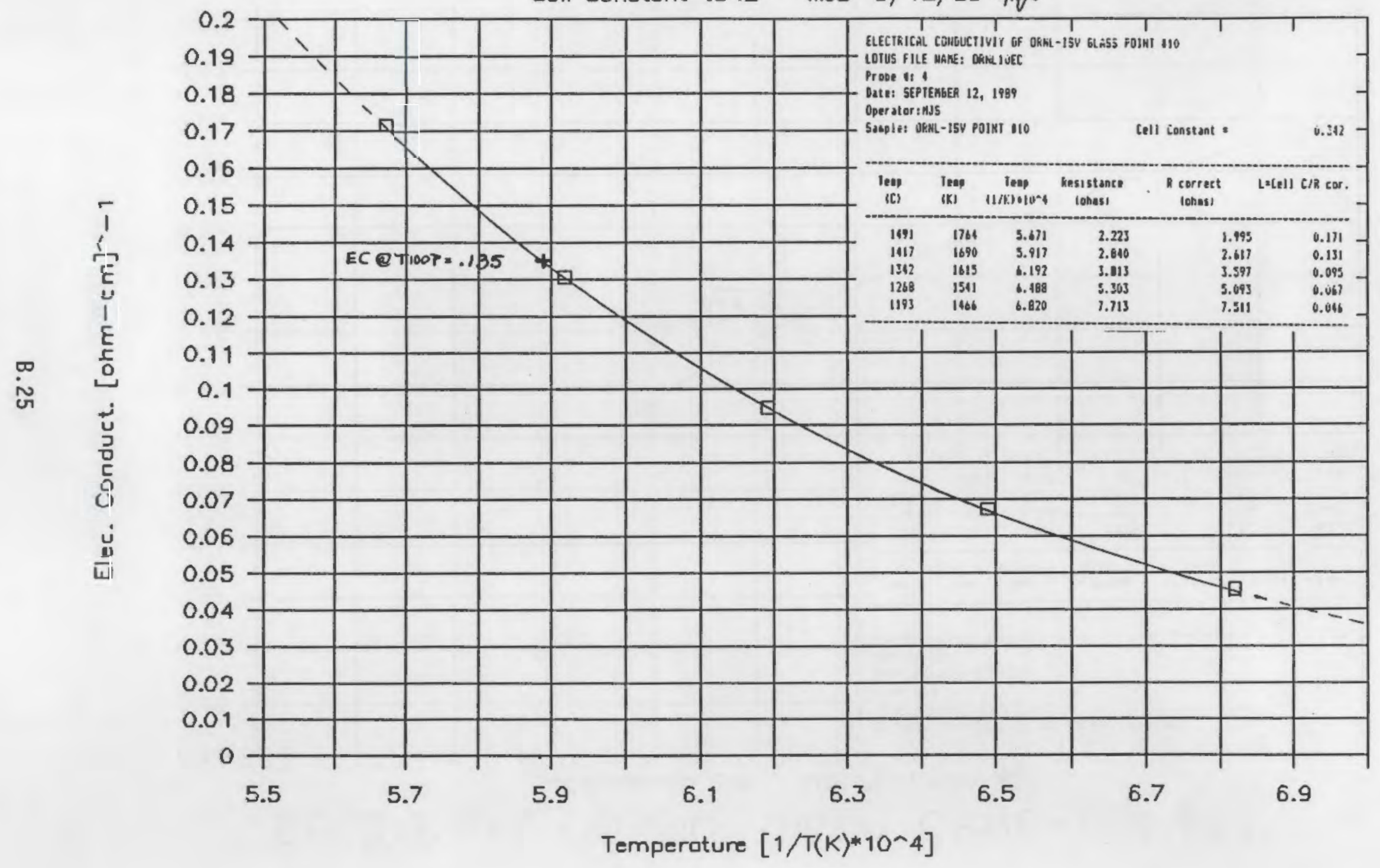




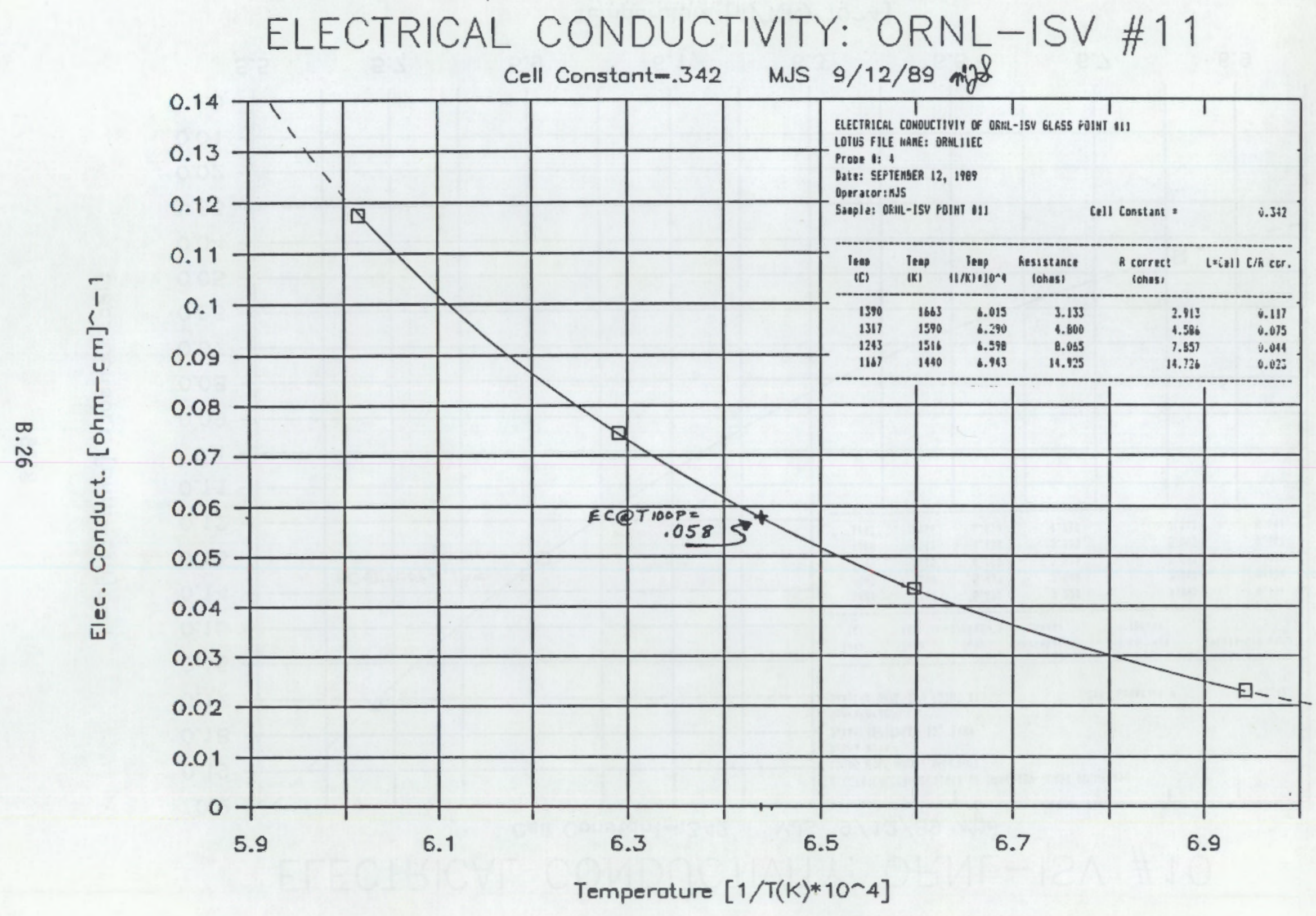




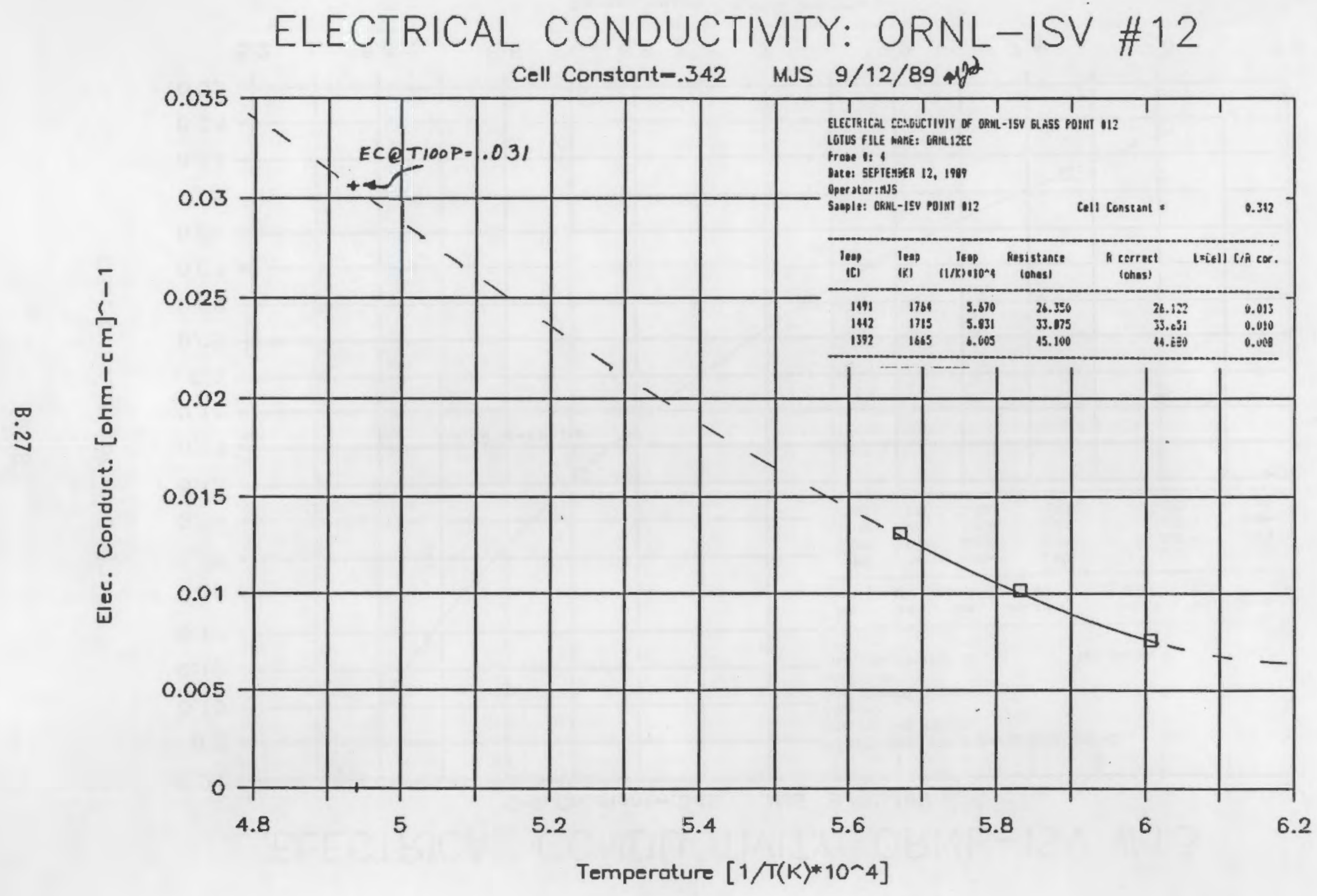




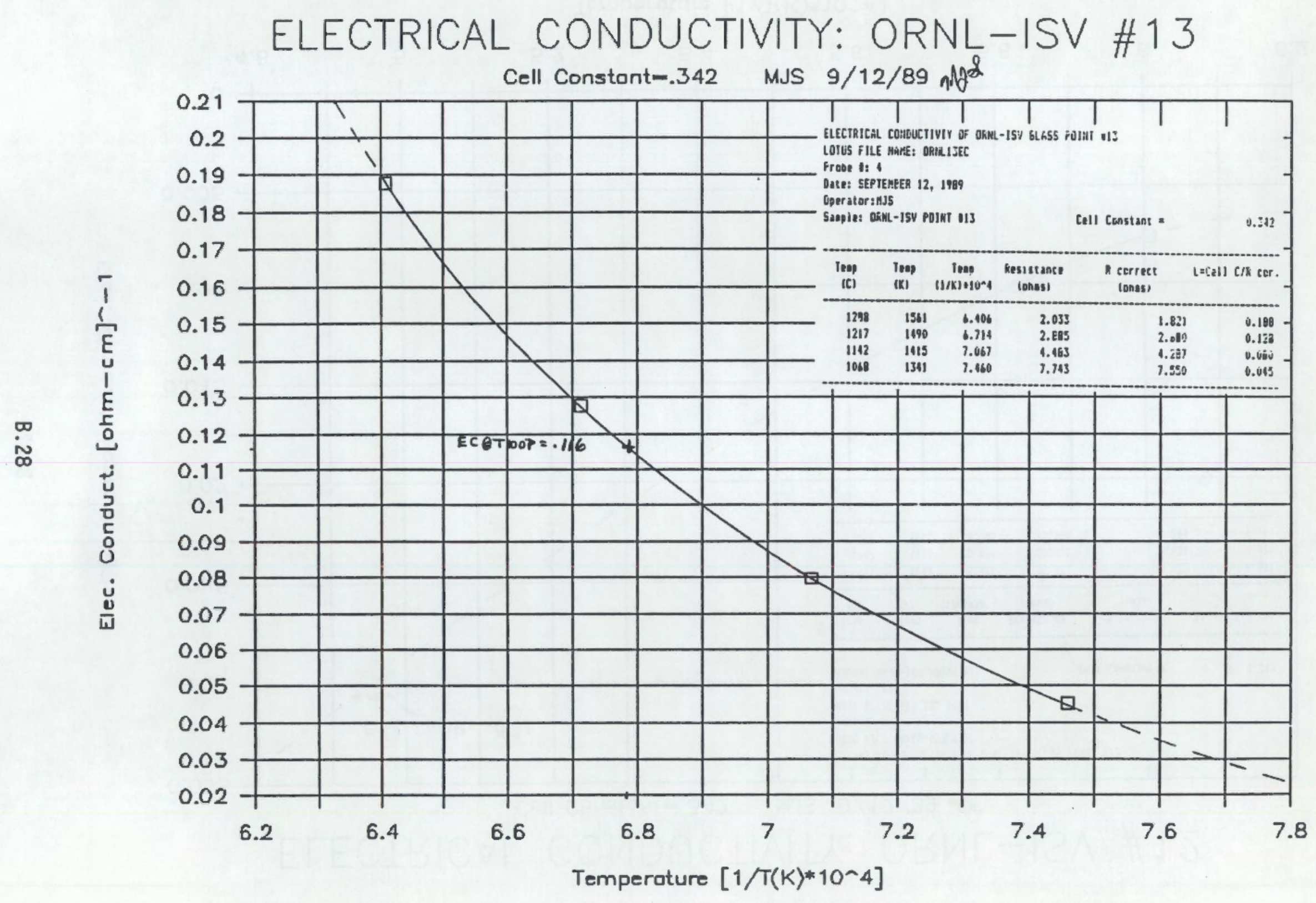




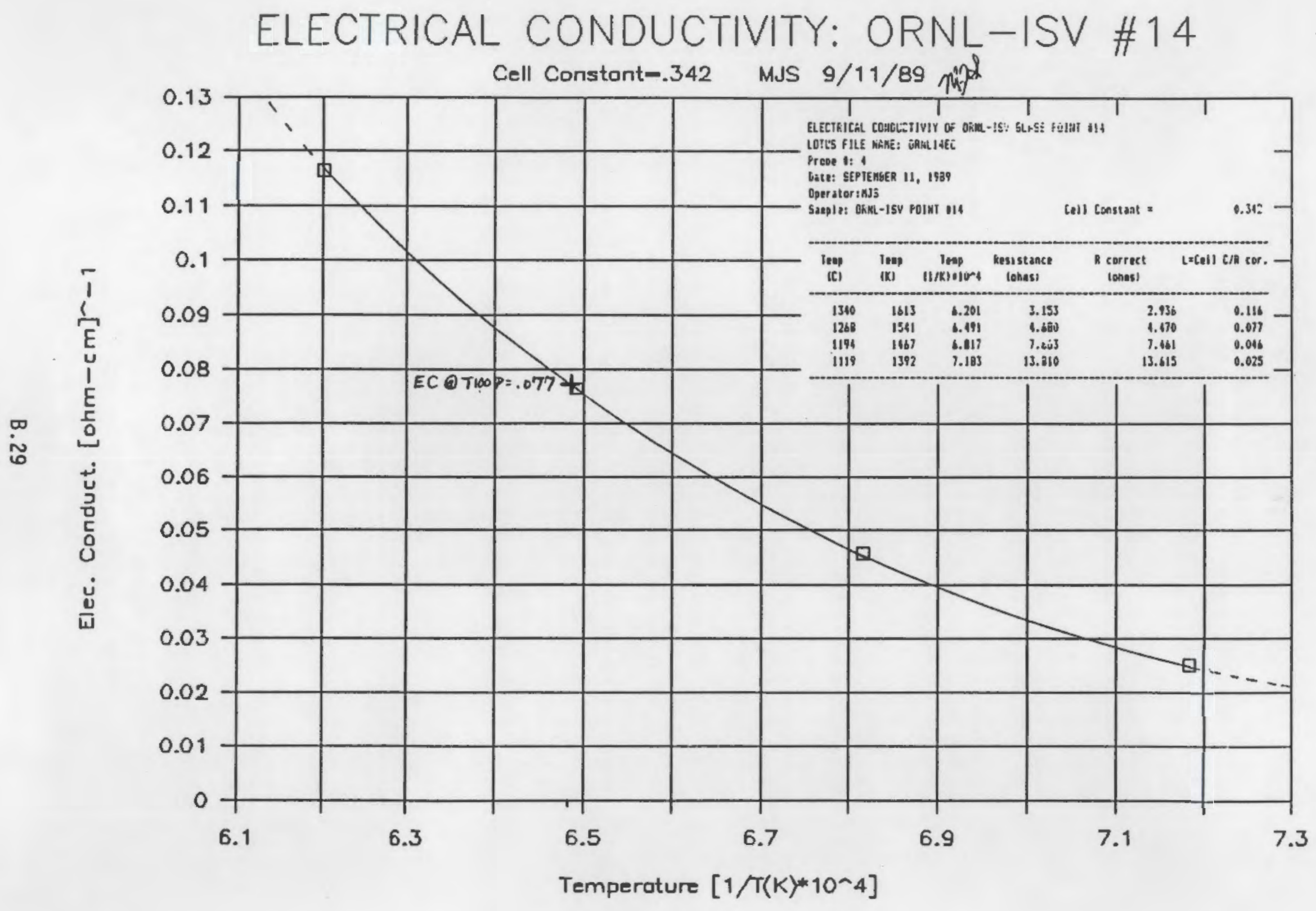


.

. 


\section{APPENDIX C}

\section{PREDICTION STANDARD DEVIATIONS AND CONFIDENCE INTERVALS FOR PREDICTIONS FROM QUADRATIC SCHEFFE MIXTURE MODELS}


APPENDIX C

\section{PREDICTION STANDARD DEVIATIONS AND CONFIDENCE INTERVALS FOR PREDICTIONS FROM QUADRATIC SCHEFFE MIXTURE MODELS}

Formulas are presented for computing standard deviations and confidence intervals for predictions made using the fitted quadratic Scheffé mixture models given in this report. A predicted value of a property for a specified composition may be thought of either as a prediction of the mean property response or as a prediction of a single measured property value that might be seen at a given composition. The standard deviation of the latter is greater than that of the former, because of the added variability of individual property observations.

Let soil, $\mathrm{CaO}$, and $\mathrm{Na}_{2} \mathrm{O}$ represent weight fractions of the components in a mixture within the region of Figure 1 . Let the $14 \times 6$ matrix $U$ consist of columns corresponding to soil, $\mathrm{Ca} 0, \mathrm{Na}_{2} \mathrm{O}$, soil - $\mathrm{CaO}$, soil $\cdot \mathrm{Na}_{2} \mathrm{O}$, and $\mathrm{CaO} \cdot \mathrm{Na}_{2} \mathrm{O}$, and rows corresponding to the 14 compositions in the test matrix shown in Table 1 . Next, let the $1 \times 6$ vector $\mathbf{u}^{\prime}$ have columns corresponding to the columns in $\mathbf{U}$ for any composition in the region displayed in Figure 1. Finally, let $\hat{\sigma}_{y}$ denote the root mean squared error from the fitted model (which is a combined measure of model lack-of-fit and uncertainty, in units of the transformed property).

The formulas for the standard deviations corresponding to predictions of transformed properties (denoted generically as $y$ ) from the fitted quadratic scheffé mixture models are given below:

Mean Prediction

$$
\operatorname{SD}[\text { mean } y(u)]=\left[U^{\prime}\left(U^{\prime} U\right)^{-1} U\right]^{0.5} \cdot \hat{\sigma}_{y}
$$

lndividual Prediction

$$
\operatorname{SD}[\text { indiv. } y(u)]=\left[1+u^{\prime}\left(U^{\prime} U\right)^{-1} u\right]^{0.5} \cdot \hat{\sigma}_{y}
$$

C. I 
The $\left(U^{\prime} U\right)^{-1}$ matrix and the values of $\hat{\sigma}_{y}$ for each of the four properties are given in Table C.1.

As noted above, the prediction standard deviations given by Equations (C.1) and (C.2) are in transformed property units. To get the prediction standard deviations in original property units, it is necessary to apply variance propagation techniques. However, we are not directly interested in the prediction standard deviations, but rather some indication of how much the property value may differ from the predicted value. A way to do this is to compute a $95 \%$ confidence interval for the prediction in transformed property units, and then apply the inverse transformation to obtain a 95\% confidence interval for the prediction in original property units.

The formulas for $95 \%$ confidence intervals corresponding to predictions of transformed properties (denoted generically as $y$ ) from the fitted quadratic Scheffé mixture models are given below.:

Hean Prediction

$$
\mathrm{CI}[\text { mean } \mathrm{y}(u)]=\hat{\mathrm{y}}(\mathbf{u}) \pm 2.306 \cdot \operatorname{SD}[\text { mean } \mathrm{y}(u)]
$$

Individual Prediction

$$
\text { CI [indiv. } y(u)]=\hat{y}(u) \pm 2.306 \cdot \operatorname{SD}[\text { indiv. } y(u)]
$$

The 2.306 value is from a $t$-distribution and provides the required $95 \%$ confidence for the fitted models in this report. The $95 \%$ confidence intervals (mean or individual) on a prediction in original property units are obtained by applying the inverse property transformation to the lower and upper endpoints of the confidence interval. 
TABLE C.1. The $\left(U^{\prime} U\right)^{-1}$ Matrix and the Values of $\hat{\sigma}_{y}$ for
Each of the Four Properties $\left(U^{\prime} U\right)^{-1}=\left|\begin{array}{rrrrrr}0.4552 & 0.5312 & 9.8000 & -2.0066 & -14.8020 & -7.2275 \\ 0.5312 & 53.3146 & -169.1149 & -93.0570 & 205.6012 & 146.0427 \\ 9.8000 & -169.1149 & 7625.8403 & 376.8661 & -8872.4600 & -9036.3701 \\ -2.0066 & -93.0570 & 376.8661 & 174.4328 & -445.6859 & -399.8534 \\ -14.8020 & 205.6012 & -8872.4600 & -445.6859 & 10388.9121 & 10406.7979 \\ -7.2275 & 146.0427 & -9036.3701 & -399.8534 & 10406.7979 & 11192.3584\end{array}\right|$

\begin{tabular}{|c|c|c|}
\hline Property & Transformed Property & $\hat{\sigma}_{y}$ \\
\hline $\mathrm{T} 100 \mathrm{P}$ & $1 / \mathrm{T} 100 \mathrm{P}$ & $0.155634 \mathrm{E}-04$ \\
\hline ECT100P & $(E C T 100 P)^{\star \star} 0.5$ & $0.235682 E-01$ \\
\hline V1330 & $\ln (v 1330)$ & $0.508626 \mathrm{E}+00$ \\
\hline EC1330 & $(E C 1330)^{\star \star} 0.5$ & $0.210607 E-01$ \\
\hline
\end{tabular}




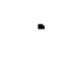




\section{DISTRIBUTION}

No. of

Copies

OFFSITE

12 DOE/Office of Scientific and Technical Information

T. B. Hindman, DP-12 DOE Office of Defense Programs GTN Washington, DC 20545

H. F, Wa]ter, EM-343 DOE Office of Waste Operations GTN

Washington, DC 20545

5 DOE Office of Environmental

Restoration and Waste Management Forrestal Building Washington, DC 20585

ATTN: C. R. Cooley, EM-55

T. 0. Anderson, EM-442

C. Frank, EM-50

S. Prestwich, EM-52

S. P. Mathur, EM-54

J. Arthur

DOE Albuquerque Operations Office

P.0. Box 5400

Albuquerque, NM 87185

E. Maestas

DOE West Valley Project

P.0. Box 191

West Valiey, NY 14171

3 DOE Idaho Operations office

785 DOE P1 ace

Idaho Falls, ID 83402

ATTN: J. P. Hamric

M. W. Shupe

S. A. Morreale
No. of

Copies

W. T. Goldston

DOE Savannah River Operations Office

P.0. Box A

Aiken, SC 29801

M. J. Steindler, CMT-205

Argonne National Laboratory

9700 South Cass Avenue

Argonne, IL 60439

2 Battelle Memorial Institute

505 King Avenue

Columbus, $\mathrm{OH} 43201$

ATTN: W. A. Carbeiner

R. A. Nathan

L. D. Ramspott, L209

Lawrence Livermore National Laboratory

University of California

P.0. Box 808

Livermore, CA 94550

M.A.H. Reimus

Los Alamos National Laboratory

P.0. Box 1663

Los Alamos, NM 87545

4 Oak Ridge National Laboratory

P.0. Box Y

Oak Ridge, TN 37830

ATTN: G. K. Jacobs

L. J. Mezga

T. A. Row

B. P. Spalding

5

EG\&G Idaho

P.0. Box 1625

Idaho Falls, ID 83415

ATTN: S. 0. 8ates

B. L. Charboneau

J. L. Landon

R. M. Schletter

J. R. Weidner 
No. of

Copies

2 Sandia Laboratories

P.0. Box 5800

Albuquerque, NM 87185

ATTN: R. W. Lynch

Technical Library

J. R. Berreth

Westinghouse Idaho Nuclear

Co., Inc.

P.0. Box 4000

Idaho Falls, ID 83401

5 Westinghouse Savannah River Company Aiken, SC 29801

ATTN: R. G. Baxter

J. Haselow

C. M. Jantzen

M. J. Plodinec

J. Steele

J. M. Pope

West Valley Nuclear Services Co. P.0. Box 191

West Valley, NY 14171

3 Geosafe Corporation

Kirkland Park Place

303 Park Place, Suite 126

Kirkland, WA 98033

ATTN: V. F. FitzPatrick

C. L. Timmerman

J. G. Carter

\section{ONSITE}

8 DOE Richland Operations Office

E. A. Bracken, A6-95

G. J. Bracken, $A 6-B 0$

P. K. Clark, $A 6-80$

P. F. Dunigan, A6-95

M. J. Furman, $A 6-80$

R. E. Gerton, $A 6-80$

R. D. Izatt, $A 6-95$

J. J. Sutey, A5-90
No. of

Copies

10 Westinghouse Hanford Company

J. W. Cammann, H4-54

K. R. Fecht, $\mathrm{H4}-56$

R. E. Lerch, B2-35

H. E. McGuire, B2-35

J. L. Scott, R2-87

J. C. Sonnichsen, H4-54

D. A. Turner, Rl-10

D. D. Wodrich, R1-48

R. D. Wojtasek, B2-15

B. A. Wolfe, L5-61

39 Pacific Northwest Laboratory

C. E. Bigelow, P7-44

W. F. Bonner, P7-44

T. M. Brouns, P7-44

J. L. Buelt, P7-44

H. C. Burkholder, P7-41

B. E. Campbe11, P7-44

C. C. Chapman, P7-41

R. K. Farnsworth, P7-44

R. D. Gibby, P7-44

C. H. Kindle, P7-44

D. E. Knowlton, P7-40

S. S. Koegler, P7-44

J. L. McElroy, P7-46

K. A. Parne11, P7-14

M. E. Peterson, P7-44

G. F. Piepel (5), K1-86

T. D. Powe 11, P7-44

J. W. Shade $(10), P 8-37$

J. A. Stottlemyre, K6-78

L. E. Thompson, P7-44

Publishing Coordination

Technical Report Files (5) 